Scientific Publications of the American Museum of Natural History

AMERICAN MUSEUM NOVITATES

Bulletin of the American Museum of Natural History

Anthropological Papers of the American Museum of Natural History

Publications Committee

ROBERT S. VOSS, ChAIR

BOARD OF EDITORS

JiN MenG, PALEONTOLOGY

LORENZO PRENDINI, INVERTEBRATE ZOOLOGY

ROBERT S. VOSS, VERTEBRATE ZOOLOCY

Peter M. Whiteley, ANTHROPOLOGY

MANAGING EDITOR

MARY KNIGHT

Submission procedures can be found at http://research.amnh.org/scipubs

All issues of Novitates and Bulletin are available on the web (http://digitallibrary.amnh. org/dspace). Order printed copies on the web from:

http://shop.amnh.org/a701/shop-by-category/books/scientific-publications.html or via standard mail from:

American Museum of Natural History—Scientific Publications

Central Park West at 79th Street

New York, NY 10024

@ This paper meets the requirements of ANSI/NISO Z39.48-1992 (permanence of paper).

ON THE COVER: UPPER IMAGE: THE SHRIMP AlPHEUS MICROSTYlus (BATE, 1888) (AlPheidae) INFESTED Ventrally by THE ABDOMINAL BOPYRID PARASITE EOPHRIXUS CAUDATUS, N. SP. LOWER IMAGE: E. CAUDATUS, N. SP., MALE (LEFT) AND FEMALE (RIGHT).
A REVIEW OF BOPYRIDS (CRUSTACEA: ISOPODA: BOPYRIDAE) PARASITIC ON

CARIDEAN SHRIMPS (CRUSTACEA:

DECAPODA: CARIDEA) FROM CHINA

JIANMEI AN, CHRISTOPHER B. BOYKO, AND XINZHENG LI

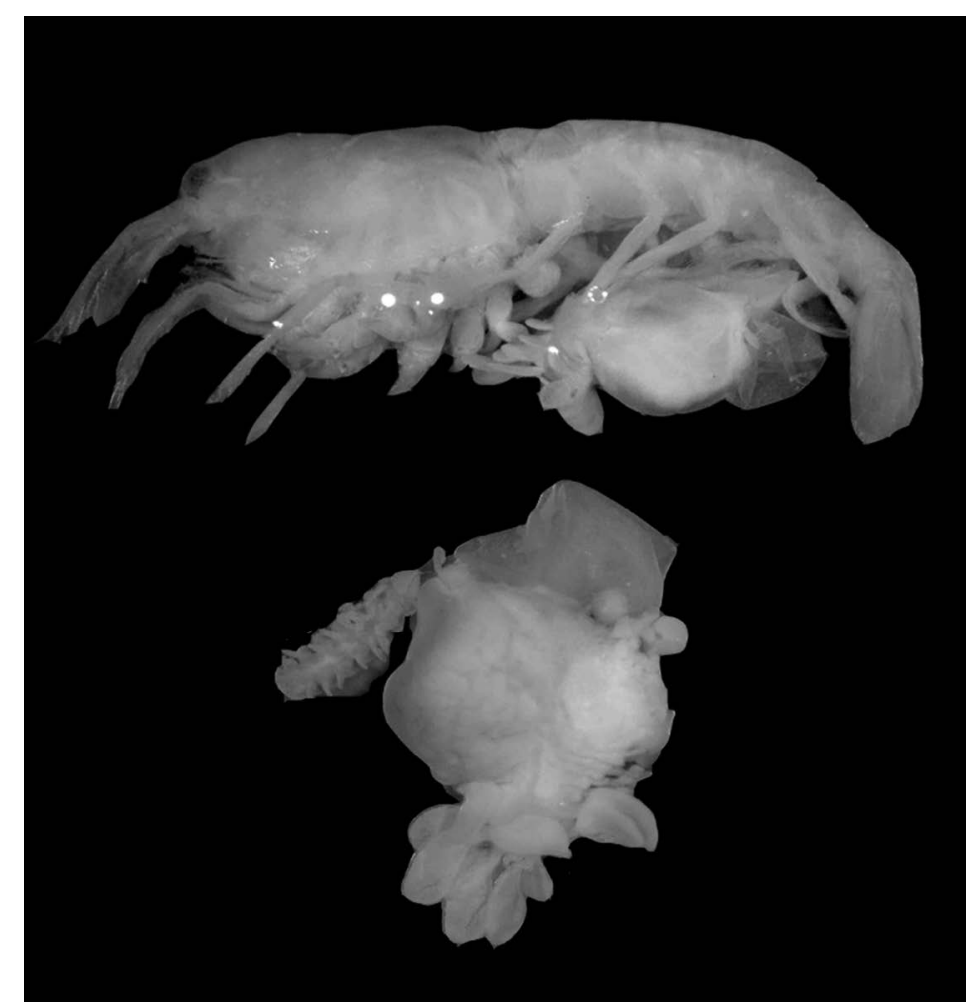




\title{
A REVIEW OF BOPYRIDS (CRUSTACEA: ISOPODA: BOPYRIDAE) PARASITIC ON CARIDEAN SHRIMPS (CRUSTACEA: DECAPODA: CARIDEA) FROM CHINA
}

\author{
JIANMEI AN \\ School of Life Science, Shanxi Normal University, Linfen, China
}

\begin{abstract}
CHRISTOPHER B. BOYKO
Department of Biology, Dowling College, Oakdale, NY; and Division of Invertebrate Zoology, American Museum of Natural History

XINZHENG LI

Institute of Oceanology, Chinese Academy of Sciences, Qingdao, China
\end{abstract}




\section{CONTENTS}

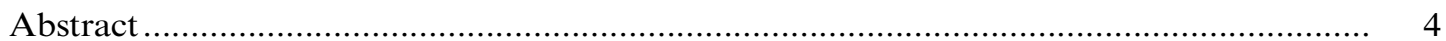

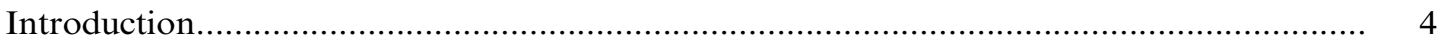

Summary List of New Taxa, Taxonomic Decisions, and Chinese Records ...................... 13

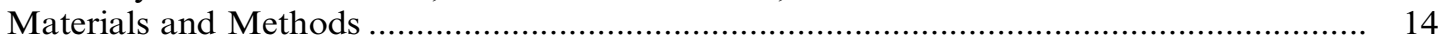

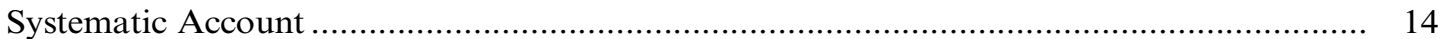

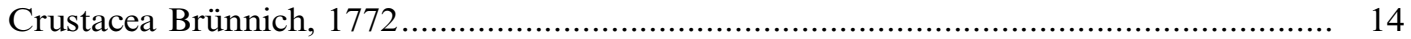

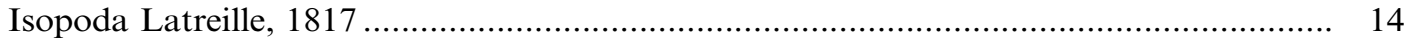

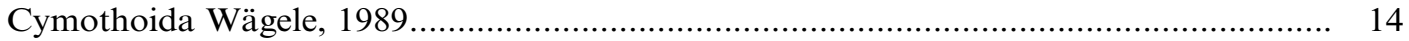

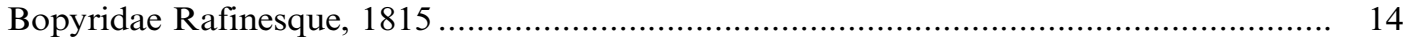

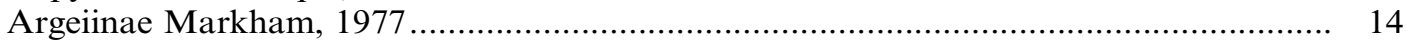

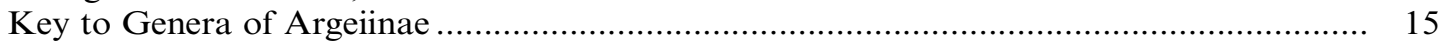

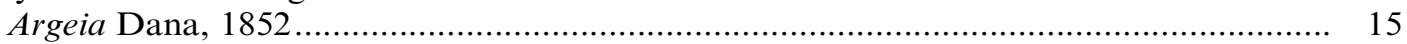

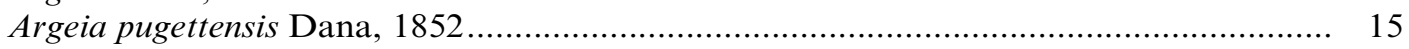

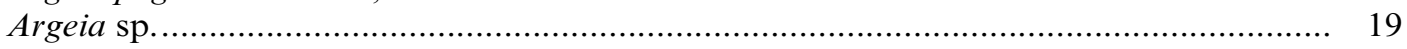

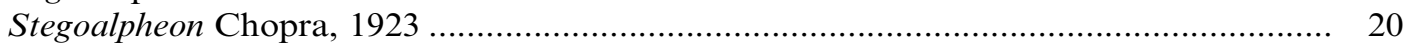

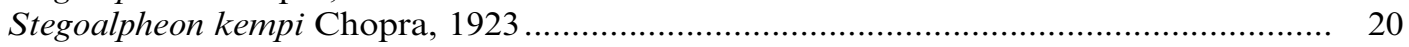

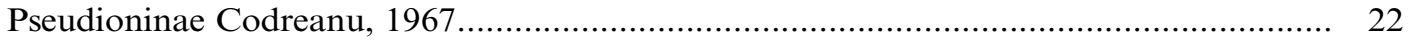

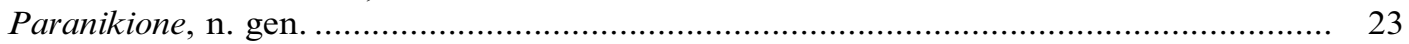

Paranikione sibogae, n. sp................................................................................ 23

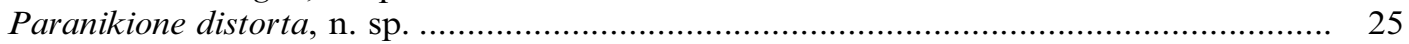

Pseudione Kossmann, 1881 .................................................................................. 27

Pseudione tattersalli Nierstrasz and Brender à Brandis, 1923 ................................. 27

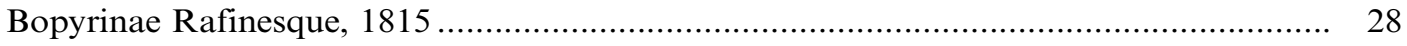

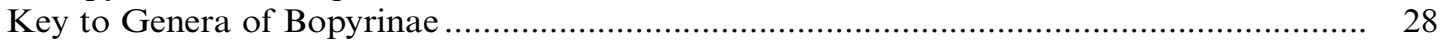

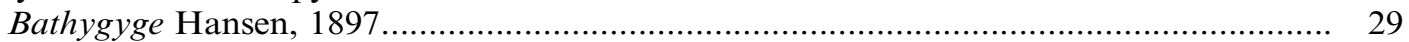

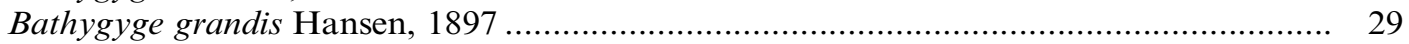

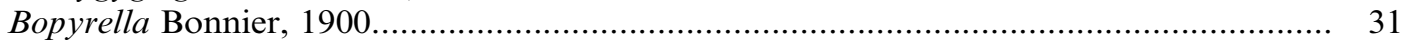

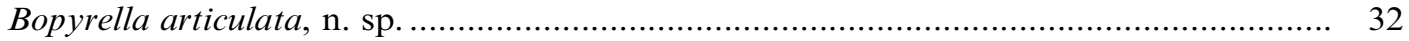

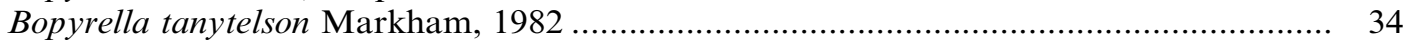

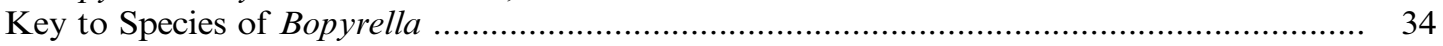

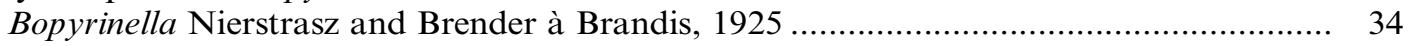

Bopyrinella albida Shiino, 1958............................................................................ 35

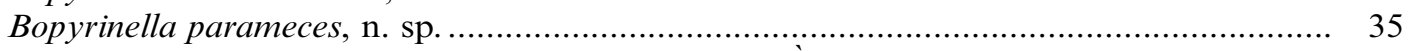

Key to Species of Bopyrinella Nierstrasz and Brender À Brandis, 1925 .......................... 37

Bopyrione Bourdon and Markham, 1980 ...................................................... 37

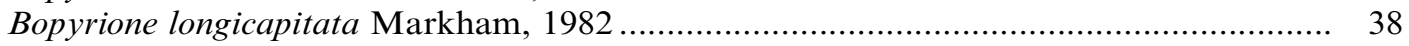

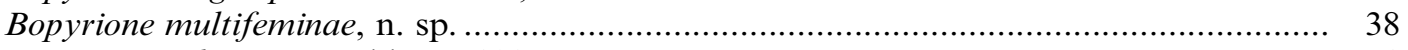

Bopyrione toloensis Markham, 1982 ................................................................... 41

Key to Species of Bopyrione Bourdon and Markham, 1980 ...................................... 41

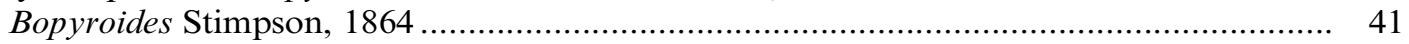

Bopyroides hippolytes (Kröyer, 1838) ............................................................ 41

Bopyroides shiinoi Rybakov and Andeev, 1991 .................................................... 43

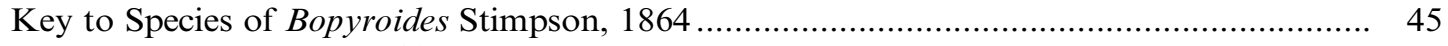

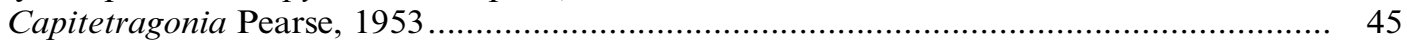

Capitetragonia elliptica (Markham, 1992), n. comb. ................................................... 46

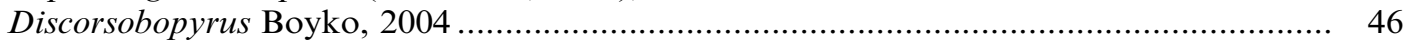

Discorsobopyrus stebbingi (Nierstrasz and Brender à Brandis, 1923) .......................... 46

Litobopyrus Markham, 1982 ........................................................................ 47

Litobopyrus longicaudatus Markham, 1982 ........................................................ 47 
Parabopyrella Markham, 1982

Parabopyrella choprai (Nierstrasz and Brender à Brandis, 1929)

Parabopyrella cuspidata, n. sp.

Parabopyrella distincta (Nierstrasz and Brender à Brandis, 1923).

Parabopyrella elongata (Shiino, 1949)

Parabopyrella hodgarti (Chopra, 1923).

Parabopyrella indica (Chopra, 1923)

Parabopyrella perplexa Markham, 1990 .............................................................. 57

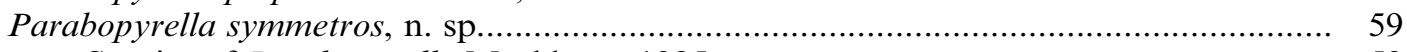

Key to Species of Parabopyrella Markham, 1985 ..................................................... 59

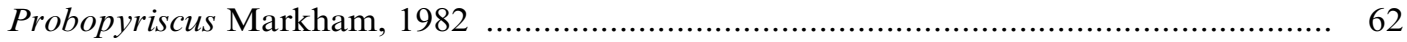

Probopyriscus novempalensis Markham, 1982 ................................................ 62

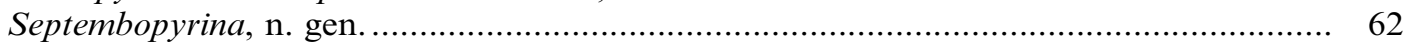

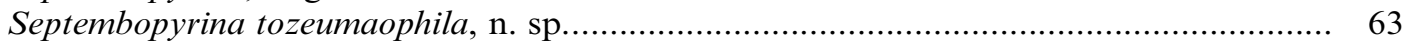

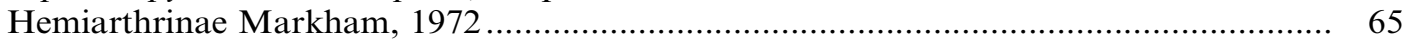

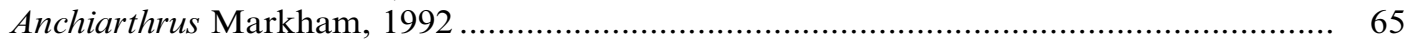

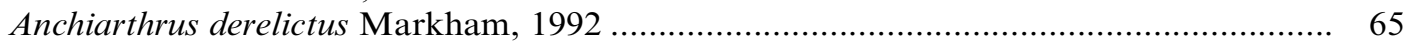

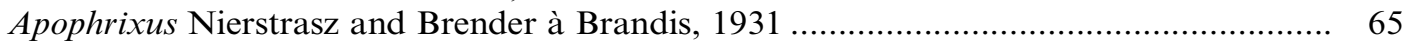

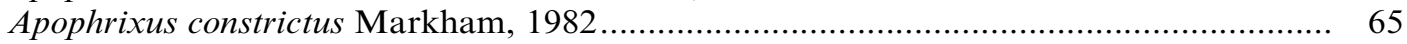

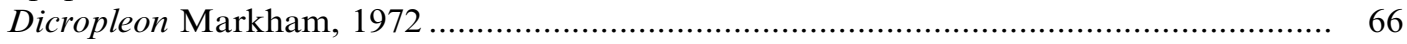

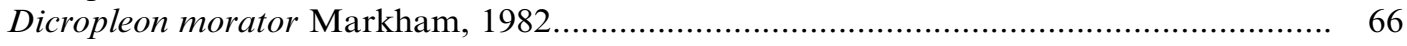

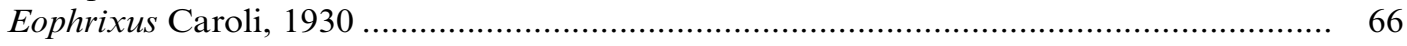

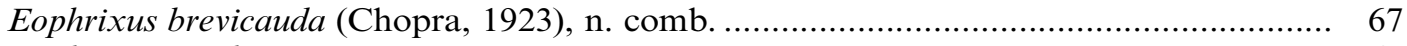

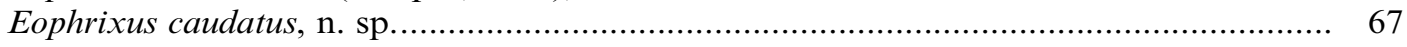

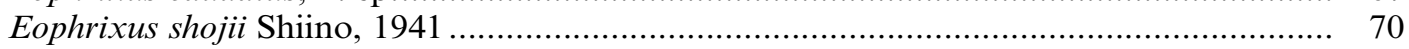

Key to Species of Eophrixus Caroli, 1930 ............................................................... $\quad 70$

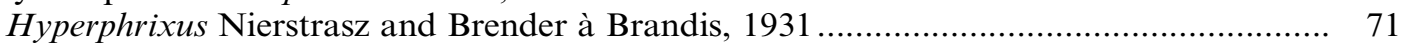

Hyperphrixus filiformis (Chopra, 1923), n. comb. ............................................. 71

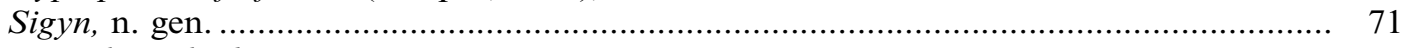

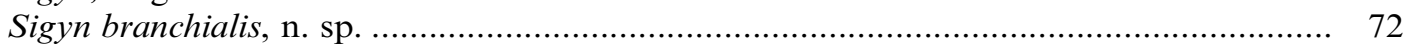

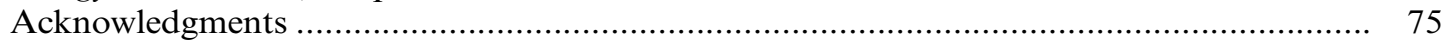

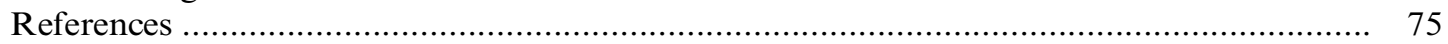




\begin{abstract}
A review of 37 bopyrid isopods known to infest 43 species of caridean shrimps in China is presented, based on literature records and new material. Synonymies are provided for all species, with descriptions and detailed illustrations given for species represented by material examined herein. Bopyrids recorded as new species or new Chinese records belong to the subfamilies Argeiinae ( 2 or 3 species, depending on the identity of Argeia sp.: Argeia pugettensis Dana, 1852, Argeia sp., Stegoalpheon kempi Chopra, 1923), Pseudioninae (2 species: Paranikione sibogae, n. gen. n. sp., and Paranikione distorta, n. sp.), Bopyrinae (13 species: Bathygyge grandis Hansen, 1897, Bopyrella articulata, n. sp., Bopyrinella parameces, n. sp., Bopyrione multifeminae, n. sp., Bopyroides hippolytes (Kröyer, 1838), Bopyroides shiinoi Rybakov and Andeev, 1991, Parabopyrella cuspidata, n. sp., Parabopyrella distincta (Nierstrasz and Brender à Brandis, 1923), Parabopyrella elongata (Shiino, 1949), Parabopyrella hodgarti (Chopra, 1923), Parabopyrella perplexa Markham, 1990, Parabopyrella symmetros, n. sp., and Septembopyrina tozeumaophila, n. gen., n. sp.), and Hemiarthrinae (2 species: Eophrixus caudatus, n. sp., and Sigyn branchialis, n. gen, n. sp.), collected from the South China Sea (7 species), East China Sea (3 species), Yellow Sea (4 species), and East and South China seas (2 species). Three new genera and 10 new species are described, with an additional four species newly recorded from Chinese waters. The genus Argeia is reviewed and a new genus is erected for Argeia lowisi Chopra, 1923, and Argeia nierstraszi Shiino, 1958. Capitetragonia Pearse, 1953, is recognized as the senior synonym of Probopyria Markham, 1985. The genus Parabopyriscus and species Parabopyriscus stellatus are deemed to be available from Markham, 1982, not Markham 1985. Hemiarthrus filiformis Chopra, 1923, is transferred to Hyperphrixus Nierstrasz and Brender à Brandis, 1931. The species composition of Eophrixus Caroli, 1930, is reviewed, the type species designation is clarified, and two species of Hypophryxus Shiino, 1934, are transferred into this genus. A key to all genera of Argeiinae and Bopyrinae and keys to species of seven bopyrine genera are provided, as is a list (with hosts) of the 82 bopyrid and ionid species currently known to infest Chinese noncaridean decapods.
\end{abstract}

\section{INTRODUCTION}

Bopyridae Rafinesque, 1815, is the largest and best-defined epicaridean family, species of which infest their decapod hosts primarily branchially or abdominally. Markham (1985a) and Martin and Davis (2001) considered Bopyridae as divided into 10 subfamilies. Subsequently, Bopyrophryxinae Condreanu, 1965, was synonymized with Pseudioninae Codreanu, 1967 (Bourdon and Boyko, 2005). Boyko et al. (2013) used 18S rDNA to explore the phylogeny of epicarideans and their results showed that Ioninae H. Milne Edwards, 1840, should be restricted to the type genus and removed from Bopyridae; the remaining species formerly in Ioninae were placed into a newly described Keponinae Boyko et al., 2013. Additionally Boyko et al. (2013) showed that Entophilinae Richardson, 1903, did not belong to Bopyridae but rather was a family within Cryptoniscoidea. Therefore, Bopyridae currently includes eight subfamilies, four of which (Argeiinae Markham, 1977, Bopyrinae Rafinesque, 1815, Hemiarthrinae Markham, 1972, and Pseudioninae
Codreanu, 1967) are found parasitizing caridean shrimp, with all but the latter subfamily found exclusively on carideans.

Studies on bopyrids from China, except for Hong Kong and Taiwan, were conducted primarily from 2006 onward. Prior to 2006, Nierstrasz and Brender à Brandis (1929, 1930, 1931) reported six bopyrids from Chinese waters, while Markham (1982, 1990, 1992a) and Boyko (2004) recorded 54 species. An et al. (e.g., 2006a, b, 2007a, 2007b, 2008, 2009a, 2009b, 2010, 2011, 2012a, 2012b, 2012c, 2012d, 2013a, 2013b, 2013c, 2013d, 2013e, 2014a, 2014b), Duan et al., (2008), and Williams and An (2009) reported 84 species in seven subfamilies and 46 genera. Currently, there are 119 bopyrid species known from Chinese waters (caridean parasites listed in the text plus the noncaridean parasites in table 1).

The materials reported on herein were included in an unpublished dissertation by one of us (An, 2006, not a published work according to the criteria of the ICZN). We reexamined all the specimens and have 


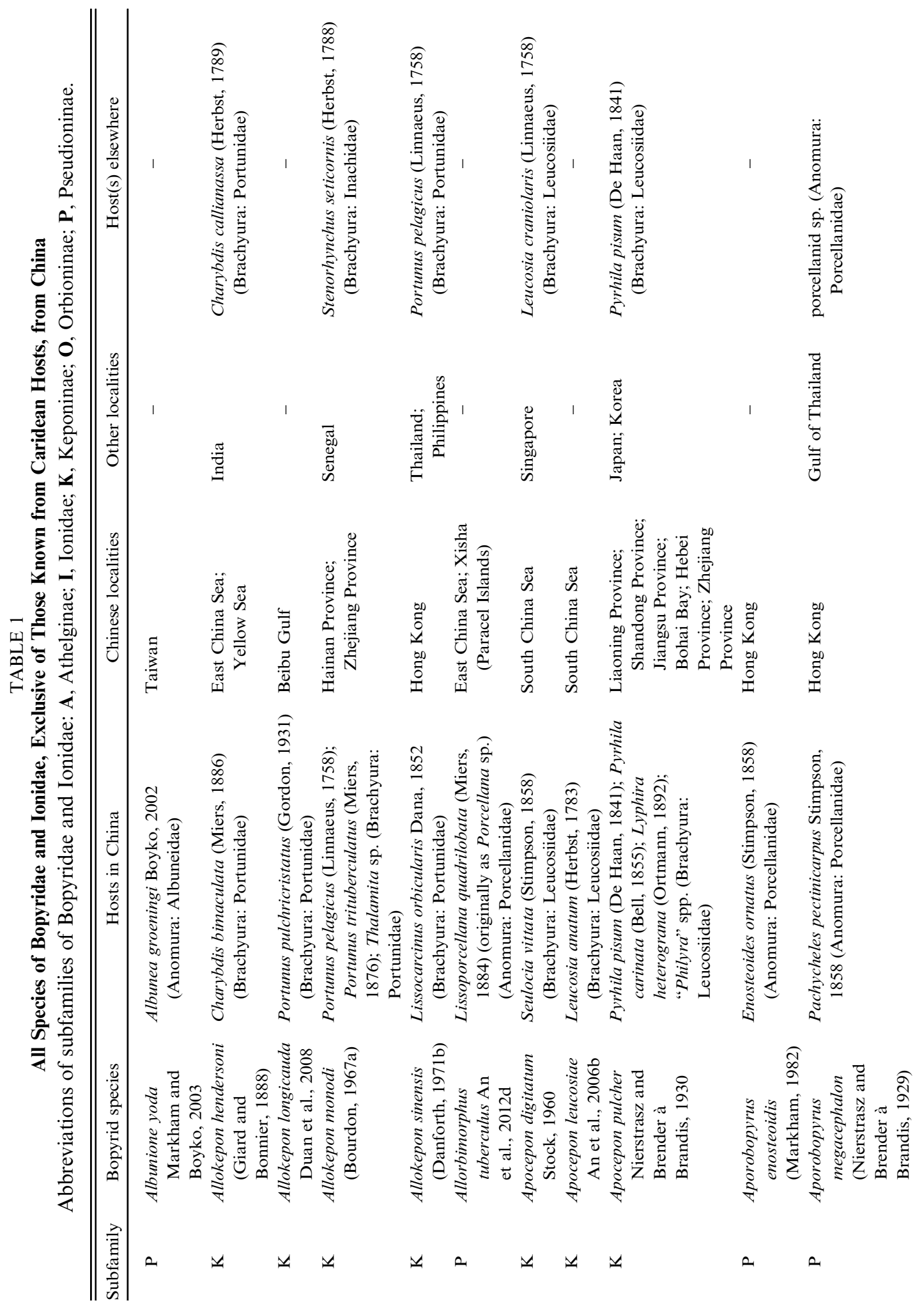




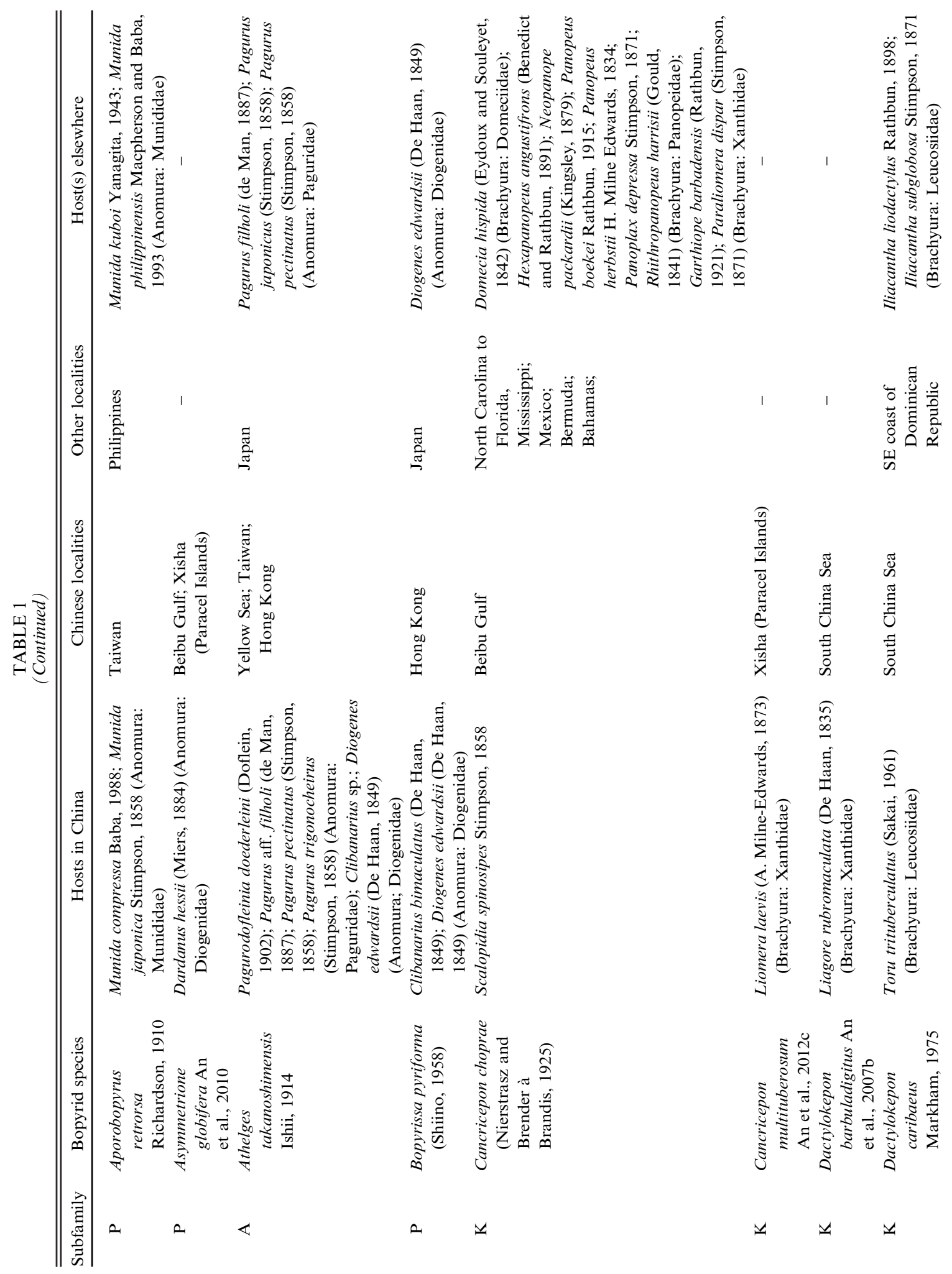




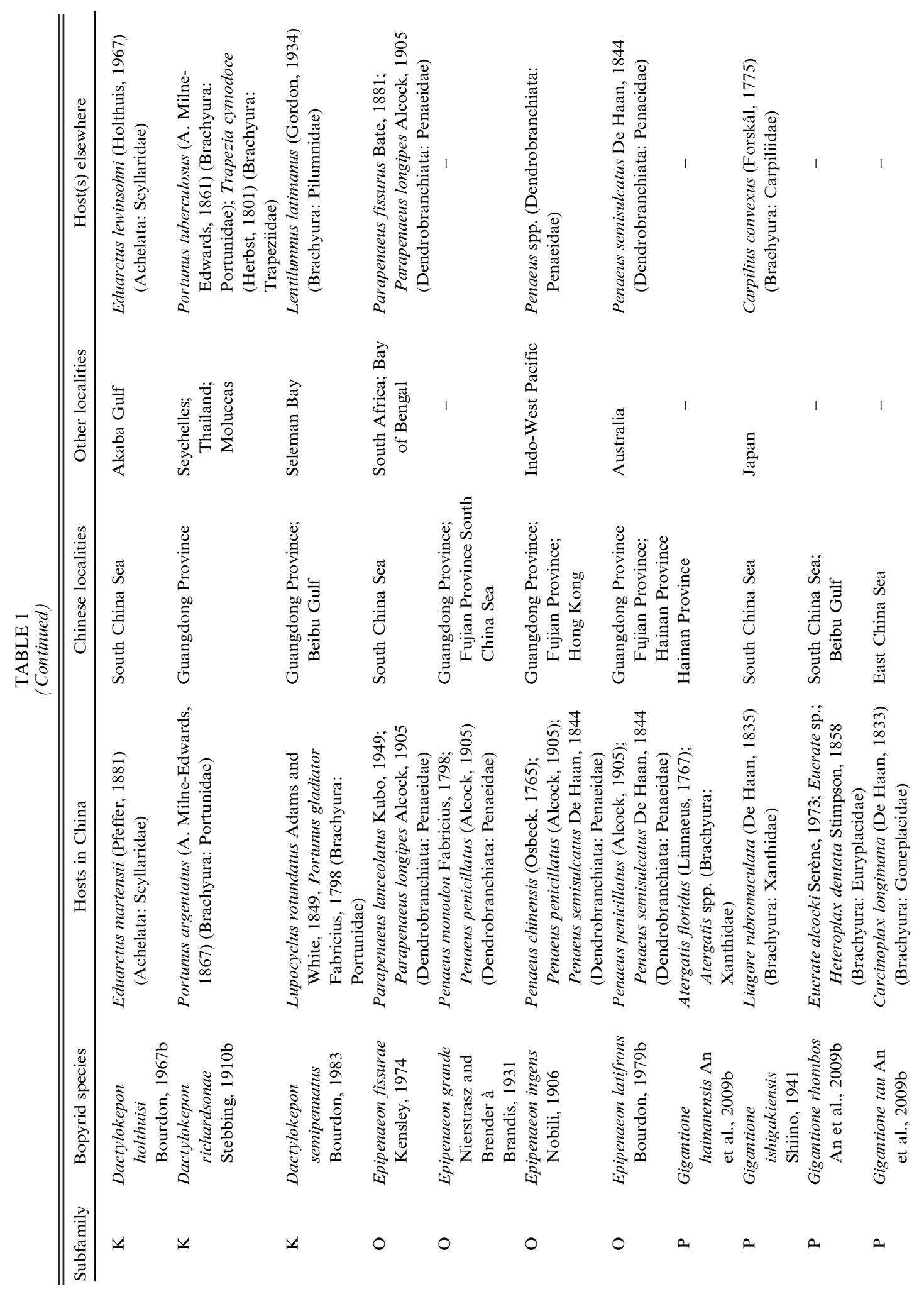




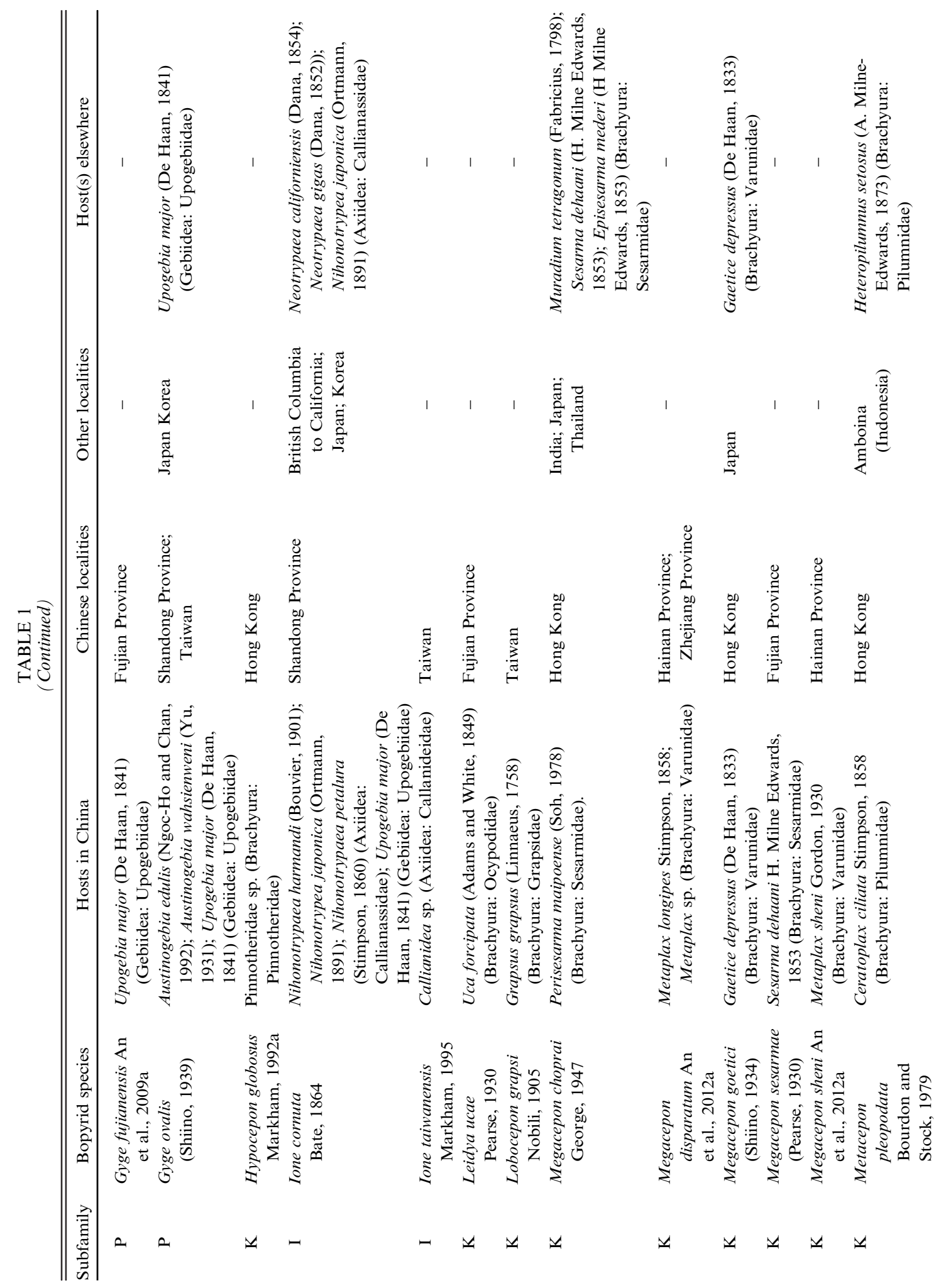




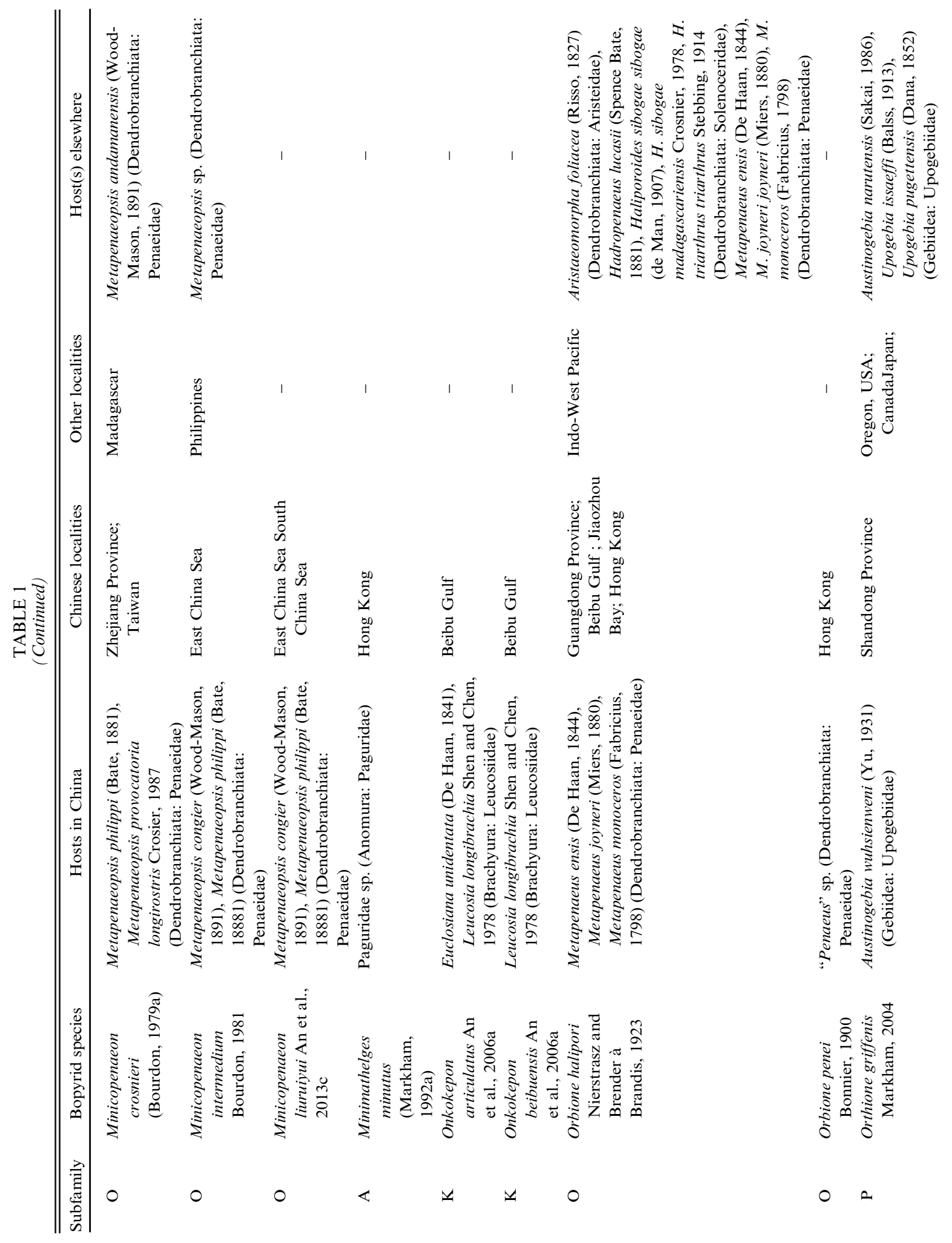




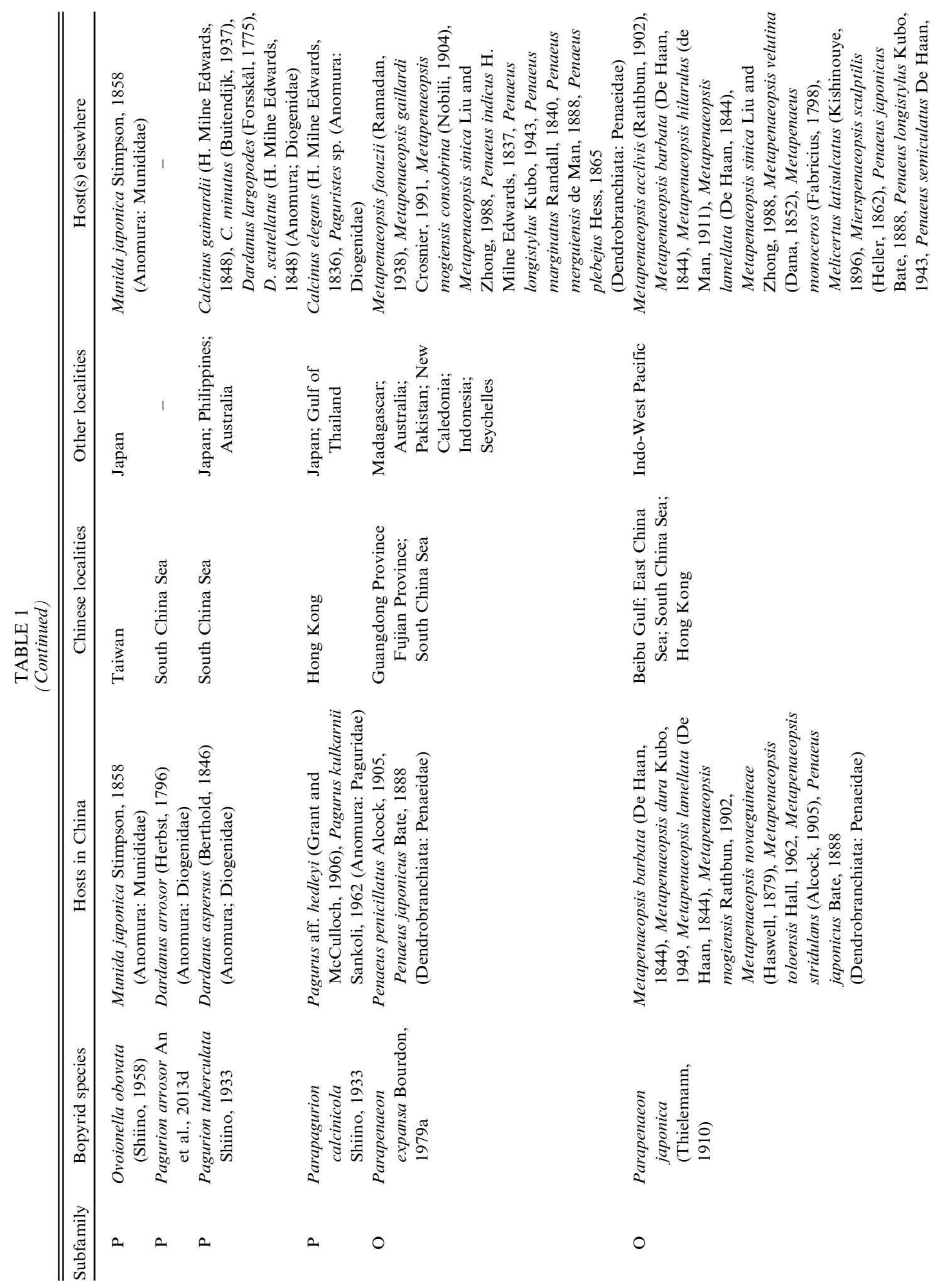




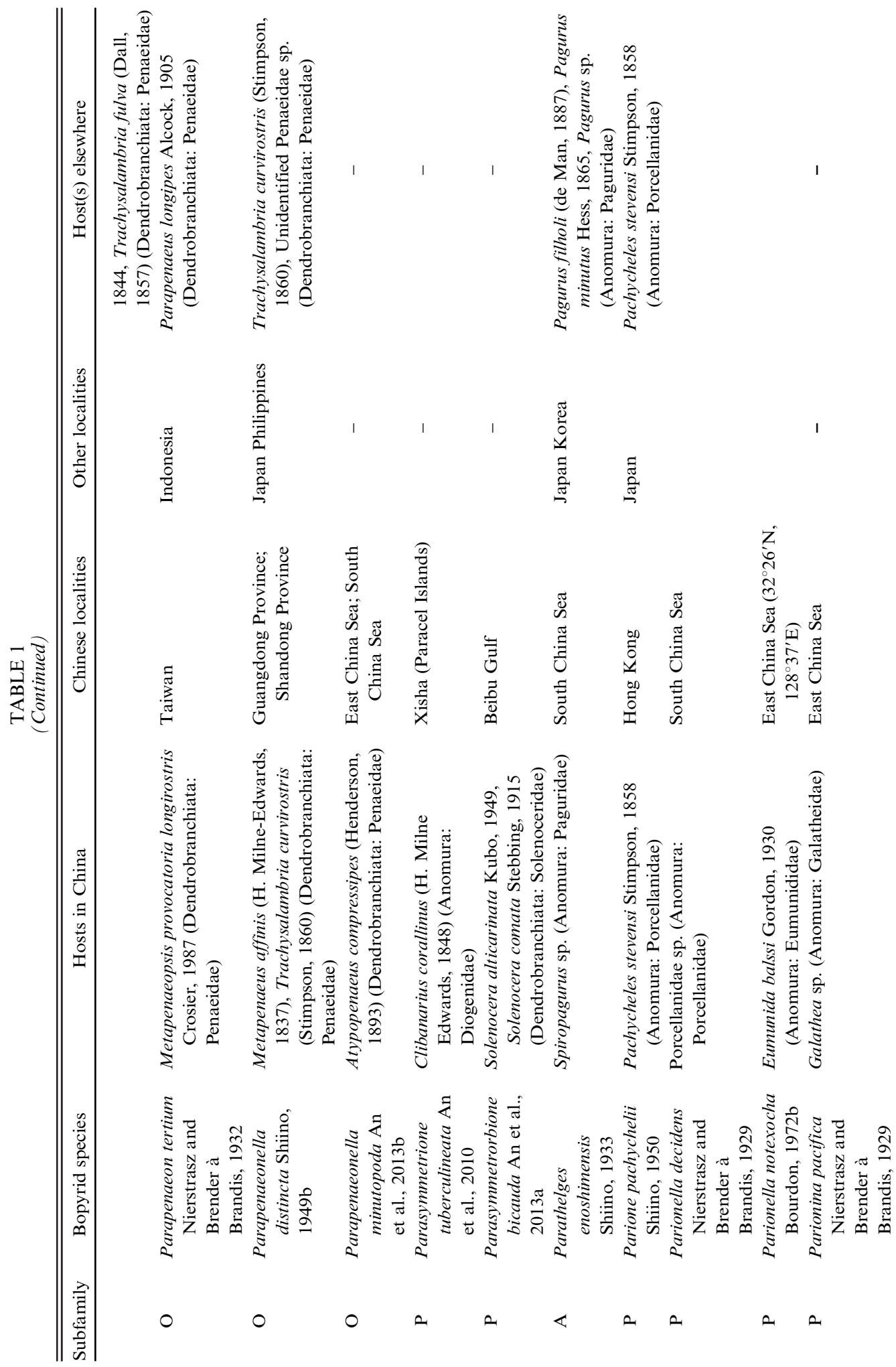




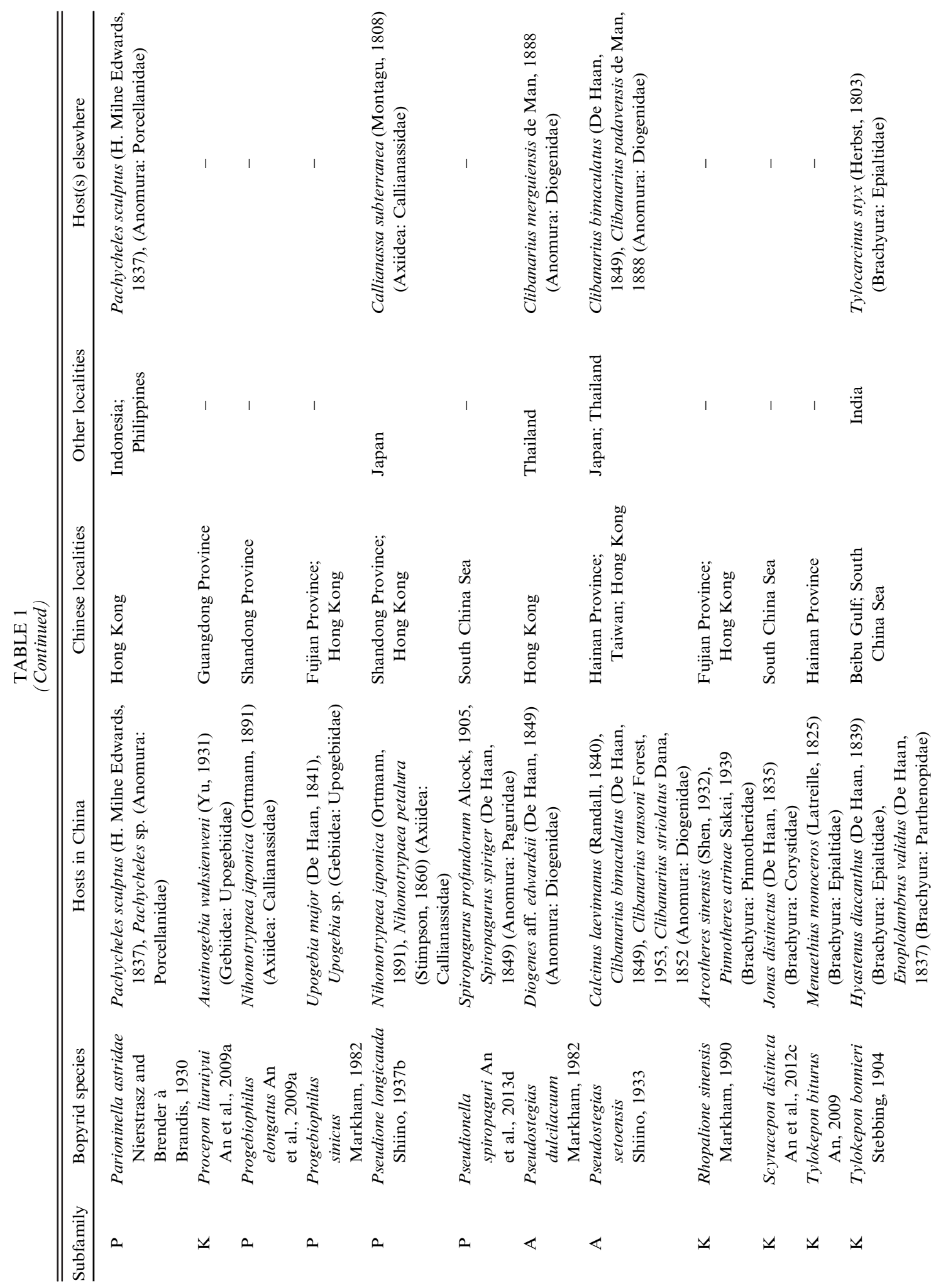




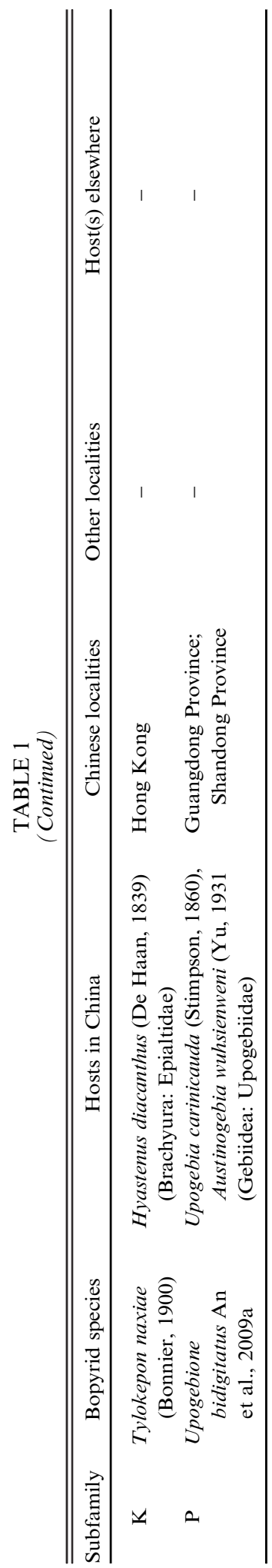

concluded that they represent 20 species in 12 genera belonging to four subfamilies. The names for all species as given in An (2006) are included in the synonymy lists, but with the notation that several names used as new in that dissertation are treated here in synonymy and are not available names. All these species are described (or redescribed) with figures of males and females presented. A key to all genera of Argeiinae and Bopyrinae and keys to species of seven bopyrine genera are provided, as is a list (with hosts) of the 82 bopyrid and ionid species currently known to infest Chinese noncaridean decapods.

In addition to the new Chinese species and records, several taxonomic decisions are made in this paper. The genus Argeia is reviewed and a new genus is erected for Argeia lowisi Chopra, 1923, and Argeia nierstraszi Shiino, 1958. Capitetragonia Pearse, 1953 , is recognized as the senior synonym of Probopyria Markham, 1985. The genus Parabopyriscus Markham and species Parabopyriscus stellatus Markham are deemed to be available from Markham, 1982, not Markham 1985. Hemiarthrus filiformis Chopra, 1923, is transferred to Hyperphrixus Nierstrasz and Brender à Brandis, 1931. The species composition of Eophrixus Caroli, 1930, is reviewed, the type species designation is clarified, and two species of Hypophryxus Shiino, 1934, are transferred into this genus.

\section{SUMMARY LIST OF NEW TAXA, TAXONOMIC DECISIONS, AND CHINESE RECORDS}

\section{Argeiinae}

Stegoargeia, n. gen.

Stegoargeia lowisi (Chopra, 1923), n. comb.

Stegoargeia nierstraszi (Shiino, 1958), n. comb.

\section{Pseudioninae}

Paranikione sibogae, n. gen., n. sp.

Paranikione distorta, n. sp.

\section{Bopyrinae}

Bopyrella articulata, n. sp.

Bopyrinella parameces, n. sp.

Bopyrione multifeminae, n. sp.

Bopyroides shiinoi Rybakov and Andeev, 1991 (new Chinese record)

Capitetragonia Pearse, 1953 (= Probopyria Markham, 1985), new synonymy 
Capitetragonia alphei (Richardson, 1900), n. comb.

Capitetragonia elliptica (Markham, 1992), n. comb.

Parabopyrella cuspidata, n. sp.

Parabopyrella distincta (Nierstrasz and Brender à Brandis, 1923) (new Chinese record)

Parabopyrella elongata (Shiino, 1949) (new

Chinese record)

Parabopyrella hodgarti (Chopra, 1923) (new

Chinese record)

Parabopyrella symmetros, n. sp.

Septembopyrina tozeumaophila, n. gen., n. sp.

\section{Hemiarthrinae}

Eophrixus brevicaudata (Chopra, 1923), n. comb.

Eophrixus caudatus, n. sp.

Eophrixus leptochelae (Pillai, 1966), n. comb.

Eophrixus pikei (Bruce, 1968), n. comb.

Sigyn branchialis, n. gen., n. sp.

\section{MATERIALS AND METHODS}

Materials for this study originated from the China Comprehensive Oceanographic Survey of the 1950s and 1989-1991. All materials examined are deposited in the Institute of Oceanology, Chinese Academy of Sciences, Qingdao, China (IOCAS), except those specimens studied at the Smithsonian Institution, Washington, D.C. (USNM). IOCAS collection abbreviations are: CIECR, CIEAL, CIEPR, CIEGL, CIEOG, CIEHI, where $\mathrm{C}=$ Crustacea, $\mathrm{I}=$ Isopoda, $\mathrm{E}=$ Epicaridea and the last two letters = host family as follows: $\mathrm{AL}=$ Alpheidae, $\mathrm{CR}=$ Crangonidae, $\mathrm{GL}=$ Glyphocrangonidae, $\mathrm{HI}=$ Hippolytidae, $\mathrm{OG}=$ Ogyrididae, $\mathrm{PR}=$ Processidae. Animals were viewed and drawn using a Zeiss Stemi SV Apo. Males for scanning electron microscope study were fixed in $2.5 \%$ glutaraldehyde in 0.2 M Millonig's phosphate buffer at $\mathrm{pH} 7.4$ for $1.5 \mathrm{hr}$ and postfixed in $1 \%$ osmium tetroxide in $0.2 \mathrm{M}$ Millonig's buffer for $1 \mathrm{hr}$. The specimens were then dehydrated through a graded series of ethanol, followed by critical point drying. After sputter coating with colloidal gold, the specimens were examined with a KYKY2800B scanning electron microscope. Synonymies do not include all records of species from sources such as textbooks, government documents, and most publications where species are mentioned without locality or host data. Bibliographic references are provided for all bopyrid taxa, including those listed in the tables.

\section{SYSTEMATIC ACCOUNT}

$$
\begin{gathered}
\text { Crustacea Brünnich, } 1772 \\
\text { Isopoda Latreille, } 1817 \\
\text { Cymothoida Wägele, } 1989 \\
\text { Bopyridae Rafinesque, } 1815 \\
\text { Argeiinae Markham, } 1977
\end{gathered}
$$

Diagnosis (modified from Markham, 1977): Female: Body rounded, ranging from subtriangular to nearly circular; weakly distorted, up to $20^{\circ}$; all body regions and usually all segments distinct; head much broader than long, oval to fusiform, barbula with two or three tapered lobes on each side, otherwise smooth; maxilliped with articulated palp or tuft of setae in palp area; pereopods small; brood pouch usually wide open; pleon of six pleomeres, first five bearing prominent lateral plates, pleomere 6 with uniramous uropods subequal in size and shape to lateral plates; pleopods uni- or biramous, usually five pairs (occasionally with only first three or four pairs), decreasing in size posteriorly, tuberculiform or as small oval flaps.

Male: All body regions and pereomeres distinct; head small, broader than long, markedly narrower than pereon; pleon fused, anteriorly as broad as final pereomere, semicircular to subtriangular, no indications of segmentation; no pleonal appendages.

REMARKs: Some of Markham's (1977) characters used to justify the erection of Argeiinae, such as the presence of lateral plates and uniramous pleopods on females, are not found in all the genera currently placed in this subfamily (see above diagnosis). As a consequence, the monophyly of this subfamily has been questioned by earlier authors (e.g., Adkison et al., 1982; Bourdon and Bruce, 1983). Adkison et al. (1982) considered Parargeia Hansen, 1897, to be closer to Pseudioninae and the other genera nearer to Bopyrinae, but the molecular phylogeny of Boyko et al. (2013) showed Argeia being the sister taxon to Hemiarthrinae. A molecular analysis of species in all the argeiine genera is needed to 
address questions of Argeiinae monophyly and validity.

\section{KEY TO GENERA OF ARGEIINAE, BASED ON MATURE FEMALES}

1a. Pleon gradually tapering from pereon ... 2

1b. Pleon with pleomere 1 markedly narrower than pereomere 7 . . Eragia Markam, 1977

2a. Pleomeres fused ............... ....... Gareia Bourdon and Bruce, 1983

2b. Pleomeres distinct ... . . . . . . . . . 3

3a. Coxal plates present on at least pereomeres 1 to 4 , or those pereomeres divided laterally; pereopods reduced; body ovoid, ovate or subtriangular . .......... 4

3b. Coxal plates absent, no pereomeres prominently divided laterally; pereopods prominent; body nearly circular . . . . . . . . . . . . . . . . A Argeiopsis Kensley, 1974

4a. Body broader than long . . . . . . . . 5

4b. Body longer than broad ......... 6

5a. Dorsally directed ovate lateral plates present ........ Stegoalpheon Chopra, 1923

5b. Dorsally directed lateral plates lacking ........ Stegoargeia, n. gen. (see below)

6a. Brood pouch almost completely enclosed; lateral plates extending farther to sides than width of pereon ... Parargeia Hansen, 1897

6b. Brood pouch open; lateral plates not extending farther to sides than width of pereon .............. 7

7a. Length of lateral plates and uropods not exceeding width of first pleomere . . . . . .

Argeia Dana, 1852

7b. Length of final lateral plates and uropods exceeding width of first pleomere .. Bopyrosa Nierstrasz and Brender à Brandis, 1923

\section{Argeia Dana, 1852}

Diagnosis (modified from Markham, 1977): Female: Body ovoid, about $3 / 4$ as wide as long, slightly distorted, all body regions and segments distinct; head subrectangular, wider than long; maxilliped palp setose (sometimes articulated); barbula with two or three short projections on each side; pereomeres either bearing coxal plates or prominently divided laterally; oostegites surrounding but not covering marsupium, oostegite 1 with large rounded posterolateral lobe, not tapered; pleon of six pleomeres, first five produced into prominent oval to lanceolate lateral plates; pleopods uniramous, exopodites often reduced to knobs on ventral surface, especially posteriorly; uropods uniramous, of same size and shape as lateral plates.

Male: Body approximately three times as long as wide; head usually much narrower than pereon; pereomeres distinctly separated, subequal in width; pleon triangular, ending in rounded point.

TyPE SPECIES: Argeia pugettensis Dana, 1852 , by monotypy.

Other SPECIES: Argeia atlantica Markham, 1977.

Remarks: Argeia lowisi Chopra, 1923, and A. nierstraszi Shiino, 1958, do not belong in Argeia. Females of both A. pugettensis and $A$. atlantica have an oostegite 1 with a rounded (not tapered) posterior lobe, the first 5 pleomeres with lateral plates and a pair of uniramous pleopods on pleomeres 1-5. However, females of $A$. lowisi and $A$. nierstraszi both have an elongate and tapered oostegite 1 posterior lobe (similar to that seen in Stegoalpheon kempi Chopra, 1923), no lateral plates or biramous pleopods. Although the oostegite 1 is very similar in A. lowisi, A. nier$s t r a s z i$, and $S$. kempi, the presence of five or six pairs of uniramous lateral plates and five pairs of biramous pleopods in $S$. kempi precludes the inclusion of $A$. lowisi and A. nierstraszi in that genus. Therefore, we erect Stegoargeia, n. gen. (type species Argeia lowisi Chopra, 1923), for the type species as well as $A$. nierstraszi. The hosts for both Argeia species are crangonids, while those of Stegoalpheon and Stegoargeia, n. gen., are alpheids. The males of all three genera are very similar and suggest a close relationship between the genera.

\section{Argeia pugettensis Dana, 1852 Figure 1}

Argeia pugettensis Dana, 1852: 804-805 [Puget Sound, Washington, infesting Metacrangon munita (Dana, 1852)]; Dana, 1855: pl. 53, fig. 7a-d; Stimpson, 1857: 511 [Puget Sound, Washington, infesting M. munita]; Stebbing, 1893: 336, 337; Calman, 1898: 281; Richardson, 1899a: 868; Richardson, 1899b: 336-337; Bonnier, 1900: 48, 61, 171, 221, 327-328, fig. 55; Richardson, 1900: 308; Gerstaecker, 1901: 185; Richardson, 1904a: 45, 60-64, figs. 35-40 [Bering 
Sea to San Diego Bay, California, infesting Argis alaskensis (Kingsley, 1883), Argis crassa (Rathbun, 1899), Argis dentata (Rathbun, 1902), Argis lar (Owen, 1839), Argis ovifer (Rathbun, 1902), Crangon alaskensis Lockington, 1877, Crangon alba Holmes, 1900, Crangon dalli Rathbun, 1902, Crangon franciscorum angustimanus Rathbun, 1902, Crangon nigromaculata Lockington, 1877, Crangon propinquus Stimpson, 1860, M. munita, Neocrangon communis Rathbun, 1899]; Richardson, 1904b: 858; Richardson, 1905a: 220 [British Columbia and Alaska, infesting Argis dentata (Rathbun, 1902), C. alaskensis, N. communis]; Richardson, 1905b: 544-550, figs 586-597 [same material as Richardson, 1904a]; Richardson, 1909: 122 [Japan and Korea, infesting Argis sp.]; Chopra, 1923: 476-478, 480; Nierstrasz and Brender à Brandis, 1923: 87; Fee, 1927: 16, 40 [British Columbia, infesting Lissocrangon stylirostris (Holmes, 1900), M. munita]; Nierstrasz and Brender à Brandis, 1929: 16 [California, infesting Crangon sp.]; Fraser, 1932: 64; Hiraiwa, 1933: 53; Shiino, 1933: 249, 277-279, fig. 11 [Japan, infesting unknown host]; Gurjanova, 1936a: 219221, fig. 138 [Kamchatka Peninsula and Bering Sea, infesting Argis spp., Crangon spp.]; Gurjanova, 1936b: 258; Shiino, 1937a: 299 [Japan, infesting Crangon affinis De Haan, 1849]; Ricketts and Calvin, 1939: 185, 281; Baer, 1946: 65; Hatch, 1947: 164, 224, pl. 9, figs. 110-112; Ricketts and Calvin, 1948: 185, 320; Baer, 1951: 69-70; Ricketts and Calvin, 1952: 239, 438; Shiino, 1952: 34; Menzies and Miller, 1954: 141, 153, fig. 65c, d; Shiino, 1958: 56, pl. 3, fig. 8 [Japan, infesting A. lar, C. affinis, Neocrangon sagamiensis (Balss, 1913)]; Oguro, 1961: 43-47, figs. 1-3, 5-7 [Japan, infesting C. affinis]; Danforth, 1963: 35, 52, 54, 60, 61, 63, 64, 68, pl. 2, fig. 1, pl. 4, figs. 4-6; Sindermann and Rosenfield, 1967: 351; Bourdon, 1968: 358; George and Strömberg, 1968: 253 [Washington, infesting $A$. dentata, $C$. alaskensis, Crangon franciscorum Stimpson, 1856, Eualus suckleyi (Stimpson, 1854), Mesocrangon munitella (Walker, 1898), M. munita, N. communis]; Ricketts and Calvin, 1968: 286, 488; Schultz, 1969: 323-324, figs. 516-517;
Danforth, 1970: 41; 42, 56-57, 143, 150, fig. 5a-c; Sindermann, 1970: 171; Strömberg, 1971: 28; Kozloff, 1974: 148; Miller, 1975: 285, 287, 305, pl. 64, fig. 18; Markham, 1977: 112-114 [Washington and California, infesting $C$. alaskensis, $C$. franciscorum, Neocrangon resima (Rathbun, 1902)]; Rudy and Rudy, 1979: 122, 124, 126; Beck, 1980: 135; Bourdon et al., 1981: 502; Jay, 1985: i-vii, 1-63 [California, infesting C. franciscorum]; Ricketts et al., 1985: 328, 533; Markham, 1986: 156, 161; Bourdon, 1987: 342-343, fig. 17.23; Strathmann, 1987: 436; Kim and Kwon, 1988: 199, 201, 207-210, fig. 6 [Korea, infesting A. lar, C. affinis, possibly Crangon hakodatei Rathbun, 1902]; Jay, 1989: 68-76 [California, infesting C. franciscorum]; Sinder mann, 1990: 196; Brusca and Wilson, 1991: 148, fig. 2a; Feeney, 1995: 6; Trilles, 1999: 285, 292, 334, fig. 8.13C; Brusca et al., 2001: 20; Shields, 2001: 313; An, 2006: 6163, fig. 26 [China, infesting C. affinis, Crangon cassiope de Man, 1906, Crangon crangon (Linnaeus, 1758)]; Espinosa-Pérez and Hendrickx, 2006: 237; Chaplin-Ebanks and Curran, 2007: 73; Marin Jarrin, 2007: x, 54, 90-92 96, 100, 118 [Oregon, infesting Lissocrangon stylirostris (Holmes, 1900)]; An et al., 2008: 225-226 [China, infesting C. affinis, C. cassiope, C. crangon]; Liu: 2008: Marin Jarrin and Shanks, 2008: 691; 613-620 [Oregon, infesting L. stylirostris]; Romero-Rodríguez and Román-Contreras, 2008: 1207; Wicksten, 2008: 143; EspinosaPérez et al., 2009: 229; Williams and An, 2009: 122; Dumbauld et al., 2011: 337; Han and Li, 2010: 228; An, 2011: 130-133, figs. 5-1-5-3 [China, infesting $C$. affinis, $C$. cassiope, C. crangon]; Marin Jarrin and Shanks, 2011: 237; Wicksten, 2012: 106; Williams and Boyko, 2012: 7; Penha-Lopes et al., 2013: 35; Rudy and Rudy, 2013: 208, 210, 272; Sherman and Curran, 2013: 1336; Romero-Rodríguez and Román-Contreras, 2014: 470; Seo et al., 2014: 413-417, fig. 2 [Korea, infesting A. lar]; Cericola and Williams, 2015: 239.

Argeia pauperata Stimpson, 1857: 511 [San Francisco, California, infesting C. franciscorum]; Stebbing, 1893: 415; Calman, 1898: 281; Bonnier, 1900: 61, 171, 221, 328, 381; Gerstaecker, 1901: 185, 266; 
Richardson, 1905b: 551; Chopra, 1923: 476-478; Nierstrasz and Brender à Brandis, 1923: 87; Gifford, 1934: 1-20, pls. 1-5; [California, infesting C. franciscorum]; Danforth, 1963: 20, 28, 34; 68, 75, pl. 1, fig. 4, pl. 2, fig. 2, pl. 4, figs. 1-3; Schultz, 1969: 323; Danforth, 1970: 41, 56, 150, fig. 4d-f; Strömberg, 1971: 28; Miller, 1975: 287, 305; Nelson et al., 1986: 121-124.

Argeja [sic] pugettensis Cornalia and Panceri, 1861: 86, 16.

?Bopyrus sp. Bate, 1888: 485 [Japan, infesting C. affinis].

Argeia sp. Calman, 1898: 261, 281 [Washington, USA, infesting C. affinis].

Argeia depauperata [sic] Richardson, 1899a: 868; Richardson, 1899b: 336, 337; Richardson, 1900: 308.

Argeia (?) [spp.] Bonnier, 1900: 221.

Argeia Calmani Bonnier, 1900: 171, 221, 329, 381 [Washington, infesting $C$. affinis] (nomen nudum).

Argeia Pingi Yü, 1935: 52-53 [Hopei and Shantung Provinces, China, infesting $C$. cassiope].

Argaeia [sic] pugettensis-MacGinitie and MacGinitie, 1949: 266 [west coast of United States, infesting C. alaskensis]; MacGinitie and MacGinitie, 1968: 265-266.

Material Examined: Infesting Crangon affinis De Haan, 1849. 2우, ot (CIECR 007601), South Yellow Sea, Stn.76, $123^{\circ} 30^{\prime} \mathrm{E}$, $27^{\circ} 20^{\prime} \mathrm{N}, 45 \mathrm{~m}, 18$ April 1975; 2우, 2 ○’ $^{\star}$ (CIECR020801), South Yellow Sea, Stn. 208, $127^{\circ} 00^{\prime} \mathrm{E}, 30^{\circ} 30^{\prime} \mathrm{N}, 46 \mathrm{~m}, 12$ July 1968 ; 웅 o (CIECR104941), Yellow Sea, Stn.10494, $122^{\circ} 00^{\prime} \mathrm{E}, 35^{\circ} 00^{\prime} \mathrm{N}, 52 \mathrm{~m}, 13 \mathrm{June} 2004$; 2우, $20^{\star} 0^{\star}$ (CIECR007602), South Yellow Sea, Stn.76, $123^{\circ} 30^{\prime} \mathrm{E}, 27^{\circ} 20^{\prime} \mathrm{N}, 45 \mathrm{~m}, 10$ June 1975; \&, ơ (CIECR030601), Yellow Sea, Stn. $306,126^{\circ} 00^{\prime} \mathrm{E}, 29^{\circ} 30^{\prime} \mathrm{N}, 60 \mathrm{~m}, 13$ November 1957; 우 (CIECR350801), Yellow Sea, Stn. $3058,120^{\circ} 00^{\prime} \mathrm{E}, 35^{\circ} 00^{\prime} \mathrm{N}, 81 \mathrm{~m}, 12$ September 1992; 앙 ơ (CIECR626301); South China Sea, Stn. $6263,107^{\circ} 30^{\prime} \mathrm{E}, 19^{\circ} 00^{\prime} \mathrm{N}, 77 \mathrm{~m}, 8$ March 1962; 우, ơ (CIECR008101), South Yellow Sea, Stn. 81, $122^{\circ} 00^{\prime} \mathrm{E}, 27^{\circ} 10^{\prime} \mathrm{N}, 31 \mathrm{~m}, 8$ June 1975; 오, ơ (CIECR005101), South Yellow Sea, Stn. 51, $123^{\circ} 20^{\prime} \mathrm{E}, 28^{\circ} 30^{\prime} \mathrm{N}, 65 \mathrm{~m}$, 18 April, 1975; 우 o (CIECR000101), South Yellow Sea, Stn. $1,121^{\circ} 00^{\prime} \mathrm{E}, 26^{\circ} 30^{\prime} \mathrm{N}, 75 \mathrm{~m}$, 29 April 1976; ㅇ, ơ (CIECR590501),
Shazikou, Qingdao, Shandong Province, 16 May 1959, coll. Fenxuan Zhang; 2oㅇ, 200 (CIECR580901), South Yellow Sea, Stn. 81, $122^{\circ} 00^{\prime} \mathrm{E}, \quad 27^{\circ} 10^{\prime} \mathrm{N}, 31 \mathrm{~m}, 20$ September 1958; 2웅, 20ิ ơ (CIECR303801), Yellow Sea, Stn. $3038,123^{\circ} 45^{\prime} \mathrm{E}, 36^{\circ} 00^{\prime} \mathrm{N}, 71.5 \mathrm{~m}, 10$ November 1958.

Infesting Crangon crangon (Linnaeus, 1758). 2웅, 20ㅇ (CIECR530401), Yantai Fish Market, Shandong Province, 20 April 1953; 2oㅇ, 2ơ (CIECR570101), Shazikou, Qingdao, Shandong Province, 20 January 1957, coll. Shaowu Wang, Xiuxi Zhang and Zhengang Fan; ᄋ, ơ (CIECR550401), Yantai, Shandong Province, 5 April 1955, coll. Engze Yang; 옹 o (CIECR500301), Beidai He, Hebei Province, 5 March 1950.

Infesting Crangon cassiope de Man, 1906.

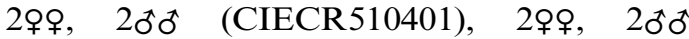
(CIECR510402), Yantai, Shandong Province, 6 April 1951.

DESCRIPTION: (CIECR007601): Length 8.12 $\mathrm{mm}$, pereon length $4.58 \mathrm{~mm}$, maximal width $6.2 \mathrm{~mm}$, head length $0.94 \mathrm{~mm}$, head width $1.87 \mathrm{~mm}$, distorted $36^{\circ}$ (fig. 1A, B). All segments distinct. Head with narrow frontal lamina, anterior edge of head deeply bilobate (fig. 1A), eyes lacking. Antennule of three articles, antenna of five articles, terminally setose. Maxilliped (fig. 1C, D) with setose palp, plectron sharp, anterior article two times larger than posterior article. Barbula with two pairs of smooth falcate lateral projections on each side (fig. 1E).

Pereon broadest across third pereomere (fig. 1A). Coxal plates very reduced, only visible on first three pereomeres of long side. Dorsolateral bosses on first three pereomeres of longer side, and first four pereomeres on shorter side. Tergal projections on longer side extended, tapeing distally to sharp tip. Brood pouch open (fig. 1B). Oostegite 1 (fig. $1 \mathrm{~F}, \mathrm{G}$ ) with nearly smooth internal ridge, posterolateral point lacking. Posterior pereopods larger than anterior pairs, ischium with enlarged tubercular lobe, dactyli blunt (fig. 1H, I). Pleon of six pleomeres, first five pleomeres with lateral plates and uniramous pleopods. Sixth pleomere without lateral plates, with uniramous uropods (fig. 1B).

DesCRIPTION: Male (CIECR007601): Length $2.26 \mathrm{~mm}$, maximal width across pereomere $4,0.71 \mathrm{~mm}$, head width $0.43 \mathrm{~mm}$, 

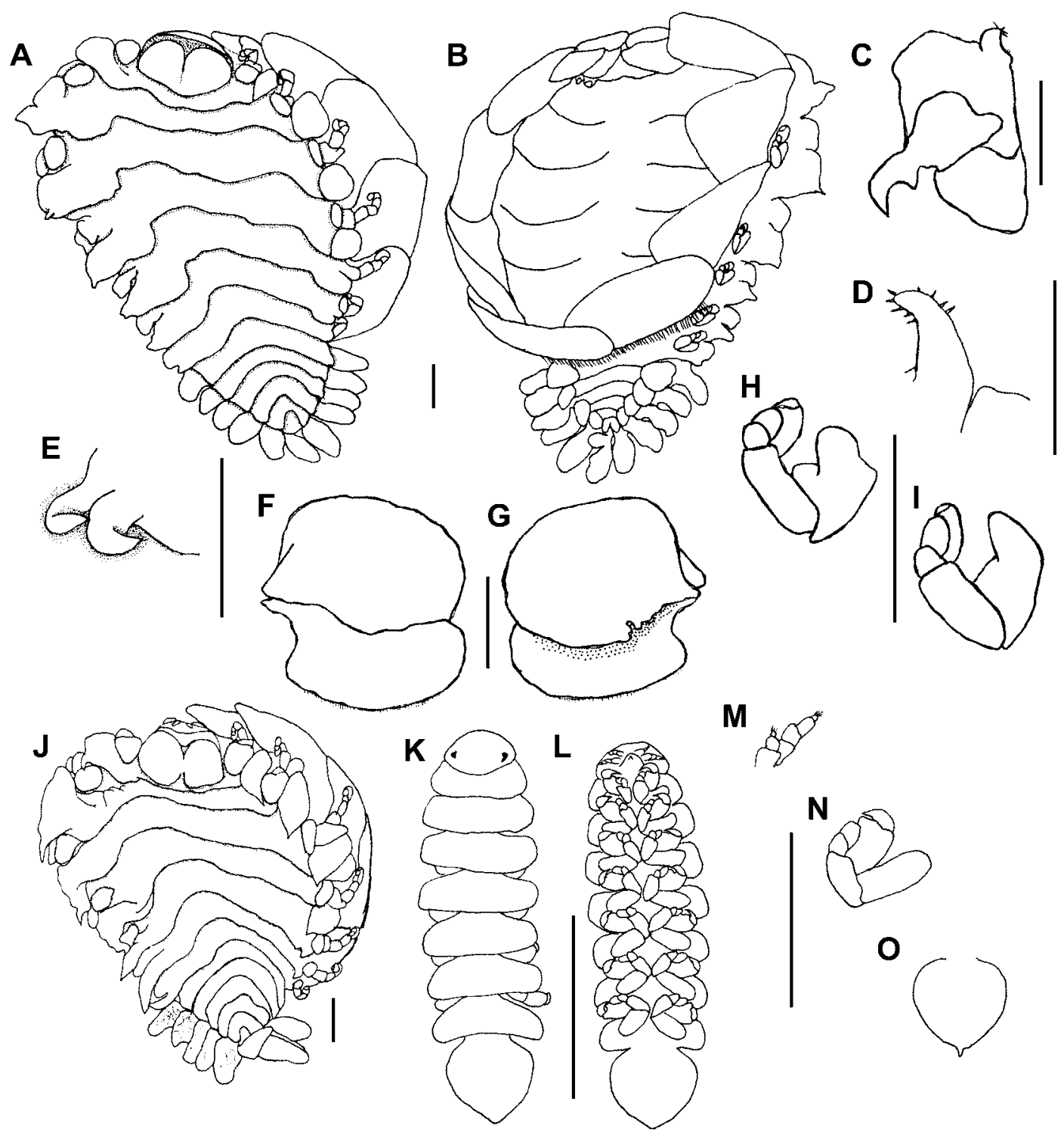

Fig. 1. Argeia pugettensis Dana, 1852, female (CIECR007601) (A-I): A. Dorsal view. B. Ventral view. C. Right maxilliped, external view. D. Palp of right maxilliped. E. Right side of barbula. F. Right oostegite 1, external view. G. Right oostegite 1, internal view. H. Right pereopod 7. I. Right pereopod 1. Female (CIECR530401). J. Dorsal view. Male (CIECR007601) (K-N): K. Dorsal view. L. Ventral view. M. Antenna and antennule. N. Pereopod 7. Male (CIECR510401). O. Ventral view of pleon. Scale: $1 \mathrm{~mm}$ (AC, E-L, O), $0.5 \mathrm{~mm}(\mathrm{D}, \mathrm{M}, \mathrm{N})$.

head length $0.20 \mathrm{~mm}$, pleonal length 0.55 mm. (fig. 1K, L). Head elliptical, separated from first pereomere (fig. 1K). Black eyes near posterior edge of head (fig. 1K). Antennule of three articles, antenna of four articles, terminally setose (fig. $1 \mathrm{M}$ ). Pereomeres distinct, subequal in width, midventral projections lacking (fig. 1L). Dactyli of first pereopod larger others (fig. 1N). Pleon fused into single ovate piece, pleopods and uropods lacking; anal cone usually lacking (occasionally present) (fig. 1O). 
VARIATIONS: The head of some females is so deeply biobed it looks like a pair of spheres united. One female specimen (CIECR530401) with an extremely bulging head, very extended, terminally sharp tergal projections (fig. 1J) and the surface of the lateral plates are crenulated. One male (CIECR510401) with anal cone on the terminal end of the pleon (fig. 1O).

Hosts AND Localities: Infesting Argis alaskensis (Kingsley, 1883), Argis crassa (Rathbun, 1899), Argis dentata (Rathbun, 1902), Argis lar (Owen, 1839), Argis ovifer (Rathbun, 1902), Crangon affinis De Haan, 1849, Crangon alaskensis Lockington, 1877, Crangon alba Holmes, 1900, Crangon cassiope de Man, 1906, Crangon crangon (Linnaeus, 1758), Crangon dalli Rathbun, 1902, Crangon franciscorum Stimpson, 1856, Crangon franciscorum angustimanus Rathbun, 1902, Crangon hakodatei Rathbun, 1902, Crangon nigromaculata Lockington, 1877, Crangon propinquus Stimpson, 1860, Eualus suckleyi (Stimpson, 1854), Lissocrangon stylirostris (Holmes, 1900), Mesocrangon munitella (Walker, 1898), Metacrangon munita (Dana, 1852), Neocrangon communis Rathbun, 1899, Neocrangon resima (Rathbun, 1902), Neocrangon sagamiensis (Balss, 1913) (Crangonidae), Bering Sea to San Diego, Japan, Korea, China.

REMARKs: This species has an extremely wide range, occurring in both the northeast and northwest Pacific on at least 23 crangonid hosts. Specimens from Japan, Korea, and China have been well described, but northwestern Pacific specimens are much more poorly known. Richardson (e.g., 1905b) described the species in some detail, but a fuller redescription, especially of characters now known to be informative at the species level, is needed. An example of a possible difference between northwestern and northeastern Pacific specimens, based on literature review, is that the northwestern specimens appear to have moderate to pronounced bilobation of the head, while northeastern specimens have a nearly flat head in dorsal view (see, e.g., Gifford, 1934). Additionally, given the wide geographic range of the species, a molecular analysis of specimens from both sides of the Pacific should be undertaken to test the possibility of cryptic species.

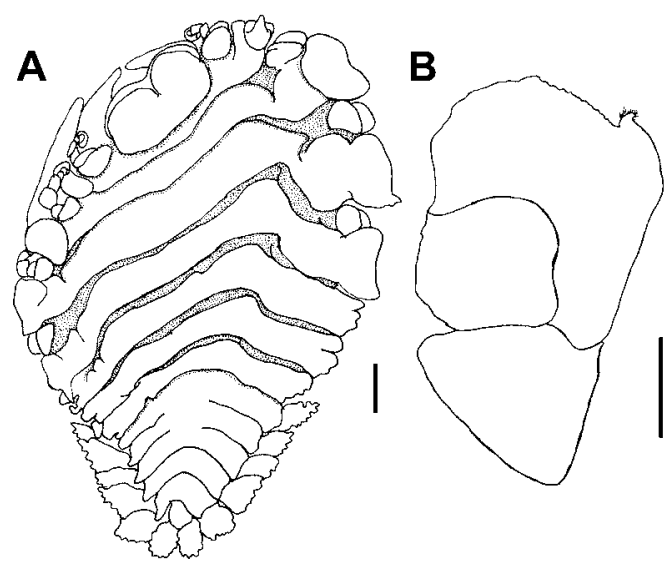

Fig. 2. Argeia sp., female(CIECR979401)(A-B): A. Dorsal view. B. Right maxilliped, external view. Scale: $1 \mathrm{~mm}$ (A); $0.5 \mathrm{~mm}$ (B).

There are three hosts of this species in China and one of these, Crangon cassiope, is the type host for Argeia pingi Yü, 1935, which was only very briefly described, not illustrated, and never reported subsequent to its original description. Markham (1977) thought $A$. pingi might be a synonym of $A$. pugettensis. Because this host has now been recollected and is infested with Argeia specimens that do not differ from $A$. pugettensis as currently defined, $A$. ping $i$ is here considered a synonym of A. pugettensis. However, if future moleculer and/or morphological analyses show any differences warranting recognition of the northeastern and northwestern populations as distinct species, $A$. ping $i$ would likely be the valid name for northwestern Pacific specimens, assuming that all northwestern Pacific specimens are conspecific. However, the type specimens of $A$. ping $i$ appear to be lost and a neotype would be required.

\section{Argeia sp. \\ Figure 2}

Argeia atlantica: An, 2006: 63-64; An et al., 2008: 226; An, 2011: 133-134, fig. 5-4 (not Argeia atlantica Markham,1977).

Material Examined: Infesting Crangon affinis De Haan, 1849, \& (CIECR979401), ơ (CIECR979402), Yellow Sea, Stn. 9794, $123^{\circ} 30^{\prime} \mathrm{E}, 35^{\circ} 30^{\prime} \mathrm{N}, 9$ January 2004. 
Description: Female (CIECR979401): Length $10.04 \mathrm{~mm}$, pereon length $4.46 \mathrm{~mm}$, maximal width $7.92 \mathrm{~mm}$, head length 0.92 $\mathrm{mm}$, head width $2.31 \mathrm{~mm}$ (fig. 2A).

All segments distinct except median regions of pleomeres 1 and 2. Anterior edge of head deeply bilobate, frontal lamina extending beyond head (fig. 2A); eyes lacking. Antennule and antenna of three and five articles, respectively, terminally setose. Maxilliped (fig. 2B) with setose palp, sharp plectron. Barbula with two pairs of simple falcate lateral projections on each side.

Pereon broadest across third pereomere (fig. 2A). Coxal plates, dorsolateral bosses and tergal projections enlarged on first four pereomeres. Tergal projections of pereomeres 3 and 4 acute and posteriorly directed. Brood pouch open. Oostegite 1 with nearly smooth internal ridge, without posterolateral point, posterior margin with setae. Posterior pereopods larger than anterior pairs, ischia without tubercles.

Pleon of six pleomeres, first five bearing lateral plates with serrated margins and uniramous smooth pleopods. Sixth pleomere without lateral plates, with uniramous uropods.

Description: Male (CIECR979402): Length $2.0 \mathrm{~mm}$, maximal width (across pereomere 4) $0.65 \mathrm{~mm}$, head width $0.41 \mathrm{~mm}$, head length $0.16 \mathrm{~mm}$, pleonal length $0.62 \mathrm{~mm}$. Head elliptical, separated from first pereomere; eyes present. Antennule and antennae of three and four articles, respectively. Pereomere segements distinct, subequal in width, midventral projections lacking. Pereopods subequal in size and shape. Pleon fused into single ovate piece, pleopods and uropods lacking.

REMARKs: The female specimen differs from typical $A$. pugettensis in that it has the ischium of each pereopod without any large tubercular swelling and the lateral plates of the pleon have serrated margins. The male is not obviously different from those of $A$. pugettensis. Earlier records of these specimens (An, 2006, 2011; An et al., 2008) identified the specimens as A. atlantica. Aside from the geographical distance between China and the western Atlantic, the Chinese specimens do not match $A$. atlantica as females of that species do not have serrated lateral plates and the head is flat (the head of the Chinese specimen, like those of $A$. pugettensis, is bilobed). Because this female lacks swellings on the ischia and has serrated lateral plates, it may represent an undescribed species. However, as it might also be an aberrant specimen of $A$. pugettensis, more material is needed for study.

\section{Stegoalpheon Chopra, 1923}

Diagnosis (modified from Markham, 1977): Female: body ovate, wider than long, slightly asymmetrical; head separated from pereon, large frontal lamina. Pereomeres distinct, all except first subequal in length, first shorter, sixth segment not shorter than others, coxal plates on segments 1-4; dorsolateral bosses indistinct, marsupium open. Oostegite 1with prominent posterolateral falcate points extending far beyond sides. Pleomere of 6 segments, distinct dorsally and laterally; segments 1-5 (sometimes 6) with dorsally directed lateral plates and biramous pleopods ventrally located and extending to sides of pleon. Uropods uniramous, similar to pleopods in shape.

Male: Head distinct from pereon, eyes large. Pereomeres well defined. Pleon with all segments fused, pleopods and uropods absent.

TyPe SPECIES: Stegoalpheon kempi Chopra, 1923 , by original designation.

OTHER SPECIES: None.

REMARKs: Chopra (1923) originally described Stegoalpheon kempi as having five pairs of triramous pleopods However, Shiino (1951) and Pillai (1966) convincingly showed that the dorsally directed lobes were lateral plates and that the pleopods were biramous. Markham (1977) stated that the type species has five pairs of uniramous lateral plates and five pairs of uniramous pleopods, but this is incorrect. There is clearly some variability in the number of lateral plates, as Chopra (1923) indicated five pairs, which argrees with the present material, while both Shiino (1951) and Pillai (1966) described specimens with six pairs.

\section{Stegoalpheon kempi Chopra, 1923} Figure 3

Stegoalpheon kempi Chopra, 1923: 462, 464 467, text fig. 8, pl. 13, fig. 1-7 [India, 

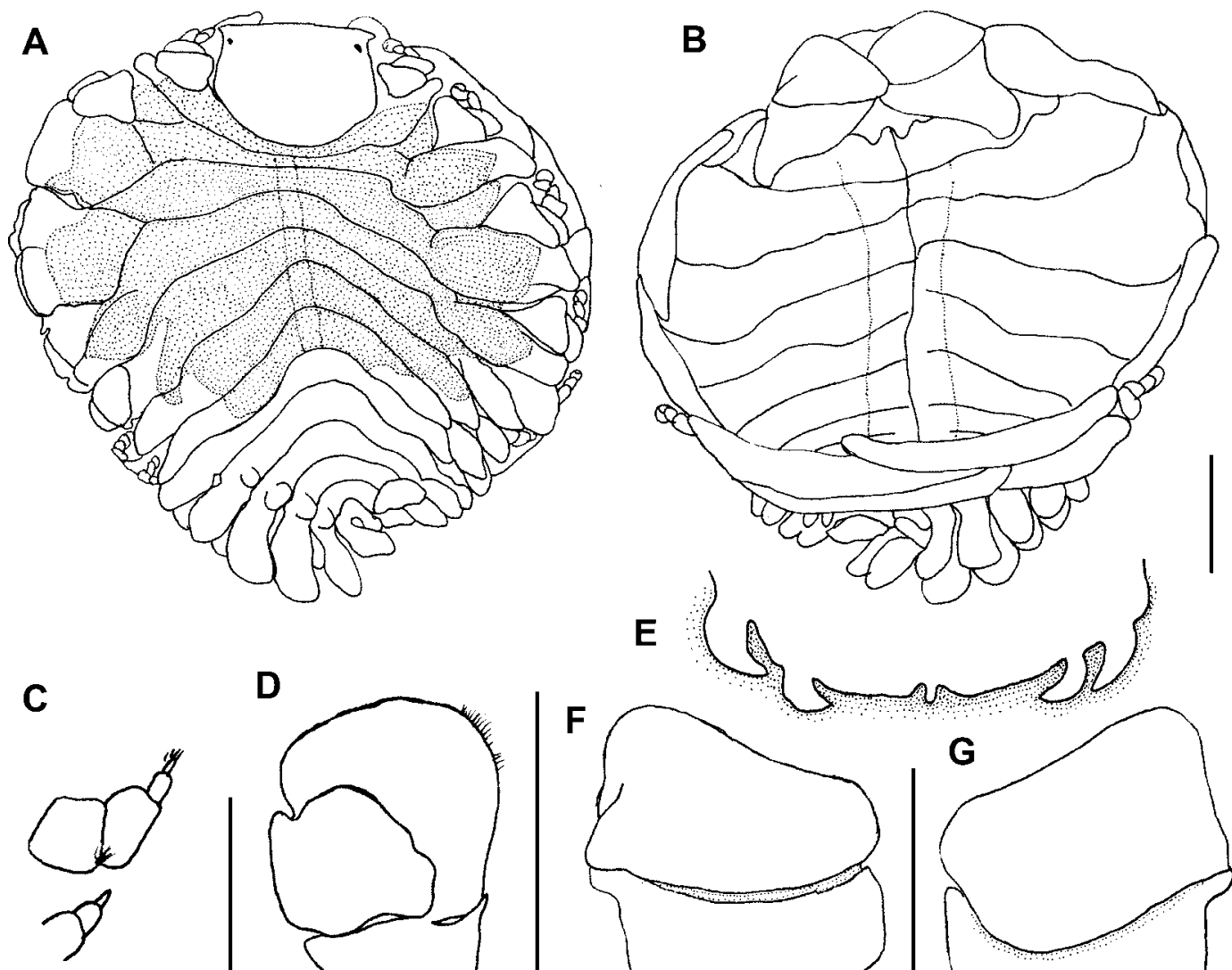

D

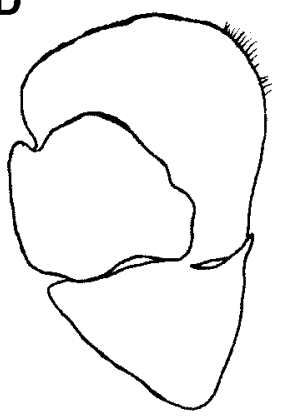

I

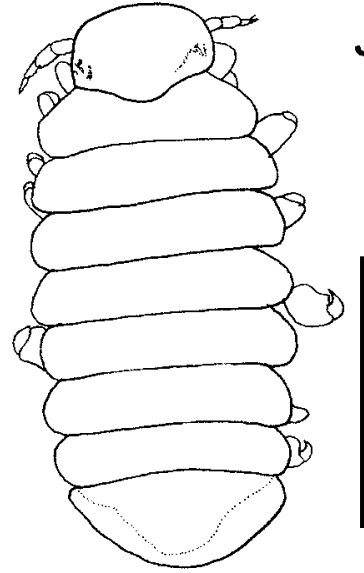

$F$
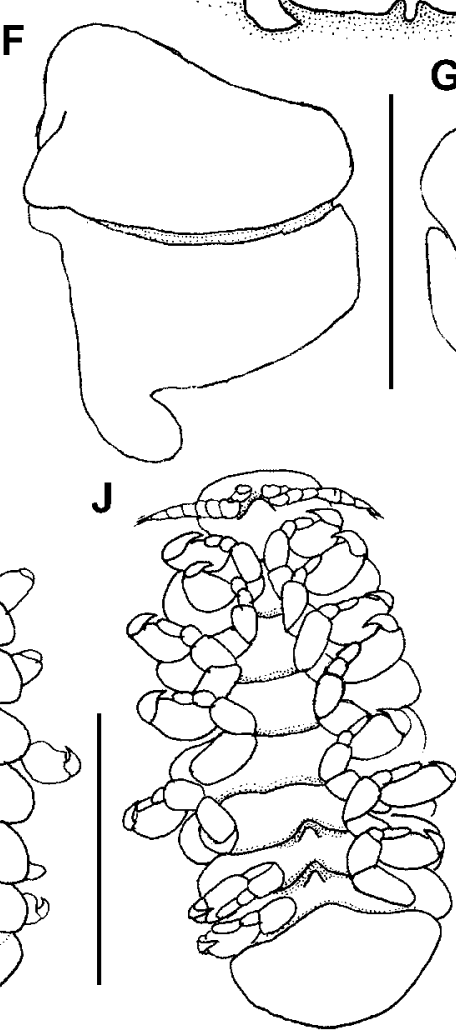

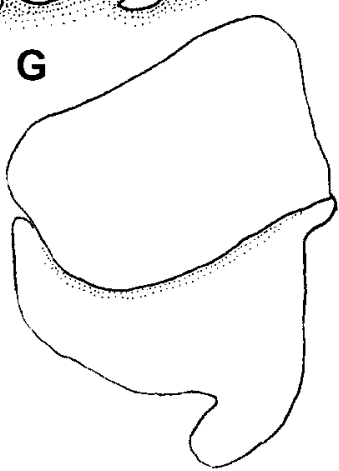

H

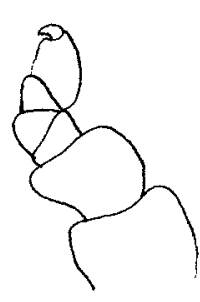

Fig. 3. Stegoalpheon kempi Chopra, 1923, female (CIEAL880701) (A-H): A. Dorsal view. B. Ventral view. C. Left antenna and antennule. D. Right maxilliped, external view. E. Barbula. F. Right oostegite 1, external view. G. Right oostegite 1, internal view. H. Right pereopod 2. Male (CIEAL880701) (I-K): I. Dorsal view. J. Ventral view. K. Antenna and antennule. Scale: $1 \mathrm{~mm}$ (A, B, D-G, $) 0.5 \mathrm{~mm}(\mathrm{H}-\mathbf{J}), 0.25$ $\mathrm{mm}(\mathrm{C}, \mathrm{K})$. 
infesting Alpheus cf. lobidens (De Haan, 1849)]; Shiino, 1951: 26-29, figs. 1-2 [Japan, infesting Alpheus rapax Fabricius, 1798]; Pillai, 1954: 20; Pillai, 1966: 188190, figs. 12-20 [India, infesting Alpheus sp.]; Shiino, 1958: 61 [Japan, infesting Alpheus rapax Fabricius, 1798]; Rao and Ramaprasad, 1964: 588-589, figs. 1-2 [India, infesting Alpheus malabaricus (Fabricius, 1775)]; Shiino, 1972: 8; Kannupandi, 1976: 87-93, figs. 1-3; Markham, 1977: 109-111, 119-120; Adkison et al., 1982: 337; Kensley, 2001: 226; An, 2006: 65-65, fig. 27; An et al., 2008: 225-226, fig. 2 [China, infesting Alpheus sp.]; Liu, 2008: 693; Williams and Boyko, 2010: 150; An, 2011: 134-136, figs. 5-5-5-7 [same material as An et al., 2008].

Stegoalpheon choprai Pillai, 1954: 20 [India, infesting Alpheus paludicola Kemp, 1915]; Rao and Ramaprasad, 1964: 588; Markham, 1977: 109, 111, 120; Kensley, 2001: 226; Williams and Boyko, 2010: 150.

Stegoalpheen [sic] kempi- Rao and Ramaprasad, 1964: 588 (figure caption).

Material Examined: Infesting Alpheus sp., 1 ㅇ, 1 o (CIEAL880701), Niuchelun Jiao of Nansha, $116^{\circ} 10^{\prime} \mathrm{E}, 9^{\circ} 36^{\prime} \mathrm{N}, 23$ July 1988; 1 , 1 o (CIEAL940901), Banyue Jiao of Nansha, $116^{\circ} 16^{\prime} \mathrm{E}, 8^{\circ} 52^{\prime} \mathrm{N}, 29$ September 1994.

Description: Female (CIEAL880701): Length $4.28 \mathrm{~mm}$, maximal width across pereomere $34.43 \mathrm{~mm}$, head length $0.88 \mathrm{~mm}$, head width $1.29 \mathrm{~mm}$, almost symmetrical (fig. 3A, B).

Body oval, length $3 / 4$ width. All segments distinct. Head pentagonal, frontal lamina obscure, but anterior margin of the head extended (fig. 3A). Black eyes on lateral corner of anterior margin of head. Antennule of three articles, antennae of four articles, terminally setose (fig. 3C). Maxilliped (fig. 3D) without palp, but tuft of setae indicating palp location. Plectron extend and sharp. Barbula (fig. 3E) with two pairs of falcate lateral projections on each side, one median small tubercle present.

Pereon broadest across third pereomere (fig. 3A). Coxal plates reduced, dorsolateral bosses on first five pereomeres. Tergal projections of pereomeres $2-4$ distinct. Brood pouch completely open (fig. 3B). Oostegite 1 with smooth internal ridge, posterolateral point rounded laterally (fig. 3F, G). Pereopods short, with blunt dactyli (fig. 3H). Pleon of six pleomeres, first five pleomeres with small, dorsally directed, tubercular lateral plates. Five pairs of biramous ovate pleopods, those on longer side of body much larger than those on shorter side (fig. 3B). Sixth pleomeres with uniramous uropods, similar in shape to pleopods.

Description: Male (CIEAL880701): Length $2.03 \mathrm{~mm}$, maximal width (across pereomere 4) $0.95 \mathrm{~mm}$, head width $0.52 \mathrm{~mm}$, head length $0.34 \mathrm{~mm}$, pleonal length $0.35 \mathrm{~mm}$ (fig. 3I, J). Head pentagonal, separated from first pereomere (fig. 3I). Irregular black eyes near postolateral corner of the head (fig. 3I). Antennule of three articles, antenna of seven articles, much longer than antennule, antennulae and antenna terminally setose (fig. 3K). Pereon much wider than head, segements distinct (fig. 3I), all subequal in width. Pereomeres 6 and 7 with midventral projections (fig. 3J). First four pereopods larger than last three, dactyli of first two larger than others (fig. 3J). Pleon fused into single piece, without any pleopods or uropods (fig. 3J).

Hosts and Localities: Infesting Alpheus cf. lobidens (De Haan, 1849), Alpheus malabaricus (Fabricius, 1775), Alpheus paludicola Kemp, 1915, Alpheus rapax (Fabricius, 1798), Alpheus sp. (Alpheidae), India, Japan, China.

Remarks: As pointed out by Williams and Boyko (2010), Stegoalpheon choprai was synonymized with $S$. kempi by Pillai (1966), despite later (Markham, 1977; Kensley, 2001) citations of the species as valid. The present females conform well with Chopra's (1923) holotype although with much smaller dorsally directed lateral plates; however, the present male possesses midventral projections on the last two pereomeres and a wider pereon (allotype male without any midventral projections and a pereon subequal in width compared to the head).

\section{Pseudioninae Codreanu, 1967}

Diagnosis: Female: All body segments distinct, head usually fused with frontal lamina. Pereon with coxal plates, dorsolateral bosses, 
and tergal projections. Pleopods usually biramous, uropods present.

Male: Head separated from first pereomere, or fused on posterior edge. All pereomeres distinct, often with midventral tubercles. Pleon with one (fused) or six distinct pleomeres, usually with tubercular or flaplike pleopods on first five pleomeres. Uropods sometimes present.

Remarks: Pseudioninae is largest and most heterogeneous subfamily in Bopyridae, includes 48 genera and 236 species, and may not be monophyletic (Williams and Boyko, 2012). Some species possess putatively primitive characters, such as males having lateral plates on the pleon and well-developed pleopods. All species are branchial parasites and most species infest anomurans, axiideans, and gebiideans, with relatively few being found on carideans and brachyurans.

\section{Paranikione, n. gen.}

Diagnosis: Female: Body asymmetrical. Head wider than long, with well-developed frontal lamina. Barbula with two pairs of smooth lateral projections. All pereomeres with coxal plates, first four with dorsolateral bosses. Brood pouch open; internal ridge of oostegite 1 smooth. Pleon with six segments, five pairs of pleopods and tuberculate biramous uropods.

Male: Body segments distinct, pereomeres subequal in width, pleon with five pairs of tuberculate pleopods, sixth pleomere with posterolateral uropods.

TyPe SPecies: Paranikione sibogae, n. sp., by original designation.

OTHER SPECIES: Paranikione distorta, n. sp.

Etymology: Paranikione refers to the close relationship of the new genus to Nikione Kensley, 1974. The genus name is feminine.

Remarks: Females of both species of Paranikione, n. gen., have a well-developed frontal lamina, coxal plates on all pereomeres and pleomeres, and biramous pleopods and uropods. These two species are allied to the monotypic genera Nikione and Urobopyrus Richardson, 1904, which also infest processid shrimp. The new genus is most closely related to Nikione, but differs in that females of Nikione have only five pleomeres while those of Paranikione, n. gen., have six distinct pleomeres. The key characteristic of Urobopyrus is that the female has no lateral plates on the pleomeres, but species of Paranikione, n. gen., have well-developed lateral plates on all pleomeres.

\section{Paranikione sibogae, n. sp.} Figure 4

Urobopyrus processae: An, 2006: 69-70, fig. 29 (not Urobopyrus processae Richardson, 1904).

Material Examined: Infesting Nikoides sibogae de Man, 1918. Holotype o (CIEPR 615401) and allotype ot (CIEPR615402), South China Sea, Stn. 6154, $110^{\circ} 45^{\prime} \mathrm{E}$, $19^{\circ} 15^{\prime} \mathrm{N}, 38 \mathrm{~m}, 10$ July 1959 , coll. Fengshan Xu. Paratypes: 1 \%, 1 ơ (CIEPR603001), South China Sea, Stn. 6030, $115^{\circ} 30^{\prime} \mathrm{E}$, $21^{\circ} 30^{\prime} \mathrm{N}, 115 \mathrm{~m}, 13$ April 1960, coll. Jingzuo Qu.

Other Material: 1 o, 2 ơo (CIEPR 607701), South China Sea, Stn. 6077, $113^{\circ} 00^{\prime} \mathrm{E}, 21^{\circ} 00^{\prime} \mathrm{N}, 54 \mathrm{~m}, 21$ April 1959, coll. Fuzeng Sun; 1 ㅇ, 1 đ (CIEPR615901), South China Sea, Stn. 6159, $110^{\circ} 30^{\prime} \mathrm{E}$, $18^{\circ} 45^{\prime} \mathrm{N}, 31 \mathrm{~m}, 6$ May 1960, coll. Shoupeng Shen.

DesCRIPTION: Holotype female (CIEPR 615401): Length $4.39 \mathrm{~mm}$, maximal width $4.54 \mathrm{~mm}$, head length $0.69 \mathrm{~mm}$, head width $1.32 \mathrm{~mm}$, sinistral body shape, distorted $23^{\circ}$ (fig. 4A, B). Body wider than long, left side longer than right, all segments distinct. Head elliptical with bilobate anterior margin, well-developed frontal lamina extending beyond head. Eyes absent (fig. 4A). Antennule of three articles, antenna of five articles, setae not observed. Maxilliped rectangular, with stout and short palp bearing three stout setae distally (fig. 4D). Barbula with two pairs of smooth falcate lateral projections on each side, median pair of small trianglular projections near center (fig. 4D).

Pereon broadest across third pereomere. First four pereomeres with dorsolateral bosses, all pereomeres with coxal plates. Coxal plates of left side larger than right (fig. 4A). Brood pouch widely open (fig. 4B). Oostegite 1 (fig. 4E, F) with smooth internal 

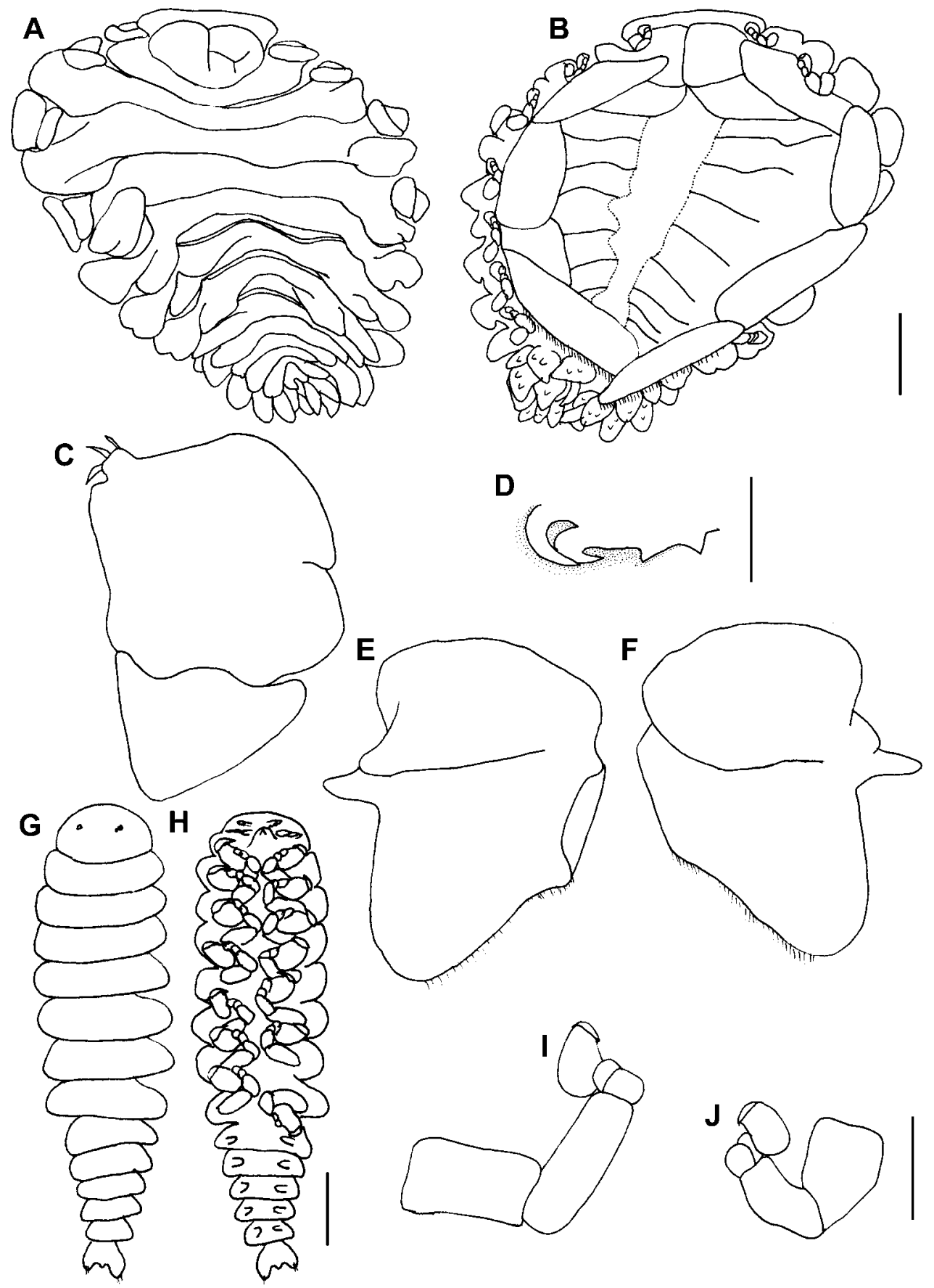

Fig. 4. Paranikione sibogae n. gen., n. sp., holotype female (CIEPR615401) (A-F): A. Dorsal view. B. Ventral view. C. Left maxilliped, external view. D. Right side of barbula. E. Right oostegite 1, external view. F. Right oostegite 1, internal view. Allotype male (CIEPR615402) (G-J): G. Dorsal view. H. Ventral view. I. Pereopod 1. J. Pereopod 7. Scale: $1 \mathrm{~mm}$ (A, B); $0.5 \mathrm{~mm}$ (C-F); $0.25 \mathrm{~mm}$ (G-J). 
ridge, posterolateral point round, laterally directed, mesiolateral margin setose. Posterior pereopods larger than anterior pairs, carpi and meri smooth, bases of all pereopods produced into smooth lobes. Pleon of six pleomeres, lateral plates well developed. First five pleomeres with biramous pleopods and lateral plates, sixth pleomeres with biramous uropods. Surface of pleopods and uropods tubercular (fig. 4B).

DESCRIPTION: Allotype male (CIEPR 615402): Length $1.50 \mathrm{~mm}$, maximal width across pleomere $40.44 \mathrm{~mm}$, head width 0.28 $\mathrm{mm}$, head length $0.16 \mathrm{~mm}$. All pereomeres distinctly segmented (fig. 4G, H). Head semicircular (fig. 4G), dark eyes medially (fig. 4G). Antennule of three articles, with setae on distal article, antenna of five articles, terminally setose (fig. 4H). All pereomeres subequal in width, midventral projections lacking (fig. 4H). First two pereopods each with slightly larger dactylus and longer ischium (fig. 4I, J) than other pereopods. Pleon of six segments, midventral projections lacking, five pleomeres with small tubercular pleopods. Sixth pleomere (pleotelson) with medial anal cone and pair of distolateral uropods with setose terminal margins (fig. $4 \mathrm{H}$ ).

VARIATION: The paratype female agrees with the holotype in most characters, but is weakly tubercular on the surface of the head and sinistral at $39^{\circ}$. Two immature males (CIEPR607701) are attached to the pleomere of this female. Another female (CIEPR615901) has a white body, as opposed to the typical preserved tan coloration, but this may be an artifact of preservation.

Eтymology: The specific name, sibogae, refers to the host name and honors the Dutch Siboga Expedition to Indonesia (March 1899February 1900) on which bopyrid researcher Hugo Frederik Nierstrasz (1872-1937) served as zoologist. The species is feminine because ships names are considered female.

Host AND Locality: Infesting Nikoides sibogae de Man, 1918 (Processidae), South China Sea, 38-54 m.

ReMARKs: See the generic diagnosis for discussion of the differences between this species and those in Nikione and Urobopyrus and Remarks under Paranikione distorta, n. sp., for the differences between the two species in the new genus.

Paranikione distorta, n. sp. Figure 5

Urobopyrus bicornis An, 2006: 70-71, fig. 30 (unavailable name).

Material Examined: Infesting Hayashidonus japonica (De Haan, 1844). Holotype 우 (CIEPR010801), allotype ơ (CIEPR010802), eastern Yellow Sea, Stn. 0108, $122^{\circ} 45^{\prime} \mathrm{E}$, $31^{\circ} 15^{\prime} \mathrm{N}, 94 \mathrm{~m}, 15$ August 1964, coll. unknown. Paratypes: 1 o, 1 ๙ (CIEPR601201), Shantou, Guangdong Province, Stn. $6012,117^{\circ} 00^{\prime} \mathrm{E}, 22^{\circ} 30^{\prime} \mathrm{N}, 47.3 \mathrm{~m}$, 23 December 1959, coll. Yu.

Other Material: 1 \%, 1 ơ (CIEPR625401), Beibu Gulf, Stn. 6254, $107^{\circ} 30^{\prime} \mathrm{E}, 18^{\circ} 30^{\prime} \mathrm{N}$, 63.9 m, 10 July 1960, coll. Zhengang Fan.

DESCRIPTION: Holotype female (CIEPR 010801): Length $5.15 \mathrm{~mm}$, maximal width $4.96 \mathrm{~mm}$, head length $0.82 \mathrm{~mm}$, frontal lamina $0.22 \mathrm{~mm}$, head width $1.37 \mathrm{~mm}$, pleon length $1.38 \mathrm{~mm}$, sinistral $67^{\circ}$ (fig. 5A, B).

Head triangular, frontal lamina extending beyond sides of head and produced into earlike lamellae at anterolateral corners. Eyes absent (fig. 5A). Antennule of three articles, antenna of four articles, both terminally setose (fig. 5C). Maxilliped of two segments with short stout nonarticulated palp (fig. 5D), terminal end of palp and adjacent margin fringed with setae (fig. 5E). Barbula with two pairs of smooth falcate lateral projections on each side (fig. 5F).

Pereon broadest across third pereomere (fig. 5A), boundary between pereomeres 2-4 obscure, weakly fused. All pereomeres with coxal plates, those on left side much larger than right. Dorsolateral bosses on first four pereomeres. Brood pouch widely open (fig. 5B). Oostegite 1 visible from ventral view (fig. 5B), two articles subequal in length, smooth internal ridge and nearly straight posterior edge (fig. 5G, H). Pereopods smaller posteriorly (fig. 5I, J), each with five articles, carpi and meri fused, dactyli small. Pleon of six pleomeres, medially fused and sharply distorted sinistrally. First five pleomeres with biramous pleopods and lateral plates. Lateral plates of left side larger than right. Sixth 

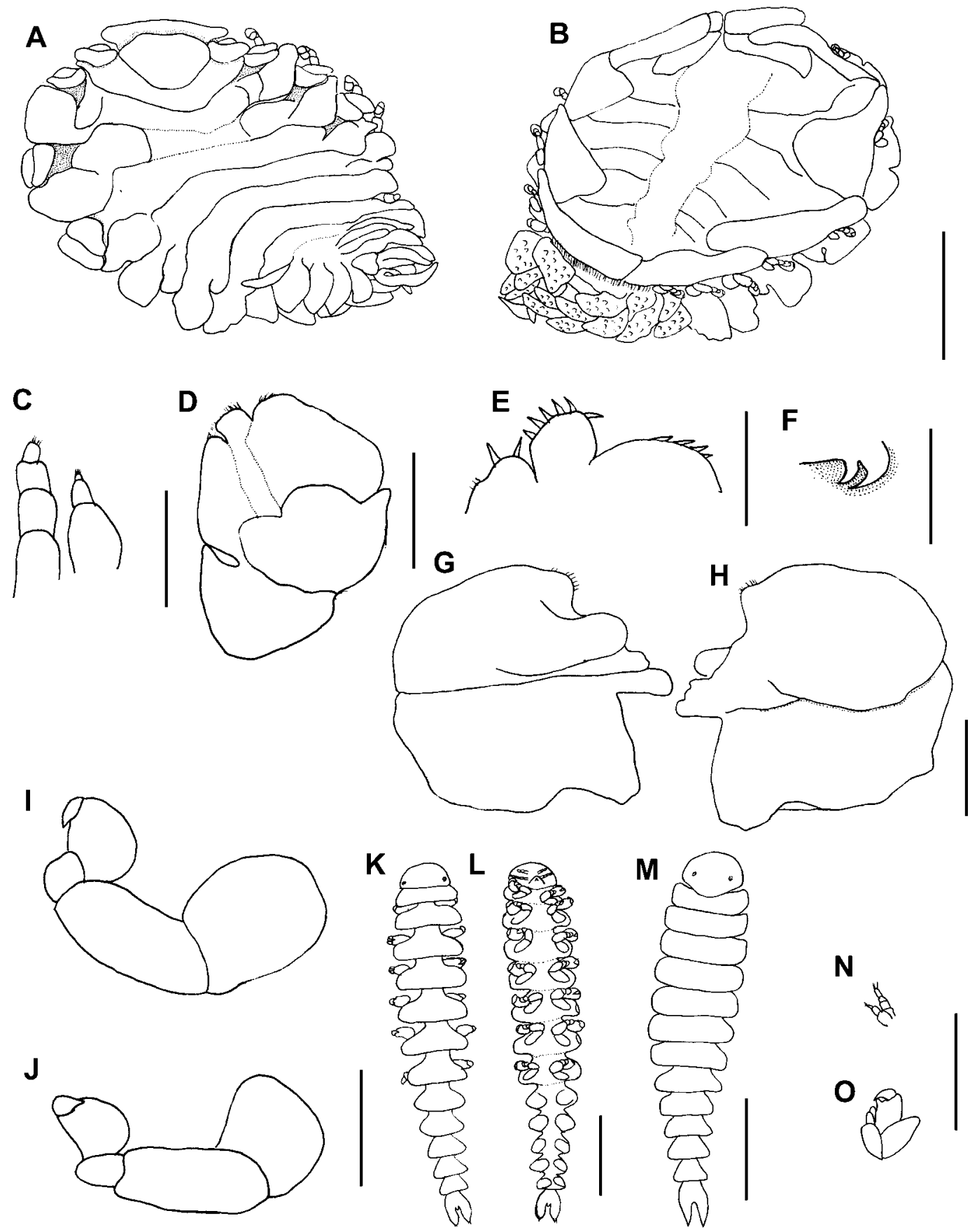

Fig. 5. Paranikione distorta n. sp., holotype female (CIEPR010801) (A-J): A. Dorsal view. B. Ventral view. C. Right antenna and antennule. D. Right maxilliped, external view. E. Palp of maxilliped. F. Left side of barbula. G. Left oostegite 1, external view. H. Left oostegite 1, internal view. I. Left pereopod 4. J. Left pereopod 6. Allotype male (CIEPR010802) (K, L, N, O): K. Dorsal view. L. Ventral view. M. Male (CIEPR601201) dorsal view. N. Left antenna and antennule. O. Left pereopod 5. Scale: 2 mm (A, B); 0.5 mm (D, F-H, K-M, ; 0.25 mm (C, E, I, J, N, O). 
pleomere with lobate biramous uropods. Ventral surface of pleopods thickly tubercular (fig. 5B), but uropods nearly smooth and lanceolate.

DesCRIPTIOn: Allotype male (CIEPR010 802): Length $2.15 \mathrm{~mm}$, maximal width (across pleon 4) $0.38 \mathrm{~mm}$, head width $0.31 \mathrm{~mm}$, pleotelson length $0.83 \mathrm{~mm}$. All pereomeres distinctly segmented (fig. 5K, L). Head semicircular (fig. 2K); dark eyes in posteriolateral corners (fig. 5K). Antennule of three articles, antenna of four articles, terminal articles setose (fig. 5N). Pereomeres subequal in width, midventral projections lacking (fig. 5L). All pereopods with six articles and subequal in size (fig. 5O). Pleon of six segments, first five pleomeres with large tubercular pleopods. Sixth pleomere with minute medial anal cone and long posteriorly directed tapering uropods (fig. 5L), distal tips of uropods with setae.

VARIATION: The paratype female (CIEPR60 1201) agrees with the holotype, but the antennae can be seen in dorsal view, and the median part of the pereon bulges outward. The paratype male (CIEPR601201) has a curved posterior margin of the head and its uropods are longer than those of the allotype (fig. 2M). The other female (CIEPR625401) is much larger (total length $6.09 \mathrm{~mm}$ ) and has a wider frontal lamina and longer pleopods than the types.

ETymology: The specific name, distorta, refers to the sharply sinistrally distorted pleon of the female.

Host And Localties: Infesting Hayashidonus japonica (De Haan, 1844) (Processidae). Yellow Sea, Beibu Gulf, and Guangdong Province, China, 47-94 m.

Remarks: Paranikione distorta, n. sp., has a well-developed frontal lamina, pleon of six segments, lateral plates of the pleon lamellar, and is clearly congeneric with Paranikione sibogae, $\mathrm{n}$. sp. The new species differ from $P$. sibogae, n. sp., in having (1) median part of female pleon fused, (2), female lacking acute median projections on the barbula, (3) female with sharply distorted pleon, (4) pereopods of the female with carpi and meri fused, (5) male with large tubercular pleopods and (6) male with long posteriorly directed uropods.

\section{Pseudione Kossmann, 1881}

Diagnosis (after Markham, 1985a): Female: Body oval or pyriform; all segments distinct. Frontal lamina moderately developed. Coxal plates reduced; oostegite 1 with rounded posterolateral point. Six pleomeres, first five produced into moderately to greatly developed lateral plates; pleopods biramous, lanceolate; uropods usually uniramous, lanceolate.

Male: Body smoothly tapered anteriorly and posteriorly from midpoint (pleon occasionally abruptly wider or narrower than final pereomere); all body regions distinct. Pereopods subequal, anterior pereopods not markedly larger than others. Pleon $1 / 5$ to $1 / 3$ of total body length, of six pleomeres (specimens of some species with pleomeres variously fused and pleons proportionately shorter); pleopods uniramous, tuberculiform to flaplike; no uropods, posterior border of terminal pleomere slightly to greatly produced into posterolateral points.

Type Species: Pseudione callianassae Kossmann, 1881, by monotypy.

Species Hosted by Carideans: Pseudione affinis (G. O. Sars, 1883), P. ampla Markham, 1988, P. clevai Boyko, 2004, P. cognata Markham, 1985, P. elongata africana Kensley, 1968, $P$. elongata elongata (Hansen, 1897), P. indica Chopra, 1930, P. magna Shiino, 1951, P. parviramus Adkison, 1988, P. pontocari Page, 1985, P. stylopoda Boyko, 2004,

Remarks: The remainder of the 53 species and subspecies of Pseudione are parasites of anomurans (26 species), axiideans (10 species), nephropids (3 species), a brachyuran (1 species) and one from an unknown host. The genus is likely paraphyletic, but the type species is very poorly known.

\section{Pseudione tattersalli Nierstrasz and Brender à Brandis, 1923}

Pseudione tattersalli Nierstrasz and Brender à Brandis, 1923: 72, 74-76, pl. 5, fig. 8, pl. 9, fig. 36 [Indonesia, infesting unknown host]; Nierstrasz and Brender à Brandis, 1931: 167; Danforth, 1963: 10; Danforth, 1970: 3; Danforth, 1971a: 101; Bourdon, 1972a: 108-110, fig. 3 [Indonesia, infesting Plesionika ensis (A. Milne Edwards, 1881)]; 
Adkison, 1988: 577-578; Høeg and Rybakov, 1992: 604; Markham, 1985a: 14; Boyko, 2004: 678, fig. 1 [Taiwan, infesting Plesionika fimbriata Chace, 1985].

Material Examined: None.

Hosts and Localities: Infesting Plesionika ensis (A. Milne Edwards, 1881) and Plesionika fimbriata Chace, 1985 (Pandalidae), Taiwan, Indonesia.

Remarks: Nierstrasz and Brender à Brandis (1923) did not know the identity of the type host; this was later determined by Bourdon (1972a).

\section{Bopyrinae Rafinesque, 1815}

Diagnosis: Female: Head usually fused with first pereomere, frontal lamina absent. Pereomeres often distinct, coxal plates and dorsolateral bosses reduced. Brood pouch often partly or widely open. Pleomeres distinct or fused at least on one side, without lateral plates or uropods. Pleopods smooth, biramous or uniramous.

Male: Head often fused with first pereomere, other pereomeres distinct. Pleon usually fused into single piece, pleopods and uropods often reduced.

RemARKs: Bopyrinae contains 27 genera and 122 species (Boyko, 2014; herein). All are branchial parasites of caridean shrimps.

\section{KEY TO THE 27 GENERA OF BOPYRINAE, BASED ON FEMALE CHARACTERS (MODIFIED FROM MARKHAM, 1985a)}

1a. Pleon sharply rotated, with posterior edge pointing forward . Bathygyge Hansen, 1897

1b. Pleon extending straight back or nearly so .. 2

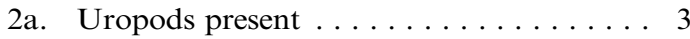

2b. Uropods absent . . . . . . . . . . . 5

3a. Biramous uropods, with long, thin rami ........ Urobopyrus Richardson, 1904

3b. Uniramous uropods, long and wide . . . . 4

4a. Maxilliped without palp. ........... ... . . . . . Litobopyrus Markham, 1982

4b. Maxilliped with setose palp . . . . . . . . ........ Parapleurocrypta Chopra, 1923

5a. Pleopods reduced ............6 6

5b. Pleopods well developed $\ldots \ldots \ldots \ldots \ldots 7$ 6a. Pleopods of one side reduced ......... ... . . . Palaemonellione Markham, 1989

6b. All pleopods reduced .............. . . . . . . . . Ogyridione Markham, 1988

7a. Biramous pleopods . . . . . . . . . 8

7b. At least some uniramous pleopods . . . . . 14

8a. Head distinctly extended into anterolateral horns ... . . . Capitetragonia Pearse, 1953 (= Probopyria Markham, 1985)

8b. Head not anterolaterally extended ..... 9

9a. Head and pereon separate . . . . . . . . 10

9b. Head and pereon fused at least medially 13

10a. Body subcordate (heart shaped), barbula with two pairs of projections . . . . . . . . ... . Probopyrus Giard and Bonnier, 1888

10b. Body not cordate, barbula with single pair

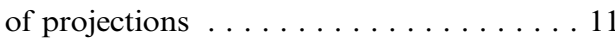

11a. Oostegite 1 without posterolateral point . . . . ......... Parabopyriscus Markham, 1982

11b. Oostegite 1 with posterolateral point . . . 12

12a. Pleon of six distinct pleomeres well separated laterally .... Probopyriscus Markham, 1982

12b. Pleon of six pleomeres separated on long side only . . . . . . . . Probopyrinella

Nierstrasz and Brender à Brandis, 1929

13a. Pleomeres of at least one side fused ....... ......... Bopyrella Bonnier, 1900

13b. Pleomeres distinct on both sides . . . . . . . ....... Parabopyrella Markham, 1985

14a. First three pleopods biramous, fourth uniramous ...... Allobopyrus Bourdon, 1983

14b. All pleopods uniramous .......... 15

15a. Five pairs of pleopods .......... 16

15b. Fewer than five pairs of pleopods .... 23

16a. Five pairs of oostegites . . . . . . . . 17

16b. Seven pairs of oostegites .......... .......... Septembopyrina, n. gen.

17a. Coxal plates absent . . . . . . . . . . . ......... Probopyrione Bourdon, 1983

17b. Coxal plates present . . . . . . . . 18

18a. Coxal plates on pereomeres $1-4 \ldots 19$

18b. Coxal plate on pereomeres $2-4 \ldots . . .22$

19a. Pleopods rudimentary, represented by illdefined tubercles . . Bopyroides Stimpson, 1864

19b. Pleopods flaplike, not rudimentary . . . . 20

20a. Body ovate . . Discorsobopyrus Boyko, 2004

20b. Body elongate . . . . . . . . . . . 21

21a. First pair oostegites symmetrical . . . . . . . . . . . . . . . Bopyrus Latreille, 1802

21b. First pair oostegites asymmetrical . . . . . . ......... Bopyrinella Nierstrasz and Brender à Brandis, 1925 22a. Pleomeres fused ... Parabopyrus Shiino, 1934 
22b. Pleomeres distinct .......... Probynia Bourdon and Bruce, 1983

23a. Pleomeres laterally extended, digitate . . . . .......... Bopyrinina Shiino, 1933

23b. Pleomeres rounded laterally . . . . . . . 24

24a. Pleomeres fused on one side. . . . . . . . . .......... Bopyrina Kossmann, 1881

24b. Pleomeres distinct on both sides . . . . . 25

25a. Oostegite 1 of left and right side asymmetrical ... . Schizobopyrina Markham, 1985

25b. Oostegite 1 of left and right side symmetrical .............. 26

26a. Head fused with first pereomere at least medially . . . . . . . Synsynella Hay, 1917

26b. Head separate from first pereomere . . . . .

. Bopyrione Bourdon and Markham, 1980

\section{Bathygyge Hansen, 1897}

Diagnosis (after Markham, 1985a): Female: Body subcircular. Coxal plates large; oostegites about half covering marsupium. Small pleon sharply rotated, of six distinct separated pleomeres, lacking lateral plates, pleopods and uropods biramous.

Male: All pereomeres distinct. Propodus of each pereopod produced into ventrodistal projection receiving tip of dactylus. Pleon fused, ovate, bulbous, about 1/4 total body length, lacking appendages and most traces of segmentation.

TYPe SPECIES: Bathygyge grandis Hansen, 1897 , by monotypy.

Other Species: None.

\section{Bathygyge grandis Hansen, 1897}

Figure 6

Bopyrus Faxon, 1895: 140 [material described by Hansen, 1897].

Bathygyge grandis Hansen, 1897: 122-124, pl. 6 , fig. 2 [off Nayarit, Mexico, infesting Glyphocrangon spinulosa Faxon, 1893]; Richardson, 1899a: 869; Richardson, 1899b: 338; Richard, 1900: 71; Bonnier, 1900: 8, 48, 221, 291-292, 381, text fig. 53; Richardson, 1905b: xx, xlvi, 537-539, 720, fig. 581; Stebbing, 1908: 38, 57-59, 94, pl. 7 (33) [South Africa, infesting Glyphocrangon sculpta (Smith, 1882)]; Stebbing, 1910a: 436, pl. 7 [South Africa, infesting G. sculpta]; Nierstrasz and Brender à Brandis, 1923: 86; Barnard, 1940: 494; Danforth,
1963: 33, 37, 91, 92, pl. 5, figs. 1-2; Sadoğlu, 1969: 197; Schultz, 1969: 312, fig. 496; Danforth, 1970: 9, 43, 57-58, 149, fig. 5d, e; Holthuis, 1971: 285; Wenner, 1978: 1058 [Middle Atlantic Bight, infesting G. sculpta and Glyphocrangon longirostris (Smith, 1882)]; Bourdon, 1979c: 510; Markham, 1979: 771-772; Markham 1985a: 19-20, 131 [Virginia, infesting G. sculpta and $G$. longirostris]; Markham, 1986: 155-156, fig. 4B; Markham, 1988: 57; Kaufmann et al., 1989: 1882 [Magellan Rise, NE Pacific, infesting Glyphocrangon vicaria Faxon, 1896 (the only Glyphocrangon listed)]; Salazar-Vallejo and Leija-Tristán, 1990: 429; Leija-Tristán and Salazar-Vallejo, 1991: 1; Markham, 1992b: 3; Espinosa-Pérez and Hendrickx, 2001: 50; Román-Contreras and Soto, 2002: 379; An, 2006: 67-68, fig. 28; An et al., 2007a: 1002-1003, fig. 1 [East China Sea, infesting G. megalophthalma de Man, 1918]; Liu, 2008; 691; Román-Contreras, 2008: 93; An, 2011: i, iv, 138-140, figs. 1-1, 5-8-5-10 [East China Sea, infesting $G$. megalophthalma].

? Bathygyge sp. Bourdon, 1967c: 857 [Canary Islands, infesting Glyphocrangon sp., parasite misidentified as Gigantione bouvieri Bonnier, 1900, by Richardson; hyperparasitized by Rolandoniscus serratus (Bourdon, 1967) (Cabiropidae)]; Lemos de Castro, 1970: 2; Restivo, 1971: 71; Restivo, 1975: 153; Bourdon, 1979c: 510 [Azores, infesting G. longirostris]; Bourdon et al., 1981: 498; Rybakov, 1990: 415.

? "bopyrid parasites" Holthuis, 1971: 339 [Nigeria, infesting G. longirostris].

? Munidion sp. Wicksten, 1979: 222 [San Clemente Basin, California, infesting $G$. vicaria]; Wicksten, 2008: 164 [not Munidion sp.].

? "branchial bopyrid" Chace, 1984: 11 [West of Halmahera, Indonesia, infesting Glyphocrangon faxoni de Man, 1918], 20 [Philippines, infesting Glyphocrangon pugnax de Man, 1918].

Bathygege [sic] grandis Campos and Rosa de Campos, 1989: 33.

? "bopyrid isopod" Moore et al., 2003: 368 [Bear Seamount, $39^{\circ} 55^{\prime} \mathrm{N}, 67^{\circ} 30^{\prime} \mathrm{W}$; probably infesting G. sculpta (as that is the only Glyphocrangon listed)]; Ahyong, 2006: 68 

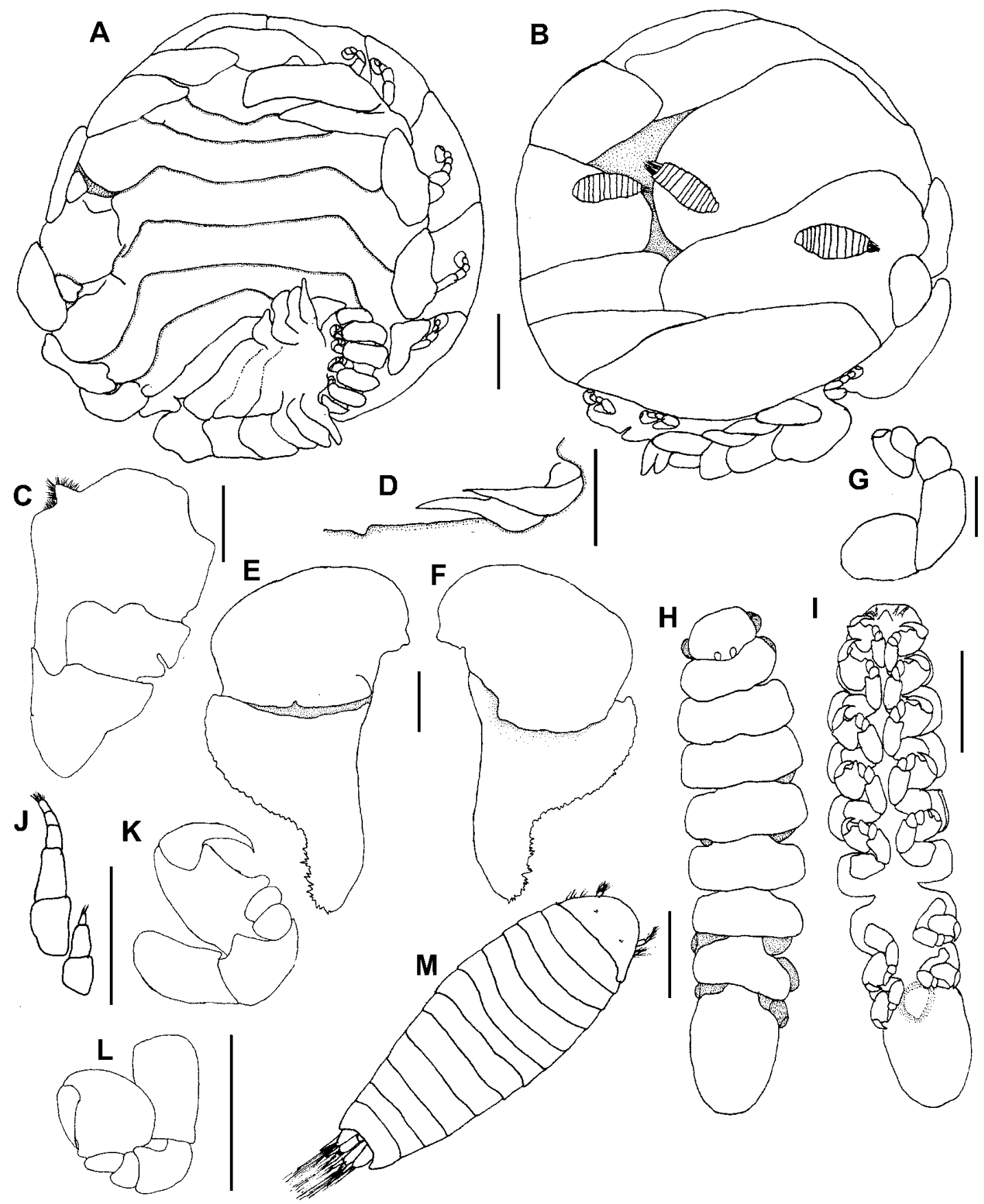

Fig. 6. Bathygyge grandis Hansen, 1897, female (CIEGL002801) (A-G): A. Dorsal view. B. Ventral view. C. Left maxilliped, external view. D. Left side of barbula. E. Left oostegite 1, external view. F. Left oostegite 1, internal view. G. Right pereopod 1. Male (CIEGL002801) (H-M): H. Dorsal view. I. Ventral view. J. Antennae and antennule. K. Pereopod 1. L. Pereopod 7. Scale: $2 \mathrm{~mm}$ (A, B); $1 \mathrm{~mm}$ (D-I); $0.5 \mathrm{~mm}$ $(\mathrm{C}, \mathrm{K}-\mathrm{M}) ; 0.25 \mathrm{~mm}(\mathrm{~J})$. 
[Norfolk Ridge, Tasman Sea, infesting Glyphocrangon dimorpha Komai, 2004].

"bopyrid isopod" Han and Li, 2007: 550 [East China Sea, infesting Glyphocrangon megalophthalma de Man, 1918, material examined herein].

Material ExAmined: Infesting Glyphocrangon megalophthalma de Man, 1918, 19, 1ðぇ, 3 cryptoniscus larvae (CIEGL002801), East China Sea, Stn. $28,126^{\circ} 00^{\prime} \mathrm{E}, 26^{\circ} 10^{\prime} \mathrm{N}$, 2000-2150 m, 10 June 1978.

Description: Female: Length $12.19 \mathrm{~mm}$, maximal width across pereomere $3,11.74$ $\mathrm{mm}$, head length $2.38 \mathrm{~mm}$, head width 3.74 $\mathrm{mm}$, pereon length $6.33 \mathrm{~mm}$, distorted approximately $66^{\circ}$ (fig. 6A, B).

Body ovate, all pereomeres distinct. Head ovate, frontal lamina well developed, extended, and covering anterior part of head (fig. 6A). Eyes and antennae indistinct. Maxilliped (fig. 6C) with triangular palp, fringed with thick setae. Plectron long and sharp. Barbula (fig. 6D) with two pairs of long falcate lateral projections on each side and one small tubercle near median.

Coxal plates of pereon very long, those of first two pereomeres covering head. Rounded dorsolateral bosses on first four pereomeres. Tergal projections of pereomeres 2-4 distinct (fig. 6A). Brood pouch closed (fig. 6B). Oostegite 1 with two articles, first article rounded with smooth internal ridge, second article with posterolateral point, posterior edge with setae (fig. 6E, F). Pereopods larger posteriorly, subequal in shape (fig. $6 \mathrm{H}$ ). Pleon short, fused in median portion and abruptly distorted. Pleon of five pleomeres, first four pleomeres with smooth biramous pleopods. Fifth pleomere with uniramous uropods.

Male: Length $5.91 \mathrm{~mm}$, maximal width, across pereomere $4,1.81 \mathrm{~mm}$, head width $1.00 \mathrm{~mm}$, head length $0.47 \mathrm{~mm}$, pereonal length $3.80 \mathrm{~mm}$. Head elliptical, seperated from first pereomere (fig. 6H). Round yellow eyes near posterior edge of head (fig. $6 \mathrm{H}$ ). Antennule of 3 articles, antenna of five articles, all terminally setose (fig. 6J). Pereon segments distinct (fig. 6H), subequal in width. Pereopods subequal in size. Dactyli of first four pereomeres much larger than others (fig. 6K, L). Carpi of last two peropods long, other pereopods with rounded carpi (fig. 6I, $\mathrm{K}, \mathrm{L})$. First four pereopods larger than last three, dactyli of first two larger than others (fig. 6L). Pleon fused into single piece, one proximal tubercle on medioventral surface of pleon; pleopods and uropods lacking (fig. 6I).

Hosts and Localities: Infesting Glyphocrangon longirostris (Smith, 1882), G. megalophthalma de Man, 1918, G. sculpta (Smith, 1882), G. spinulosa (Faxon, 1893) (Crangonidae), off Nayarit, Mexico, Virginia, Middle Atlantic Bight, South Africa, East China Sea. Possibly also on $G$. dimorpha Komai, 2004, G. faxoni de Man, 1918, G. pugnax de Man, 1918, and G. vicaria Faxon, 1896, from Tasman Sea, Indonesia, Philippines and California.

Remarks: This species is in need of reexamination, as is it unclear whether it is or is not a single species with a circumglobal distribution. Unfortunately, the type female was severely damaged even before it was described and no additional eastern Pacific specimens have been collected. Markham (1985a) deferred to Adkison (cited in Markham, 1985a), who indicated he was going to redescribe the species and discuss its systematic position, but that study was never published. Markham (1985a) thought this species was closest to Pseudione affinis (G. O. Sars, 1883), and that it probably should be reassigned to its own subfamily. The present female has three cryptoniscus larvae (fig. 6M) attached to the surface of the oostegites.

\section{Bopyrella Bonnier, 1900}

Diagnosis: Female: Body outline elliptical, asymmetrical. Head fused completely or at least medially with first pereomere. Maxilliped with setose palp. Coxal plates very reduced; dorsolateral bosses usually on first four pereomeres. Barbula with two pairs of projections on each side. Brood pouch widely open. All pereomeres fused, segments indicated laterally or dorsally. Four or five biramous flaplike pleopods. Uropods absent.

Male: Head and first pereomere usually fused, juncture indicated by lateral indentations. Pleon much wider than pereon, 
especially first pleomere. Pleopods and uropods lacking.

Type Species: Bopyrella thomsoni Bonnier, 1900 , by original designation.

OTHER SPeCies: Bopyrella articulata, n. sp., B. calmani (Richardson, 1905), B. harmopleon Bowman, 1956, B. malensis Bourdon, 1980a, B. moluccensis Bourdon, 1983, B. tanytelson Markham, 1985.

REMARKs: Bonnier (1900) erected this genus for Bopyrella thomsoni infesting Alpheus strenuus Dana, 1852, from "îles des Amis" (= Tonga). Besides the type species, Bonnier (1900) questionably included three other species in Bopyrella: Bopyrus palaemonis Risso, 1816 (nomen dubium), Bopyrina nitescens Giard and Bonnier, 1890 (nomen nudum), and Bopyrus alphei Giard and Bonnier, 1890 (nomen nudum; = Bopyrus alphei Richardson, $1900=$ Capitetragonia alphei (Richardson, 1900), n. comb., herein). Bourdon (1980a) reviewed Bopyrella and divided it into three groups according to the degree of fusion of the female pleon. Markham (1985a) concluded that the degree of fusion of the female pleon was important at the generic level and transferred 30 species in Bopyrella to other genera (e.g., Probopyria [= Capitetragonia], Parabopyrella, Probopyrinella, and Synsynella). He retained only five species in Bopyrella, all parasitizing alpheid hosts: B. thomsoni, B. malensis Bourdon, 1980a, from the Maldives, $B$. macginitiei Shiino, 1964, from California, B. harmopleon Bowman, 1956, from Venezuela, and B. calmani (Richardson, 1905), from California. Sassaman et al. (1984) regarded B. macginitiei as a synonym of $B$. calmani. Bourdon (1983) described $B$. moluccensis as a new species from the Moluccas and Markham (1985b) described B. tanytelson from Thailand. Therefore, the genus Bopyrella currently includes six well-described species (Boyko, 2014) plus the poorly known B. palaemonis. An eighth species is described herein.

\section{Bopyrella articulata, n. sp.} Figure 7

Bopyrella glabra An, 2006: 72-73, fig. 31 (unavailable name).
Material Examined: Infesting Alpheus hoplocheles Coutière, 1897. Holotype o (CIEAL570603), allotype ơ (CIEAL570604), Dazhou Island, Hainan Province, $111^{\circ} 20^{\prime} \mathrm{E}$, $18^{\circ} 40^{\prime} \mathrm{N}, 11$ June 1957. Paratypes: 1 ㅇ (CIEAL570605), 1 ơ (CIEAL570606), Dazhou Island, Hainan Province, $111^{\circ} 20^{\prime} \mathrm{E}$, $18^{\circ} 40^{\prime} \mathrm{N}, 11$ June 1957.

Description: Holotype female (CIEAL57 0603): Length $11.24 \mathrm{~mm}$, maximal width $7.06 \mathrm{~mm}$, head length $2.57 \mathrm{~mm}$, head width $2.8 \mathrm{~mm}$, dextral $29^{\circ}$ (fig. 7A, B).

Head subquadrate, fused with pereomere 1 medially, but lateral boundary visible. Frontal lamina lacking, small eyes in lateral corners (fig. 7A). Antennule of three articles, basal article much larger than second article, terminal article with setae. Antenna of four articles, nonsetose (fig. 7C). Maxilliped with large three-segmented palp (fig. 7D), palp and adjacent margin with setae (fig. 7E). Barbula with two pairs of falcate lateral projections on each side (fig. 7F).

Pereon segments distinct, broadest across third pereomere (fig. 7A). First four pereomeres with coxal plates and dorsolateral bosses slightly larger on longer side (fig. 7A). Brood pouch completely open, oostegite 1 visible in ventral view (fig. 7B). Oostegite 1 (fig. $7 \mathrm{G}, \mathrm{H}$ ) with irregular anterior margin, internal ridge bearing many small projections, posterolateral point blunt laterally, curved on posterior edge. Pereopods subequal in size and structure (fig. $7 \mathrm{H}$ ), dactyli blunt. Pleon lateral margin completely fused, but four obscure segments radiate around median of fused pleon. Pleon with five flaplike biramous pleopods, endopodite of pleopod 1 much longer than others (fig. 7B); uropods lacking (fig. 7B).

Description: Allotype male (CIEAL570 604): Length $3.25 \mathrm{~mm}$, maximal width (across pleon 1) $1.49 \mathrm{~mm}$, head width $0.75 \mathrm{~mm}$, head length $0.42 \mathrm{~mm}$. All pereon segments distinct, pleon fused medially (fig. 7I, J). Head ovate with curved posterior edge (fig. 7I). Eyes mediolateral (fig. 7I). Antennae and antennules of three articles each, not visibly setose (fig. 7K). Pereomeres almost equal in width, each with small midventral projection (fig. 7J). All pereopods with six articles, dactyli of first three pereopods much larger than others (fig. $7 \mathrm{~J}$, L). Pleon of six segments, dorsomedian region weakly fused, but distinct in ventral view. 

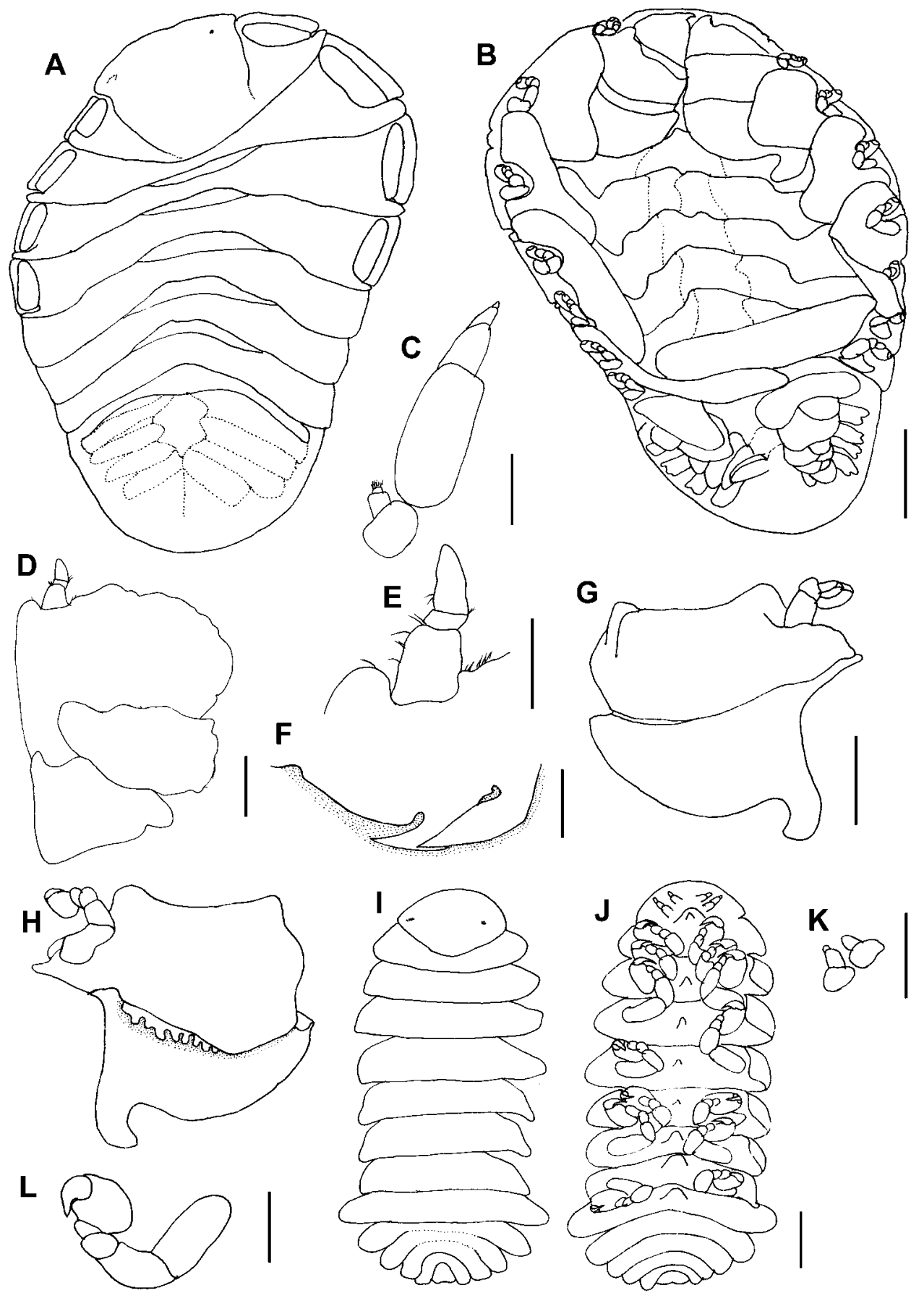

Fig. 7. Bopyrella articulata n. sp., holotype female (CIEAL570603) (A-H): A. Dorsal view. B. Ventral view. C. Left antenna and antennule. D. Left maxilliped, external view. E. Palp of maxilliped. F. Left side of barbula. G. Left oostegite 1, external view. H. Left oostegite 1, internal view. Allotype male (CIEAL570604) (I-L): I. Dorsal view. J. Ventral view. K. Right antenna and antennule. L. Left pereopod 4. Scale: $2 \mathrm{~mm}$ (A, B); $1 \mathrm{~mm}(\mathrm{G}, \mathrm{H}) ; 0.5 \mathrm{~mm}(\mathrm{D}-\mathrm{F}, \mathrm{I}, \mathrm{J}) ; 0.25 \mathrm{~mm}(\mathrm{C}, \mathrm{K}, \mathrm{L})$. 
Pleomere 1 widest, with midventral tubercle; pleopods and uropods lacking (fig. 7J).

VARIATION: Paratype female (CIEAL 570605) immature, total length $7.14 \mathrm{~mm}$, widest pereomere $4.68 \mathrm{~mm}$, almost symmetrical. Paratype male (CIEAL570606) mature, similar to allotype.

ETymology: The specific name, articulata, refers to the maxilliped of the female with its three-segmented palp.

Host AND Locality: Infesting Alpheus hoplocheles Coutière, 1897 (Alpheidae), Hainan Province, China.

Remarks: Bopyrella articulata has the female head fused with the first pereomere, a triarticulated maxilliped palp, a fused pleon, and four pairs of biramous pleopods. The first pleomere of the male is much wider than the other pereomeres and pleomeres. The new species is most related to $B$. thomsoni, which has both a similar (complete) fusion of the female pleomeres as well as a similar male pleon shape, but (1) the maxilliped of the new species has a triarticulated palp (B. thomsoni female with nonarticulated palp) and (2) male of $B$. articulata with midventral tubercles on all pereomeres and pleomere 1 (lacking in B. thomsoni). The new species and B. thomsoni are distinguished from the other five species of Bopyrella by having the pleon completely fused, without any lateral indentations indicating segmentation on either side.

\section{Bopyrella tanytelson Markham, 1982}

Bopyrella tanytelson Markham, 1985b: 20-23, fig. 10, table 1 [Thailand, infesting Alpheus sp.]; Markham, 1990: 559-560 (Hong Kong, infesting Synalpheus streptodactylus Coutière, 1905); Markham, 1992a: 298, table 1; Kensley, 2001: 223; Li, 2003: 139, 154, 157; Liu, 2008: 691.

Material Examined: None.

Hosts AND LocAlities: Infesting Synalpheus streptodactylus Coutière, 1905, Alpheus sp. (Alpheidae), Hong Kong, Thailand.

Remarks: As noted by Markham, the mentions by Miya (1972) and Monod (1976) of bopyrids on Synalpheus streptodactylus from Japan and New Caledonia, respectively, could be Bopyrella tanytelson, but no specimens from these collections have ever been critically examined.

\section{KEY TO THE SEVEN SPECIES OF BOPYRELLA BONNIER, 1900, BASED ON FEMALES}

1a. Four pairs of pleopods $\ldots \ldots \ldots \ldots 2$

1b. Five pairs of pleopods ........... 3

2a. Pereomeres distinct, median part of pleon fused, but pleomeres indicated by lateral indentations .. B. moluccensis Bourdon, 1983

2b. Pereon fused medially, pleon fused but with lateral indentations on long side . . . . B. malensis Bourdon, 1980a

3a. Pleon completely fused, without lateral indentations .............4 4

3b. Pleon incompletely fused, lateral indentations on at least one side ........ 5

4a. Maxilliped with nonarticulated palp..... . . . . . . . B. thomsoni Bonnier, 1900

4b. Maxilliped with triarticulated palp ...... ............ B. articulata, n. sp.

5a. Maxilliped palp articulated ......... ........ B. harmopleon Bowman, 1956

5b. Maxilliped palp nonarticulated ...... 6

6a. Pleomeres 1-4 distinct, last two pleomeres fused ...... B. calmani (Richardson, 1905)

6b. Pleomeres indistinct, indicated only by lateral indentations on long side. . . . . . . .

B. tanytelson Markham, 1985

\section{Bopyrinella Nierstrasz and Brender à Brandis, 1925}

Diagnosis: Female Body long and moderately distorted. Head fused with first pereomere at least medially. Maxilliped without palp, or with setose palp. Narrow coxal plates and obscure dorsolateral bosses on long side. Five or seven pairs of oostegites, only oostegite 1 well developed, right and left oostegites not symmetrical, other oostegites reduced. Pleon of six segments laterally distinct but fused dorsally and sometimes ventrally. Five pairs of flaplike uniramous pleopods. Uropods absent.

Male: Body much longer than wide. Head fused with first pereomere on posterior margin. Pereomeres distinct on dorsal and lateral sides, midventral tubercles lacking. Pleon of six segments, fused at least on ventral surface. Pleopods reduced, no uropods. 
TyPe Species: Bopyrinella antillensis Nierstrasz and Brender à Brandis, 1925 (= Bopyrina thorii Richardson, 1904), by monotypy.

Other Species: Bopyrinella albida Shiino, 1958, B. nipponica Shiino, 1936, B. parameces, n. sp., B. stricticauda Monod, 1933.

REMARKs: Nierstrasz and Brender à Brandis (1925) erected Bopyrinella with the type species B. antillensis parasitizing Thor floridanus Kingsley, 1878, from Curaçao. Markham (1985a) regarded $B$. antillensis as a junior synonym of Bopyrina thorii Richardson, 1904, known from the same host in Florida; he then removed $B$. thorii from Bopyrina, making the correct name for the type species Bopyrinella thorii. Monod (1933) described "Bopyrinella (?) stricticauda" from an unidentified alpheid in the Gulf of Suez, but while Markham (1985a) thought it did not belong to Bopyrinella, he did not specify what characters indicated that it was not in the correct genus nor did he state where it should be placed. Based on the description and illustrations of Monod (1933), the species may be correctly placed in Bopyrinella, but some characters (particularly those of the mouthparts) are not well described. Shiino (1936) described Bopyrinella antilensis var. nipponica infesting Spirontocaris rectirostris $(=$ Heptacarpus rectirostris (Stimpson, 1860)) from Japan and Markham (1985a) raised it to a full species as B. nipponica. Shiino (1958) described $B$. albida infesting Athanas kominatoensis Kubo, 1942 (= Arete indicus Coutière, 1903), from Japan. Therefore, there are currently four species in Bopyrinella, two on hosts in Hippolytidae and two from hosts in Alpheidae. A new species from a new host species and family, Ogyrididae, is described herein.

\section{Bopyrinella albida Shiino, 1958}

Bopyrinella albida Shiino, 1958: 62-64, fig. 17 [Japan, infesting Arete indicus Coutière, 1903]; Bourdon, 1968: 170; Shiino, 1972: 8; Markham, 1985a: 81; Markham, 1985b: 3, 25-28, 62, fig. 12, table 1 [Thailand, infesting Athanas dimorphus Ortmann, 1894]; Markham, 1990: 559 [Hong Kong, infesting Arete dorsalis Stimpson, 1860]; Bruce, 1990: 585; Nakashima, 1995: 12, table 3 [Japan, infesting A. indicus]; Kensley, 2001: 223; Li, 2003: 139, 154, 157; Liu, 2008: 691.

\section{Material Examined: None.}

Hosts and Localities: Infesting Arete indicus Coutière, 1903, Athanas dimorphus Ortmann, 1894, Arete dorsalis Stimpson, 1860 (Alpheidae), Japan, Thailand, Hong Kong.

REMARKs: The type host was originally cited as Athanas kominatoensis Kubo, 1942, which is treated as a doubtful synonym of Arete indicus by De Grave and Fransen (2011). Bopyrinella albida is one of only three species of bopyrines known to possess seven pairs of oostegites.

\section{Bopyrinella parameces, $\mathrm{n}$. $\mathrm{sp}$.} Figure 8

Bopyrinella paramecia An, 2006: 76-77, fig. 33 (unavailable name).

Material Examined: Infesting Ogyrides orientalis (Stimpson, 1860). Holotype 우 (CIEOG501201), allotype ơ (CIEOG501202), Huiquan Bay, Qingdao, Shandong Province, $120^{\circ} 20^{\prime} \mathrm{E}, 36^{\circ} 00^{\prime} \mathrm{N}, 10$ December 1950.

DesCription: Holotype female (CIEOG 501201): Length $5.66 \mathrm{~mm}$, maximal width $2.41 \mathrm{~mm}$, head length $0.67 \mathrm{~mm}$, head width $0.69 \mathrm{~mm}$, pereon length $2.15 \mathrm{~mm}$, pleon length $2.88 \mathrm{~mm}$ (fig. $8 \mathrm{~A}, \mathrm{~B}$ ).

Body width about $1 / 3$ length, pereon length subequal to pleon length, flattened, calceiform, slightly distorted. Head oval, without frontal lamina, fused with first pereomere medially, eyes lacking (fig. 8A). Antennule reduced to single article, antenna lacking (fig. 8B). Maxilliped without palp (fig. 8C), spur blunt and short. Barbula (fig. 8D) with two pairs of smooth projections on each side, flattened near center.

Pereomeres distinct, broadest across third and fourth pereomeres (fig. 8A). Narrow coxal plates on left side of all pereomeres, right side only on first pereomere. Dorsolateral bosses on first four pereomeres of left side, and only first pereomere of right side. Brood pouch widely open (fig. 8B), oostegite 1 almost symmetrical except for posterolateral point (fig. 8B, E, F), small and depressed anterior article, large posterior article. Internal ridge smooth, posterolateral point rounded. Other four pairs of oostegites small, triangular (fig. 8B). All pereopods subequal in size and structure (fig. 8G), carpi and meri smooth, 

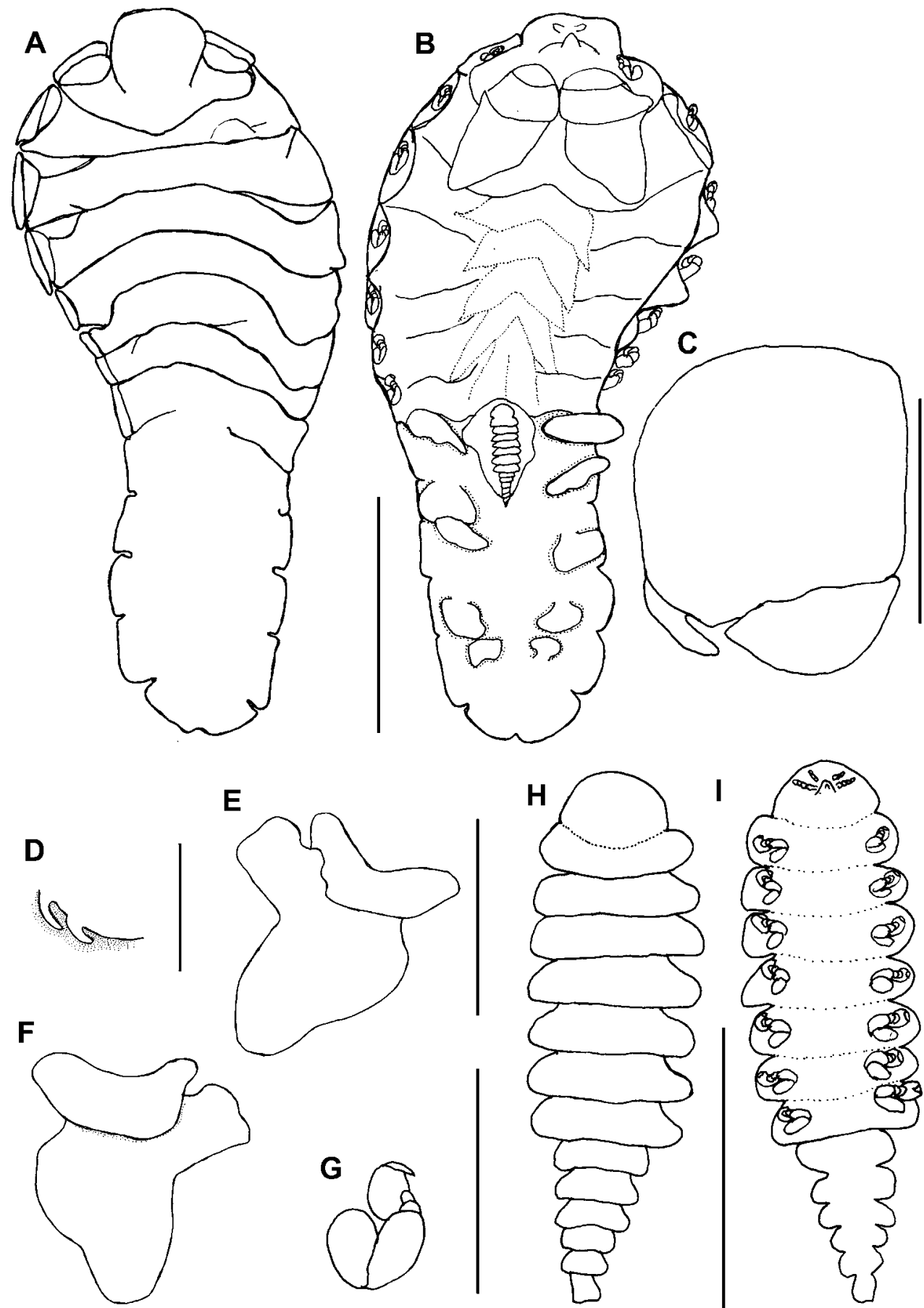

E
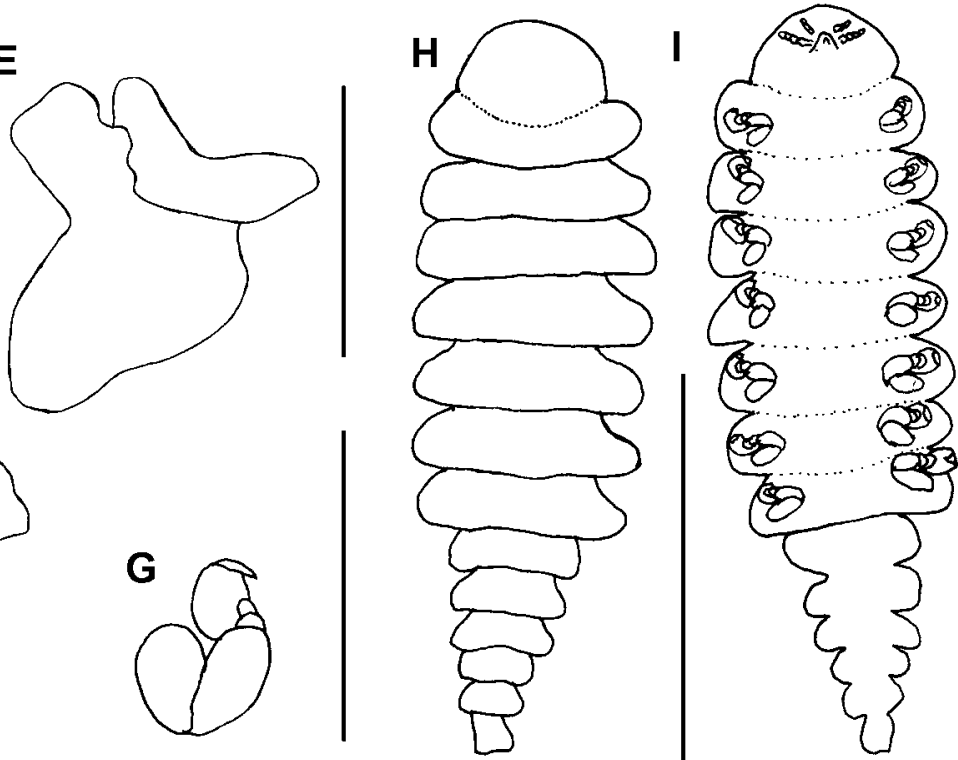

Fig. 8. Bopyrinella parameces n. sp., holotype female (CIEOG501201) (A-G): A. Dorsal view. B. Ventral view. C. Right maxilliped, external view. D. Right side of barbula. E. Right oostegite 1, external view. F. Right oostegite 1, internal view. G. Right pereopod 2. Allotype male (CIEOG501202) (H, I): H. Dorsal view. I. Ventral view. Scale: $2 \mathrm{~mm}$ (A, B); $1 \mathrm{~mm}$ (E, F); $0.5 \mathrm{~mm}(\mathrm{C}, \mathrm{D}, \mathrm{G}-\mathrm{I})$. 
bases of all pereopods stout. Pleon of six pleomeres, elongated, first pleomere identifiable from dorsal suture, other pleomeres detected only from lateral indentations. Five pairs of uniramous flaplike pleopods, posteriorly becoming smaller (fig. 8B). Sixth pleomere indented posteromedially, uropods lacking (fig. 8B).

Description: Allotype male (CIEOG501 202): Length $0.87 \mathrm{~mm}$, maximal width (across pereon 3) $0.29 \mathrm{~mm}$, head width $0.18 \mathrm{~mm}$, head length $0.14 \mathrm{~mm}$. All pereon segments distinct, pleomere distinct in dorsal view (fig. $8 \mathrm{H}, \mathrm{I}$ ). Head elliptical, fused with first pereomere (fig. $8 \mathrm{H}$ ), eyes absent (fig. $8 \mathrm{H}$ ). Antennule of three articles, antenna of four articles, terminally nonsetose (fig. 8I). Pereomeres subequal in width, midventral projections lacking (fig. $8 \mathrm{H})$. All pereopods small, posteriorly becoming slightly larger (fig. 8I). Pleon sharply narrow, pleomeres distinct only on dorsal surface, no pleopods or uropods (fig. 8I).

Eтyмоlogy: The specific name, parameces, refers to the female's long elliptical, calceiform, outline.

Host AND Locality: Infesting Ogyrides orientalis (Stimpson, 1860) (Ogyrididae), Shandong Province, China.

REMARKs: The present specimens agree with three of the other species of Bopyrinella in having (1) female with relatively long body outline, (2) only oostegite 1 well developed and different in shape on left and right sides, (3) brood pouch completely open, (4) five pairs of flaplike uniramous pleopods and lacking uropods. The fourth species, B. albida, has rudimentary sixth and seventh oostegites, a character state that was surprisingly not emphasized by Shiino (1958) or Markham (1985b) as this was the first recorded species in Bopyrinae bearing seven pairs of oostegites. Previously reported hosts of Bopyrinella species are from Hippolytidae and Alpheidae, but the present host is in Ogyrididae. All three families, however, belong to Alpheoidea. The only other bopyrid known to infest a species in Ogyrididae is Ogyridione caroliniana Markham, 1988, which is not at all similar to the new species. Bopyrinella parameces, n. sp., is most related to Bopyrinella albida Shiino, 1958 , but can be distinguished from it by (1) the new species lacks a frontal lamina $(B$. albida with large frontal lamina), (2) the body of the new species is only slightly distorted ( $B$. albida with body highly distorted), (3) the oostegite 1 of the new species differ only slightly from each other in shape $(B$. albida with very different oostegite 1), (4) the new species has only five pairs of oostegites (B. albida with seven pairs), (5) the new species with only one pair of antennae (antennule) (B. albida with antennule and antennae), (6) male of the new species without pleopods (B. albida with tubercular pleopods), and (7) the new species lacks eyes (B. albida with eye spots).

\section{KEY TO FOUR SPECIES OF BOPYRINELLA NIERSTRASZ AND BRENDER À BRANDIS, 1925, BASED ON FEMALES (BOPYRINELLA STRICTICAUDA MONOD, 1933, NOT INCLUDED IN KEY)}

1a. Four pairs of pleopods ......... B. thorii (Richardson, 1904)

1b. Five pairs of pleopods .......... 2

2a. Maxilliped with setose palp ......... B. nipponica Shiino, 1936

2b. Maxilliped without palp ......... 3

3a. Head with frontal lamina, seven pairs of oostegites ....... B. albida Shiino, 1958

3b. Head without frontal lamina, five pairs of oostegites ....... B. parameces, n. sp.

Bopyrione Bourdon and Markham, 1980

Diagnosis: Female: Body outline ovate, slightly distorted. Head separated from first pereomere, but deeply embedded into pereon. Maxilliped without palp. Barbula with two pairs of falcate lateral projections on each side. Brood pouch medially open or closed, oostegite 1 with long posterolateral point and smooth internal ridge. Pleon of five or six obscure pleomeres, lateral margins almost entire. Four or five pairs of uniramous flaplike pleopods, lateral plates and uropods lacking.

Male: Body longer than wide, pereomeres distinct, pleomeres fused. Most or all pereomeres with midventral tubercles, pleopods and uropods lacking.

Type SPecies: Bopyrione synalphei Bourdon and Markham, 1980, by original designation. 
Other SPeCies: Bopyrione longicapitata Markham, 1982, B. multifeminae, n. sp., B. toloensis Markham, 1982, B. woodmasoni (Chopra, 1923).

Remarks: Bourdon and Markham (1980) erected Bopyrione for B. synalphei infesting Synalpheus goodei Coutière, 1909, S. bousfieldi Chace, 1972, and $S$. pectiniger Coutière, 1907, plus three other unidentified Synalpheus sp. (sp. near $S$. goodei, sp. near $S$. longicarpus (Herrick, 1891) and Synalpheus sp.) from the western Atlantic Ocean (Gulf of Mexico off Florida, Haiti, and Curaçao). Bopyroides woodmasoni Chopra, 1923, infesting Synalpheus sp. from India, was transferred to Bopyrione by Bourdon and Markham (1980). Markham (1982) later described two new species from Hong Kong: B. longicapitata, infesting an Alpheus sp. questionably identified as Alpheus lobidens De Haan, 1849, and $B$. toloensis infesting an Alpheus sp. questionably identified as Alpheus microstylus (Bate, 1888). All hosts of the four previously known Bopyrione species are in Alpheidae.

\section{Bopyrione longicapitata Markham, 1982}

Bopyrione longicapitata Markham, 1982: 348351, figs. 14, 15 [Hong Kong, infesting Alpheus lobidens? De Haan, 1849]; Markham, 1985a: 59; Markham, 1992a: 285 [Hong Kong, infesting Alpheus bisincisus De Haan, 1849]; Li, 2003: 140, 157; Liu, 2008: 691 .

Material Examined: None.

Hosts AND Localities: Infesting Alpheus lobidens? De Haan, 1849, and Alpheus bisincisus De Haan, 1849 (Alpheidae), Hong Kong.

REMARKs: The type host was only provisionally identified as $A$. lobidens in Markham (1982).

Bopyrione multifeminae, $\mathrm{n}$. sp. Figures 9, 10

Bopyrione multifemina An, 2006: 87-88, fig. 41, pl. 5 (unavailable name).

Material Examined: Infesting Alpheus sp., holotype $ᄋ$ (CIEAL991101), allotype ơ (CIEAL991103), Jiaozhou Bay, Stn. 1, $120^{\circ} 21^{\prime} \mathrm{E}, 36^{\circ} 10^{\prime} \mathrm{N}, 6 \mathrm{~m}, 10$ November 1999 , coll. Zhang. Paratypes: 1 ㅇ (CIEAL991102), same locality and same branchial chamber as holotype; 3우, host infested in both branchial chambers (CIEAL981101), 1 đ (CIEAL98 1102), Jiaozhou Bay, Stn. 8, $120^{\circ} 14^{\prime} \mathrm{E}$, $36^{\circ} 02^{\prime} \mathrm{N}, 20 \mathrm{~m}, 6$ November 1998, coll. Zhang; 2 우, 1 ot host infested in both branchial chambers (CIEAL111941), southern Yellow Sea, Stn. $11194,120^{\circ} 30^{\prime} \mathrm{E}, 34^{\circ} 30^{\prime} \mathrm{N}$, 17 m, 14 June 2004, coll. Hongfa Wang; 1 \%, 1 o from right branchial chamber (CIEAL 111942), southern Yellow Sea, Stn. 11194, $120^{\circ} 30^{\prime} \mathrm{E}, 34^{\circ} 30^{\prime} \mathrm{N}, 17 \mathrm{~m}, 14$ June 2004, coll. Hongfa Wang.

DESCRIPTION: Holotype female (CIEAL 991101): Length $5.01 \mathrm{~mm}$, maximal width $3.12 \mathrm{~mm}$, head length $1.56 \mathrm{~mm}$, head width $1.38 \mathrm{~mm}$ (fig. 9A, B).

Head triangular, posteriorly acute, distinctly separated from first pereomere. Frontal lamina and eyes lacking (fig. 9A). Antennule of three articles, antenna of four articles, both nonsetose (fig. 9C). Maxilliped triangular, without palp, spur sharp (fig. 9D). Barbula with two pairs of acute falcate lateral projections on each side, smooth near median (fig. 9E).

Pereon broadest across third pereomere (fig. 9A). All pereomeres without coxal plates or dorsolateral bosses. Brood pouch partly open (fig. 9B). Oostegite 1 (fig. 9F, G) without median groove, internal ridge smooth. First article of oostegite 1 much wider than second article. Posterolateral point curved posteriorly. Pereopods subequal in size and shape (fig. 9H), bases of all pereopods produced into small lobes. Pleon of six pleomeres, margins entire, first five bearing flaplike uniramous pleopods, posteriorly smaller, margins undulating (fig. 9B, I). Uropods lacking (fig. 9B).

Description: Allotype male (CIEAL9911 03): Length $1.02 \mathrm{~mm}$, maximal width (across pereon 1) $0.40 \mathrm{~mm}$, head width $0.32 \mathrm{~mm}$, pleonal length $0.24 \mathrm{~mm}$. All dorsal surfaces setose (fig. 10A), pereon segments distinct, pleon fused into single piece (fig. 9J, 10A). Head elliptical, posterior edge curved (fig. 9J); black eye pigment present on posterolateral corners (fig. 9J). One pair of antennae (? antennules) of three articles, setose (fig. 10B). Pereomeres almost subequal in width, first pereomere widest (fig. 9J), midventral 

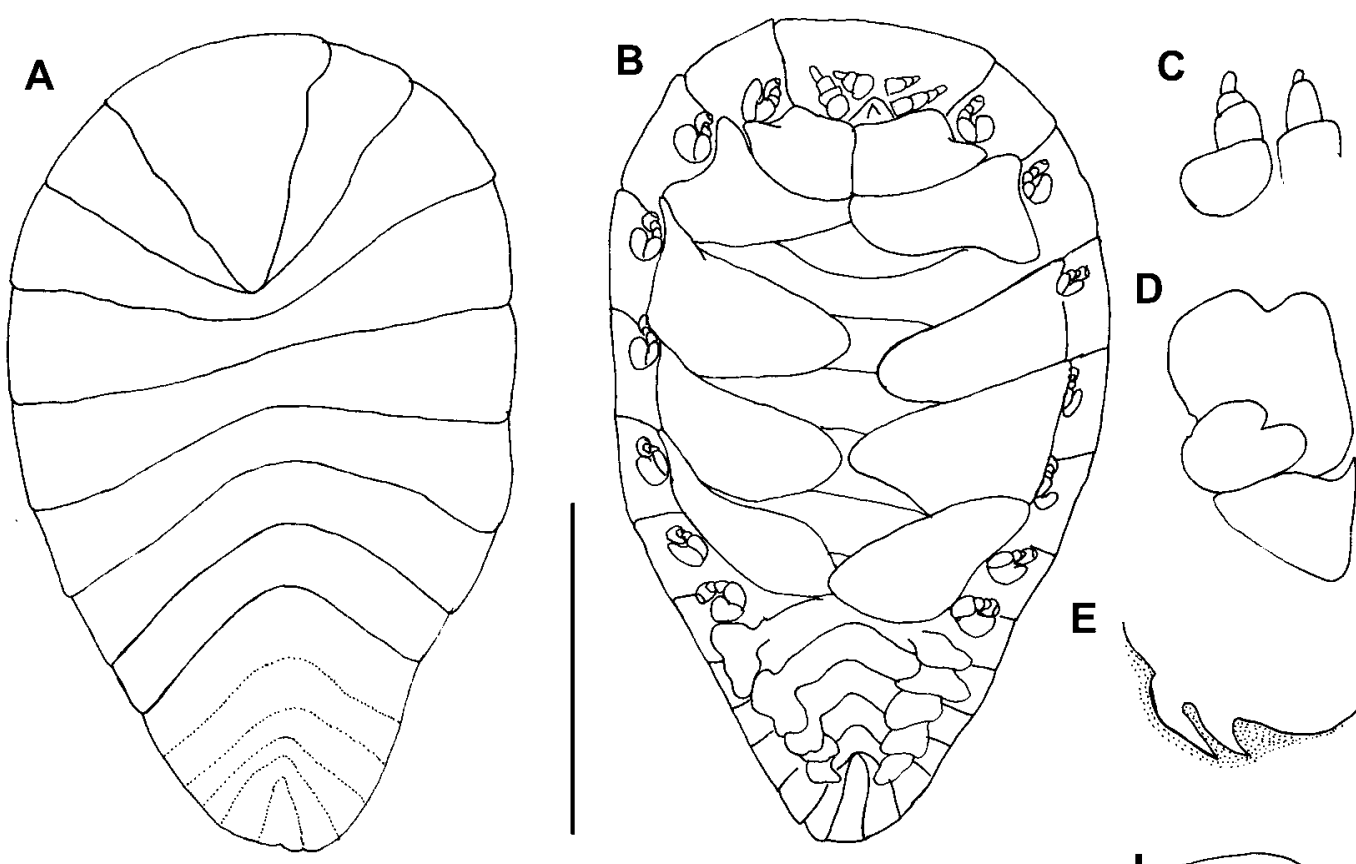

D
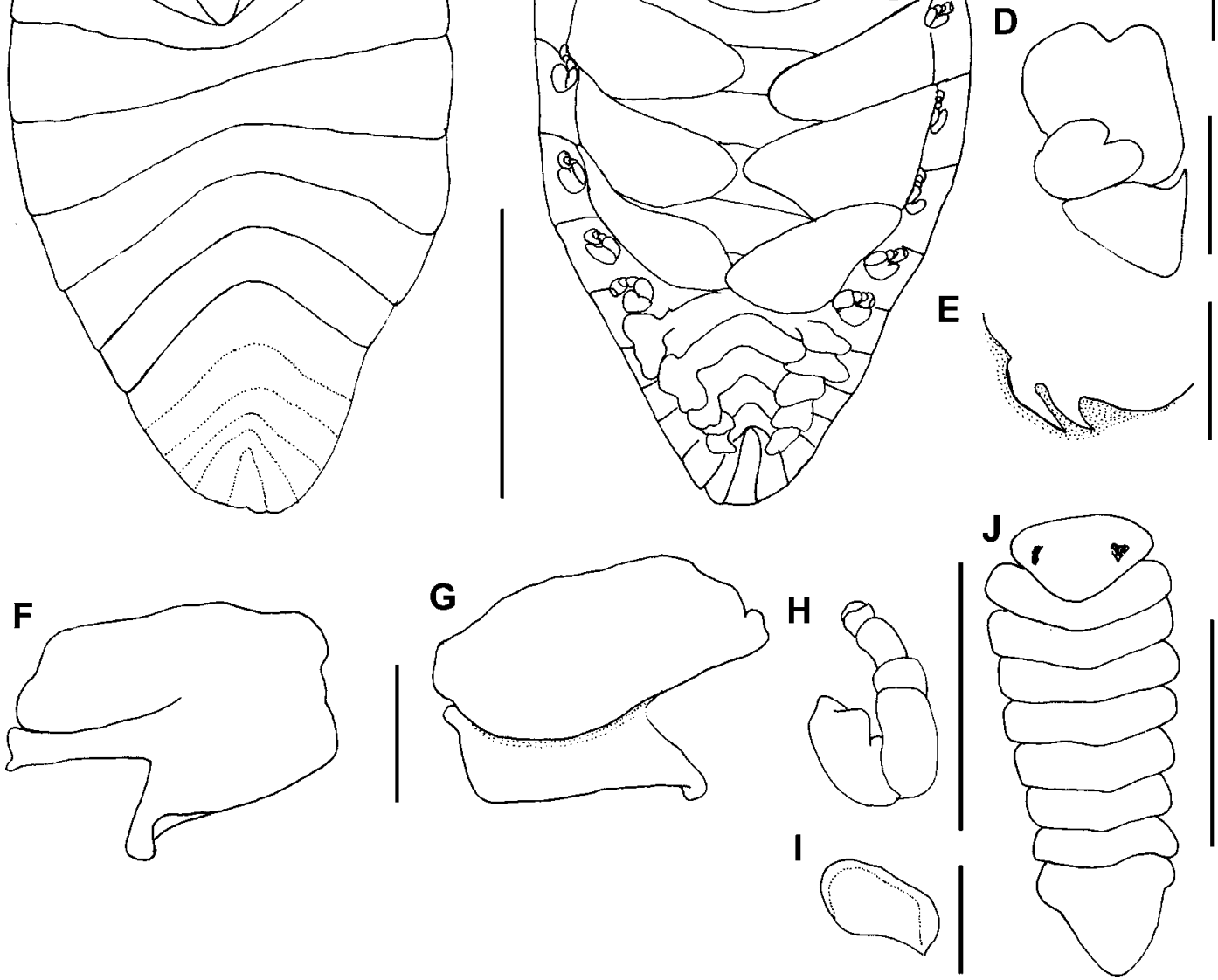

Fig. 9. Bopyrione multifeminae n. sp., holotype female (CIEAL991101) (A-I): A. Dorsal view. B. Ventral view. C. Right antenna and antennule. D. Right maxilliped, external view. E. Right side of barbula. F. Right oostegite 1, external view. G. Right oostegite 1, internal view. H. Right pereopod 2. I. Right pleopod 3. Allotype male (CIEAL991103) (J): J. Dorsal view. Scale: $1 \mathrm{~mm}$ (A, B); $0.25 \mathrm{~mm}$ (C-J).

projections (fig. 10B) lacking. All pereopods with platelike scales on ventral surface (fig. 10C), first three pereopods largest, all carpi and meri nearly fused (fig. 10D, E). Pleon fused into single piece, only first pleomeres visible with dorsal indentations, others completely fused; pleopods and uropods lacking (fig. 9J).

VARIATION: All paratype females agree with the holotype except one immature female
(CIEAL111941) that has a proportionally longer body and the brood pouch completely closed.

Eтymology: The specific name, multifeminae, refers to the occupation of the same branchial chamber of the host by two females.

Host(s) and Localities: Infesting Alpheus sp. (likely more than one species) (Alpheidae), Shandong Province and southern Yellow Sea, China, 6-20 m. 


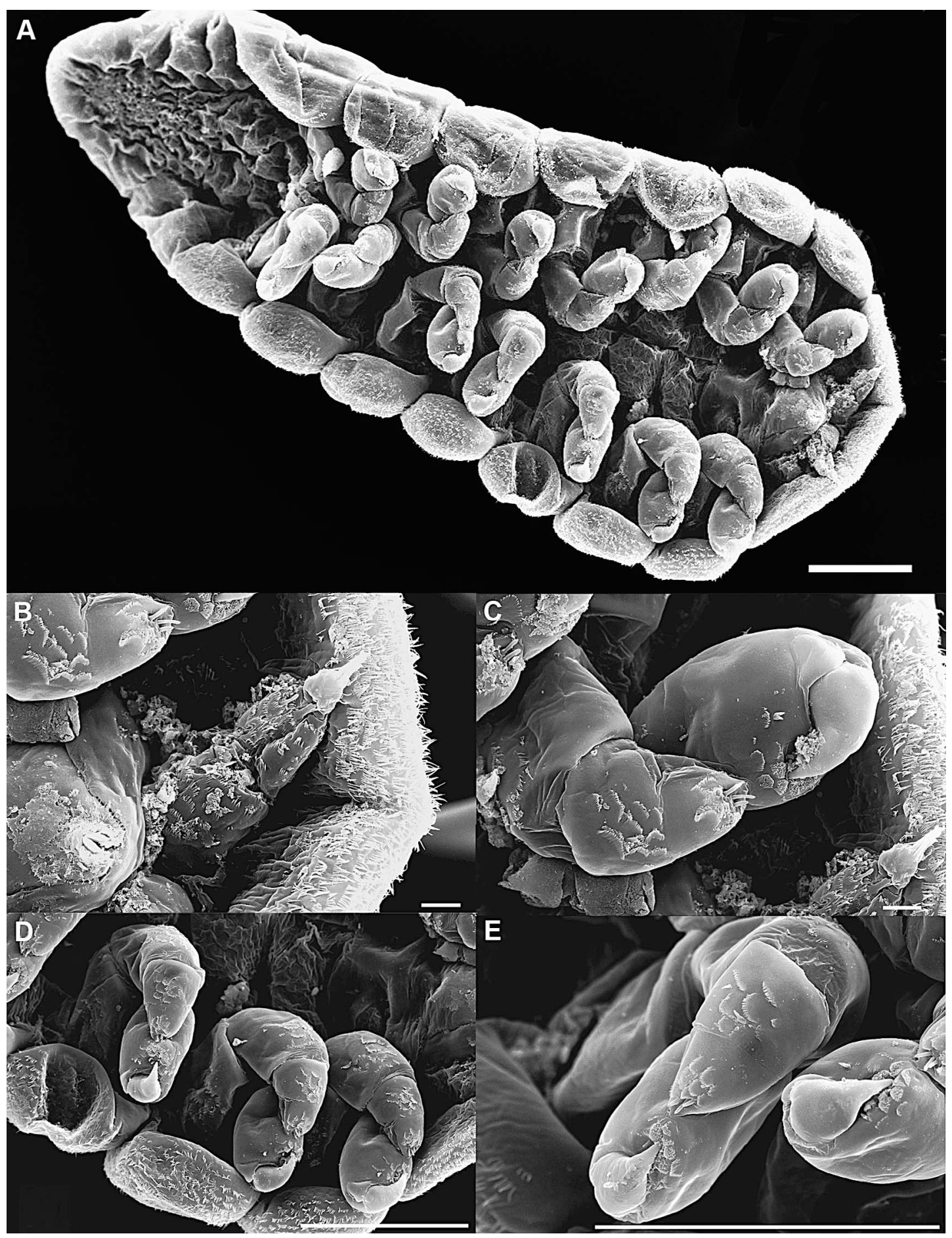

Fig. 10. Bopyrione multifeminae n. sp. SEM image of male (CIEAL981102) (A-E): A. Ventral view of the male. B. Right antenna and antennule. C. Right pereopod 1. D. Left pereopods 1-3. E. Left pereopod 5. Scale: $100 \mu \mathrm{m}(\mathrm{A}, \mathrm{D}, \mathrm{E}) ; 10 \mu \mathrm{m}(\mathrm{B}, \mathrm{C})$. 
Remarks: Bopyrione multifeminae, n. sp., shares with the other four species in Bopyrione: female with head deeply embedded into the pereon, maxilliped without palp, barbula with two pairs of falcate lateral projections on each side, uniramous pleopods; lateral plates and uropods lacking. The new species is most closely related to $B$. longicapitata, but (1) the female of $B$. multifeminae, n. sp., lacks eyes and a frontal lamina (B. longicapitata female with eyes and frontal lamina), (2) B. multifeminae, n. sp., female without any coxal plates or dorsolateral bosses $(B$. longicapitata female with reduced coxal plates), (3) $B$. multifeminae, $\mathrm{n}$. sp., female pleopods small and flaplike, not reaching the median of the pleon (B. longicapitata female with larger flaplike pleopods, extending to the median of the pleon), (4) B. multifeminae, n. sp., male without midventral tubercles ( $B$. longicapitata male with midventral tubercles on all pereomeres). Males with a single pair of antennae occur in both $B$. multifeminae, n. sp., and $B$. toloensis. It is typical for bopyrids to occur with one female and one male in any occupied branchial chamber, occasionally with more than one male accompanying a female, but more than one collection of $B$. multifeminae, n. sp., was made with the unusual condition of two females and one male in the same branchial chamber.

\section{Bopyrione toloensis Markham, 1982}

Bopyrione toloensis Markham, 1982: 351-354, figs. 16-17 [Hong Kong, infesting Alpheus microstylus? (Bate, 1888)]; Markham, 1985a: 59; Morton, 2003: 37; Li, 2003: 140, 157; Liu, 2008: 691.

Material Examined: None.

Hosts AND Localities: Infesting Alpheus microstylus? (Bate, 1888 (Alpheidae)), Hong Kong.

Remarks: The host was only provisionally identified as A. microstylus in Markham (1982).

\section{KEY TO THE FIVE SPECIES OF BOPYRIONE BOURDON AND MARKHAM, 1980}

1a. Head triangular, pleopods large, flaplike . . 2

1b. Head subovate, pleopods small, tubercular 2a. Anterior margin of head entire ....... 3

2b. Anterior margin of head crenulate ..... ........ B. toloensis Markham, 1982

3a. Eyes present, brood pouch closed...... ....... B. longicapitata Markham, 1982

3b. Eyes lacking, brood pouch medially open ........ B. multifeminae, n. sp.

4a. First four pereomeres with dorsolateral bosses . . . . . B. woodmasoni (Chopra, 1923)

4b. All pereomeres without dorsolateral bosses . B. synalphei Bourdon and Markham, 1980

\section{Bopyroides Stimpson, 1864}

Diagnosis: Female: Body subovate, moderately distorted. Head separate from pereon. Distinct frontal lamina, palp, coxal plates, dorsolateral bosses. Posterolateral point of first oostigite not directed backward. Pleopods uniramous or absent, uropods lacking.

Male: Body elongate, without midventral tubercles. Pleon completely fused, without pleopods or uropods.

TYPE SPECIES: Bopyroides acutimarginatus Stimpson, $1864 \quad(=$ Bopyrus hippolytes Kröyer, 1838), by original designation.

OTHER SPecies: Bopyroides cluthae (Scott, 1902), B. shiinoi Rybakov and Avdeev, 1991.

REMARKs: Stimpson (1864) erected this genus for Bopyroides acutimarginatus from Puget Sound. Bourdon (1968) reviewed the genus and considered $B$. acutimarginatus as a synonym of Bopyrus hippolytes, and also synonymized B. furcata Norman, 1905, and Pleurocrypta patiencei Scott, 1902, with $B$. cluthae. Markham (1985a) regarded B. sarsi Bonnier, 1900, as identical with $B$. hippolytes. Rybakov and Avdeev (1991) described B. shiinoi from the northwestern Pacific.

\section{Bopyroides hippolytes (Kröyer, 1838)} Figure 11

Bopyrus hippolytes Kröyer, 1838a: 306-310, 318 , pl. 4, fig. 22 [type locality Greenland; infesting Lebbeus polaris]; Kröyer, 1838b: 78-82, 90, pl. 4, fig. 22.

Bopyroides hippolytes-Markham, 1985a: 5253 (extensive synonymy); Bourdon, 1987: 342; Kim and Kwon, 1988, 212-213, fig. 8 [Korea, infesting Pandalus borealis]; Rybakov, 1990: 409 [Sea of Okhotsk, infesting $P$. borealis, host for Bourdonia tridentata Rybakov, 1990 (Cabiropidae)]; Rybakov 


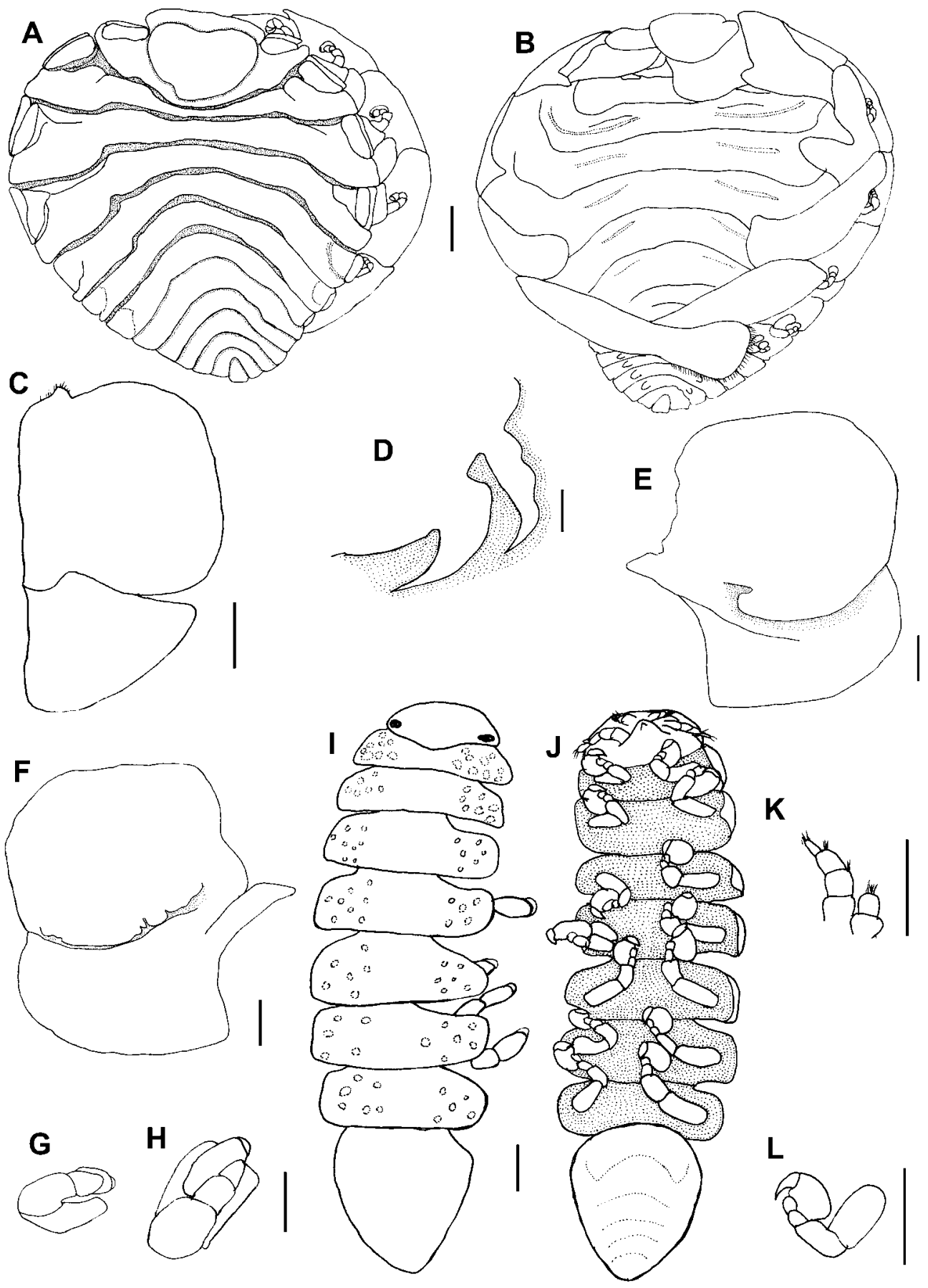

Fig. 11. Bopyroides hippolytes (Kröyer, 1838), reference female (CIEHI401001) (A-H): A. Dorsal view. B. Ventral view. C. Left maxilliped, external view. D. Left side of barbula. E. Left oostegite 1, external view. F. Left oostegite 1, internal view. G. Left pereopod 1. H. Left pereopod 7. Reference male (CIEHI401002) (I-L): I. Dorsal view. J. Ventral view. K. Right antenna and antennule. L. Left pereopod 1. Scale: $1 \mathrm{~mm}$ (A, B); $0.5 \mathrm{~mm}(\mathrm{C}, \mathrm{E}-\mathrm{H},) ; 0.25 \mathrm{~mm}(\mathrm{D}, \mathrm{I}-\mathrm{L})$. 
and Avdeev, 1991: 167-168, fig. 1 [comparison with B. shiinoi]; Saito et al., 2000: 3940 (list); Boyko, 2004: 692-693, fig. 10 [Taiwan, infesting Lebbeus cf. spinirostris (Kobyakova, 1936)]; An, 2006: 78-79, fig. 34 .

Material Examined: Infesting Birulia kishinouyei, 1 ㅇ (CIEHI401001), 1 đ (CIEHI 401002), Yellow Sea, Stn, 4010, $123^{\circ} 30^{\prime} \mathrm{E}$, $33^{\circ} 30^{\prime} \mathrm{N}, 60 \mathrm{~m}, 6$ December 1959, coll. Jieshan $\mathrm{Xu}$ and $\mathrm{Mu}$ Chen.

Description: Female (CIEHI401001): Length $8.38 \mathrm{~mm}$, maximal width $7.30 \mathrm{~mm}$, head length $1.92 \mathrm{~mm}$, head width $2.17 \mathrm{~mm}$, pleon length $2.60 \mathrm{~mm}$, distorted $19^{\circ}$. All body segments distinct (fig. 7A, B). Head oval, frontal lamina extending beyond head, anterior edge shallowly bilobate, posterior edge curved, eyes absent (fig. 7A). Maxilliped (fig. 7C) with short setose palp and obscure spur. Barbula (fig. 7D) with two pairs of long falcate lateral projections on each side, outer one more slender.

Pereon broadest across third pereomere (fig. 11A). Coxal plates rudimentary on both sides. Brood pouch completely open (fig. 11B). Oostegite 1 (fig. 11E, F) with two equally long articles, nearly smooth internal ridge bearing one large and two or three small projections, posterolateral point directed laterally. Pereopods larger posteriorly (fig. 11G, $\mathrm{H}$ ), with blunt and small dactyli. Pleon of six pleomeres, lateral plates lacking. Four pairs of small tubercular uniramous pleopods, uropods lacking.

DescriPtion: Male (CIEHI401002): Length $2.95 \mathrm{~mm}$, maximal width (across pereon 4) $0.83 \mathrm{~mm}$, head width $0.54 \mathrm{~mm}$, pleonal length $0.79 \mathrm{~mm}$. All pereomeres distinctly segmented, pleon fused (fig. 11I, J). Head a flattened ellipse, posterior edge curved (fig. 11I), black eyes in posterolateral corners (fig. 11I). Antennule of two articles, antenna of four articles, terminally setose (fig. 11K). Pereomeres subequal in width, lacking midventral projections (fig. 11J). Pereopods of subequal size and structure (fig. 11L). Pleon completely fused, without pleopods or uropods, obscure segment demarcations visible in ventral view (fig. 11J).

Hosts AND Localities: Birulia kishinouyei (Yokoya, 1930), Eualus fabricii (Kröyer, 1841), E. gaimardii (H. Milne Edwards,
1837), E. pusiolus (Kröyer, 1841), E. suckleyi (Stimpson, 1864), Heptacarpus brevirostris (Dana, 1852), H. herdmani (Walker, 1898), Hippolyte varians Leach, 1814, Lebbeus groenlandicus (Fabricius, 1775), Lebbeus polaris (Sabine, 1824), L. cf. spinirostris (Kobyakova, 1936), Spirontocaris arcuata Rathbun, 1902, S. holmesi Holthuis, 1947, S. lamellicornis (Dana, 1852), S. lilljeborgii (Danielssen, 1859), S. murdochi Rathbun, 1902, S. phippsii (Kröyer, 1841), S. spinus (Sowerby, 1805) (Hippolytidae) and Pandalopsis aleutica Rathbun, 1902, P. dispar Rathbun, 1902, Pandalus borealis Kröyer, 1838, $P$. goniurus Stimpson,1860, P. jordani Rathbun, 1902, P. montagui Leach, 1814 (Pandalidae), from Greenland, Iceland, Ireland, England, Denmark, Norway, Arctic Ocean, White Sea, Barents Sea, Sea of Okhotsk, Bering Sea, Japan, Korea, Yellow Sea, Taiwan, Kodiak, Alaska to Puget Sound, Washington, Ellsmere Island, Baffin Bay, Gulf of St. Lawrence, Nova Scotia, Maine to Cape Cod Bay, Massachusetts, $60 \mathrm{~m}$ (Yellow Sea), 506-680 $\mathrm{m}$ (Taiwan) (most other depths not recorded).

Remarks: Bopyroides hippolytes has been described many times in detail (see Markham, $1985 \mathrm{a}$, for a more complete synonymy and discussion). The synonymy list provided here includes only select references published after Markham (1985a). All hosts are in Hippolytidae and Pandalidae. Boyko (2004) recorded this species from Chinese waters infesting $L e b$ beus cf. spinirostris (Kobjakova) off Taiwan. The present specimens conform well to previous descriptions of this species, but the host and locality are new records. Birulia kishinouyei has not previously been reported as hosting any bopyrid.

\section{Bopyroides shiinoi Rybakov and Andeev, 1991 \\ Figure 12}

Bopyroides hippolytes: Shiino, 1937a: 293296, fig. 1 [Japan, infesting Spirontocaris alcimede de Man, 1906 (= Heptacarpus geniculatus (Stimpson, 1860)), S. mororani Rathbun, 1902 (= S. ochotensis (Brandt, 1851), S. pandaloides Stimpson (= Heptacarpus pandaloides (Stimpson, 1860))] (not Bopyroides hipplolytes Kröyer, 1838). 

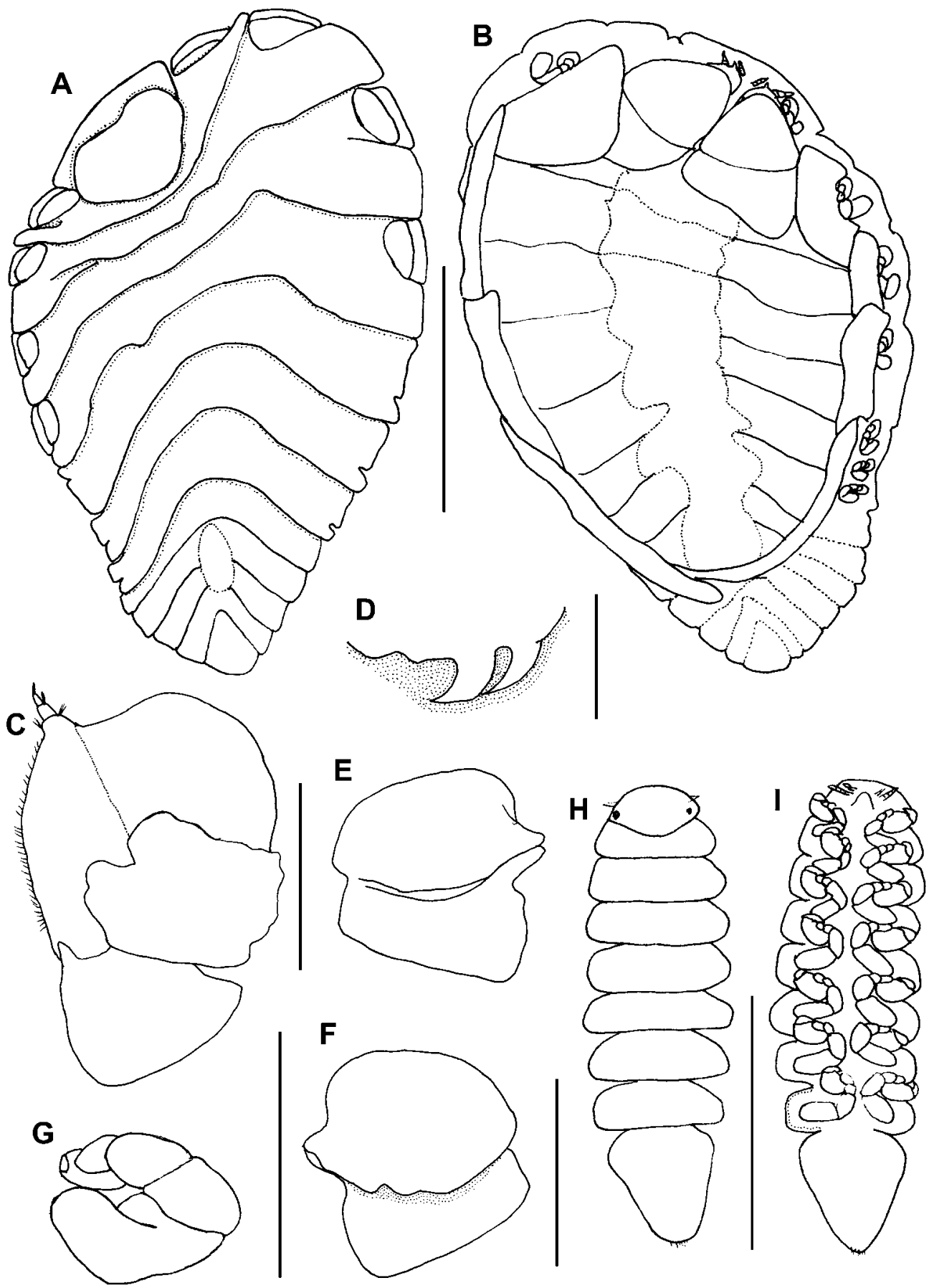

Fig. 12. Bopyroides shiinoi Rybakov and Andeev, 1991, reference female (CIEHI560901) (A-G): A. Dorsal view. B. Ventral view. C. Left maxilliped, external view. D. Left side of barbula. E. Left oostegite 1, external view. F. Left oostegite 1, internal view. G. Left pereopod 1. Reference male (CIEHI560902) (H, I): H. Dorsal view. I. Ventral view. Scale: $1 \mathrm{~mm}$ (A, B); $0.25 \mathrm{~mm}$ (C, D, G); $0.5 \mathrm{~mm}$ (E, F, H, I); $0.25 \mathrm{~mm}(\mathrm{G})$. 
Bopyroides shiinoi Rybakov and Andeev, 1991: 169-171 [Peter the Great Bay, Sea of Japan, infesting Heptacarpus camtschaticus (Stimpson, 1860), H. geniculata longirostris (Kobjakova) $(=H$. longirostris (Kobyakova, 1936)), and $H$. grebnitzkii Rathbun, 1902]; Boyko, 2004: 692-693 (mention, no new records); An, 2006: 79-80, fig. 35.

Material Examined: Infesting Hippolyte sp. (Hippolytidae), 1 ㅇ (CIEHI560901), 1 đ (CIEHI560902), Sea Island, Dalian City, Jiangsu Province, $123^{\circ} 15^{\prime}$ E, $39^{\circ} 00^{\prime}$ N, 27 September 1956.

Description: Female (CIEHI560901): Length $4.86 \mathrm{~mm}$, maximal width $3.60 \mathrm{~mm}$, head length $0.84 \mathrm{~mm}$, head width $1.28 \mathrm{~mm}$, sinistrally distorted $36^{\circ}$ (fig. 12A, B).

Head ovate, anterior edge bilobate, frontal lamina present, eyes absent (fig. 12A). Maxilliped (fig. 12C) with setose, articulated palp, inner edge fringes with setae. Barbula (fig. 12D) with two pairs of sharp, elongate falcate lateral projections on each side.

Pereon broadest across third pereomere (fig. 12A). Narrow rudimentary coxal plates on first four pereomeres of both sides. Lateral margin of pereomeres 5-7 indented (fig. 12A). Brood pouch completely open (fig. 12B). Oostegite 1 (fig. 12E, F) with two equally long articles, internal ridge almost smooth, posterolateral point blunt and directed laterally; fifth oostegite longest. Pereopods with subequal size and structure (fig. 12G), blunt dactyli, bases with carinae. Pleon of five pleomeres, fused medially. Pleopods and uropods lacking.

DesCRIPTION: Male (CIEHI560902): Length $1.87 \mathrm{~mm}$, maximal width (across pereon 5) $0.58 \mathrm{~mm}$, head width $0.34 \mathrm{~mm}$, pleonal length $0.51 \mathrm{~mm}$. All pereon segments distinct, pleomeres fused (fig. 12H, I). Head a flattened ellipse (fig. $12 \mathrm{H}$ ), eyes in posterolateral corners (fig. 12H). Antennule of three articles, antenna of five articles, terminally setose, extending beyond margins of head (fig. 12I). Pereomeres subequal in width, lacking midventral projections (fig. 12I). Pereopods with subequal size and structure (fig. 12I). Pleon completely fused, pleopods and uropods lacking (fig. 12I).

Hosts and Localities: Infesting Heptacarpus geniculatus (Stimpson, 1860), Heptacarpus pandaloides (Stimpson, 1860), Hippolyte sp., Spirontocaris ochotensis (Brandt, 1851) (Hippolytidae), Japan and Jiangsu Province, China.

Remarks: Shiino (1937a) recorded Bopyroides hippolytes infesting three Spirontocaris spp. from Japan, but this material was considered as belonging to $B$. shiinoi by Rybakov and Avdeev (1991), which was described from a more northerly locality in the Sea of Japan and from different hippolytid hosts. Rybakov and Avdeev (1991) noted that the most obvious difference between $B$. hippolytes and B. shiinoi is in the fusion of the terminal pleomeres. The present female does not have tubercular pleopods but does have fusion of the last two pleomeres, suggesting that it is conspecific with $B$. shiinoi. The host of the present specimens must be new, as no species of Hippolyte was previously known as a host for $B$. shiinoi, but this host specimen is not identifiable beyond the genus level.

\section{KEY TO THE THREE SPECIES OF BOPYROIDES STIMPSON, 1864}

1a. Pleon of five pleomeres (last two pleomeres fused) . . B. shiinoi Rybakov and Avdeev, 1991

1b. Pleon of six pleomeres ............ 2

2a. Sixth pleomere extended and produced into two divergent rami . . B. cluthae (Scott, 1902)

2b. Sixth pleomere not extended, terminally smooth, round .. B. hippolytes (Kröyer, 1838)

\section{Capitetragonia Pearse, 1953}

Diagnosis (modified from Markham, 1985a): Female: All body segments distinct. Head extended and produced anterolaterally; barbula with two pairs of lateral projections, both longer than wide; maxilliped lacking palp. Five or seven oostegites; oostegite 1 approximately as wide as long, extended into posterolateral projection at least $1 / 5$ of total length; coxal plates absent. Pleon of five or six pleomeres divided by deep notches along both sides; four pairs of flaplike biramous pleopods; no uropods.

Male: Body less than three times as long as broad, sides subparallel. Head, pereomeres, and pleon distinct. No midventral tubercles. Pleon fused, margins undulate, wider than adjacent pereomeres, much shorter than 
wide; five pairs of uniramous, flap like pleopods; no uropods.

TYPE SPECIES: Capitetragonia asperotibialis Pearse, 1953 (= Bopyrus alphei Richardson, 1900).

OTHER SPECIES: Capitetragonia elliptica (Markham, 1992), n. comb.

Remarks: Markham (1985a) erected Probopyria for the single species Bopyrus alphei Richardson, 1900. He examined the syntypes of Capitetragonia asperotibialis Pearse, 1953 (USNM 93720, see Pearse, 1953), and concluded they were conspecific with $B$. alphei. One of us (CBB) has also examined these syntypes and we concur with Markham's (1985a) conclusion as to this synonymy. However, because the type species of Capitetragonia and Probopyria are synonyms of each other, the correct name for the genus must be Capitetragonia, while the correct name for the type species is Capitetragonia alphei (Richardson, 1900).

Capitetragonia elliptica (Markham, 1992), n. comb.

Probopyria elliptica Markham, 1992a: 283285, figs. 6-7 [Hong Kong, infesting Alpheus malleodigitus (Bate, 1888)]; Li, 2003: 140, 153, 158.

Material Examined: None.

Hosts AND Localities: Infesting Alpheus malleodigitus (Bate, 1888) (Alpheidae), Hong Kong.

REMARKs: Markham (1992a) provisionally placed this species in Probopyria because the female has seven pairs of oostegites, known only in two other species of bopyrines (see Remarks under Septembopyrina, n. gen.), while the type species has the more usual five pairs. The male is much more similar, although that of $P$. elliptica has one fewer pleomere.

\section{Discorsobopyrus Boyko, 2004}

Diagnosis (after Boyko, 2004): Female: body ovate, one side of pereon slightly longer than other; head triangular, weakly produced with narrow frontal lamina. Antennae and antennules reduced to single segment each. Maxilliped with stout, distally rounded spur; palp lacking. Oostegite 1 proximal lobe ovate, distal lobe subtriangular, internal ridge smooth. Pereon composed of seven pereomeres, broadest across third pereomere. Coxal plates well developed on both sides, all elongate. Dorsolateral bosses well developed on some pereomeres, indistinct on others. Tergal projections lacking. Oostegites nearly completely enclosing marsupium. Basis of all pereopods bearing pronounced rounded medial boss; propodus with cup for insertion of dactylus. Pleon with five pleomeres plus pleotelson; first through fifth pleomeres with uniramous elongate pleopods and uniramous, short subquadrate lateral plates (some indistinct); edges and surfaces of all lateral plates smooth; pleopods smooth, uropods lacking.

Male: Head ovate, fused with first segment of pereon. Body shape elongate; fourth pereomere broadest; first three directed slightly anterolaterally, fourth through sixth laterally directed, seventh directed slightly posterolaterally. Posterior pereopods slightly larger. Pleon with one segment; faint lateral indication of segmentation and tapered pleotelson tip. Midventral tubercles on second to seventh pereomeres, pleopods and uropods lacking.

Type Species: Bopyrus stebbingi Nierstrasz and Brender à Brandis, 1923, by original designation.

Other SPecies: None.

\section{Discorsobopyrus stebbingi (Nierstrasz and Brender à Brandis, 1923)}

Bopyrus stebbingi Nierstrasz and Brender à Brandis, 1923: 97-98, pl. 7, fig. 23a-c [Indonesia, infesting unknown host]; Chopra, 1923: 518, 541-542; Bourdon, 1968: 372.

Discorsobopyrus stebbingi: Boyko, 2004: 694 697, figs. 11-13 [Taiwan, Indonesia, infesting Heterocarpus sibogae de Man, 1917]; Markham, 2010: 159.

? "unidentified bopyrid" Li and Chan, 2014: 135 [Philippines, infesting $H$. sibogae].

\section{Material Examined: None.}

Hosts and Localities: Infesting Heterocarpus sibogae de Man, 1917 (Pandalidae), Philippines, Indonesia, and Taiwan.

Remarks: The unidentified bopyrid on a specimen of $H$. sibogae collected from the 
Philippines and cited by Li and Chan (2014) may belong to this species or possibly to Pseudione magna Shiino, 1951 (see Markham, 2010); no other bopyrid is known from this host species.

\section{Litobopyrus Markham, 1982}

Diagnosis (after Markham, 1982): Female: Body distorted; head distinct from pereon; frontal lamina obscure; maxilliped with tuft of setae, palp lacking; barbula of two moderately long projections on each side; oostegite 1 lacking internal ornamentation and posterolateral point; lateral plates elongate; five pairs of biramous pleopods with endopodites reduced to sessile knobs; uropods broad and long.

Male: Greater than three times as long as broad; head medially fused with first pereomere; pereopods subequal, with all articles distinct; pleomeres fused, lacking appendages.

TYPE SPECIES: Litobopyrus longicaudatus Markham, 1982, by original designation.

Other SPECIEs: None.

Litobopyrus longicaudatus Markham, 1982

Litobopyrus longicaudatus Markham, 1982: 346-348, fig. 15 [Hong Kong, infesting Athanas sp.]; Morton, 2003: 37; Li, 2003: 140, 153, 157.

Material Examined: None.

Hosts and Localities: Infesting Athanas sp. (Alpheidae), Hong Kong.

Remarks: The taxonomic position of $L$. longicatudatus is unclear, as the female characters are more like those of the bopyrine Urobopyrus Richardson, 1904, while the male characters more resemble those of the pseudionine Pleurocrypta Hesse, 1865.

\section{Parabopyrella Markham, 1982}

Diagnosis: Female: Head fused with first pereomere except at anterolateral corners; maxilliped with setose palp; barbula with one or two pairs of lateral projections on each side; oostegite 1 with unadorned or sparsely digitate internal ridge; dorsolateral bosses usually on first four pereomeres; pleon of six segments indicated by lateral indentations; pleotelson rounded or produced into posterolateral points; five pairs of flaplike biramous pleopods; uropods absent.

Male: Head usually fused with first pereomere; eyes present or absent; pereopods subequal in size and shape; pleon variously fused; first pleomere as broad as seventh pereomere or much broader; pleopods tuberculate if present; uropods usually absent.

TyPe SPECIES: Bopyrella mortenseni Nierstrasz and Brender à Brandis, 1929, by original designation.

Other Species: $P$. angulosa (Bourdon, 1980a), P. angusta (Shiino, 1936), P. australiensis (Bourdon, 1980a), P. barnardi (Nierstrasz and Brender à Brandis, 1931), $P$. bonnieri (Nierstrasz and Brender à Brandis, 1923), P. choprai (Nierstrasz and Brender à Brandis, 1929), P. crenulata (Shiino, 1939), $P$. cuspidata, n. sp., P. delagoae (Bourdon, 1982), P. distincta (Nierstrasz and Brender à Brandis, 1923), P. elongata (Shiino, 1949), P. essingtoni (Bourdon and Bruce 1983), P. hodgarti (Chopra, 1923), P. incisa (Chopra, 1923), P. indica (Chopra, 1923), P. intermedia (Nierstrasz and Brender à Brandis, 1923), $P$. lata (Nierstrasz and Brender à Brandis, 1929), P. megatelson (Nierstrasz and Brender à Brandis, 1929), P. nierstraszi (Chopra, 1930), P. pacifica (Shiino, 1933), P. perplexa Markham, 1990, P. richardsonae (Nierstrasz and Brender à Brandis, 1929), P. saronae (Bourdon and Bruce, 1979), P. setoensis (Shiino, 1939), P. symmetros, n. sp., $P$. tanyensis (Bourdon, 1979), and P. thomasi (Nierstrasz and Brender à Brandis, 1929).

Remarks: Although Markham (1985a) purported to erect this genus and restricted the definition of Bopyrella, transfering four western Atlantic species and 20 Indo-West Pacific species to Parabopyrella, in fact the genus name is available from Markham (1982) where it was cited as "in press" but with a type species, Bopyrella mortenseni, designated (the same species was "designated" as the type species in Markham, 1985a). Only one other taxon, Bopyrella deformans indica Chopra, 1923, was listed as included in the genus when it was introduced by Markham (1982). Markham (1985a) erroneously referred to the 1982 usage of the name as a nomen nudum.

Parabopyrella can be distinguished from Bopyrella in that females of Parabopyrella 
have lateral indentations that indicate the pleomeres on both sides while the pleomeres of females in Bopyrella are completely fused. Previously, this genus included 26 species, all known from hosts in Alpheidae and Hippolytidae. Two new species are described herein.

According to the shape of the distal margin of the pleotelson of the female, species of Parabopyrella can be divided into three groups (after Bourdon, 1980a). "A" group has the pleotelson tip entire, truncate, or convex and produced into a point in the median and includes six species ( $P$. angulosa, $P$. choprai, $P$. crenulata, $P$. delagoae, $P$. perplexa, $P$. symmetros, n. sp.). "B" group has the pleotelson tip entire, but convex and produced into a rounded distal region and includes eight species ( $P$. angusta, $P$. essingtoni, $P$. mortenseni, $P$. nierstraszi, $P$. richardsonae, $P$. saronae, P. setoensis, P. tanyensis). "C" group has the pleotelson incised medially, with divergent posterolateral lobes. Within the "C" group, there are four types: " $\mathrm{C} 1$ " group with the medial incision shallow and the distal ends of the lobes quadrate, and includes five species ( $P$. australiensis, P. barnardi, P. cuspidata, n. sp., P. elongata, P. pacifica), "C2" group with the medial incision shallow, but distal ends of the lobes rounded, and includes three species $(P$. distincta, $P$. intermedia, $P$. thomasi), "C3" group with the medial incision deep and the distal ends of lobes pointed and long, and includes two species $(P$. lata, $P$. megatelson), "C4" group with the medial incision shallow but produced into two small points, and includes four species ( $P$. bonnieri, $P$. hodgarti, $P$. incisa, $P$. indica).

\section{Parabopyrella choprai (Nierstrasz and Brender à Brandis, 1929)}

Bopyrella choprae Nierstrasz and Brender à Brandis, 1929: 29-30, figs. 32-33 [Nicobar Islands, infesting Alpheus lottini GuérinMéneville, 1838); Taiwan, infesting Lysmata vittata (Stimpson, 1860) or Synalpheus sp. (see below)]; Chopra, 1930: 134, 138; Shiino, 1933: 282-283.

Bopyrella choprai: Bourdon, 1980a: 187, 213215, fig. 13.

Parabopyrella choprai: Kensley and Chan, 2001: 481; Boyko, 2004: 677; Boyko, 2006: 43; Liu, 2008: 692.
Material Examined: None.

Hosts and Localities: Infesting Alpheus lottini Guérin-Méneville, 1838) (Alpheidae) and Lysmata vittata (Stimpson, 1860) (Hippolytidae) or Synalpheus sp. (Alpheidae), Nicobar Islands and Taiwan.

Remarks: As pointed out by Boyko (2006), there is some doubt as to the host in Taiwan as given by Nierstrasz and Brender à Brandis (1929), but both hippolytid and alpheid shrimp are known as hosts of Parabopyrella species, so neither can be ruled out (although the fact that the host from the Nicobar Islands was an alpheid suggests that the Synalpheus sp. is more likely). Bourdon (1980a) changed the spelling of the specific name without comment, presumably because it is generally agreed that Chopra was a man. Although it is possible that Nierstrasz and Brender à Brandis (1929) treated the name as if it were a first-declension Latin noun, which are usually but not always feminine, and used the appropriate genitive, this seems unlikely. On the second page of their paper, they remarked "Die späteren Forscher, wie Miss Richardson, Chopra, und auch wir selbst, haben das Prinzip Bonnier's übernommen aus Armut, weil es kein besseres gibt." The lack of an honorific for Chopra, as was provided for Richardson, suggests that Nierstrasz and Brender à Brandis thought Chopra was a male but does not explain why the -ae ending was used.

Parabopyrella cuspidata, n. sp. Figure 13

Parabopyrella cuspidatus An, 2006: 85-86, fig. 40 (unavailable name).

Material Examined: Infesting Alpheus digitalis De Haan, 1844, holotype o (CIEAL 560301), allotype ơ (CIEAL560302), Haimen, Jiangsu Province, $121^{\circ} 15^{\prime} \mathrm{E}, 31^{\circ} 54^{\prime} \mathrm{N}, 12-14$ March 1956, coll. Ruiyu Liu and Zhengang Fan.

Description: Holotype female (CIEAL 560301): Length $9.24 \mathrm{~mm}$, maximal width $5.53 \mathrm{~mm}$, head length $2.06 \mathrm{~mm}$, head width $2.1 \mathrm{~mm}$, distorted $22^{\circ}$ (fig. 13A, B).

Head fused with first pereomere except in anterolateral corners, obscure posterior 

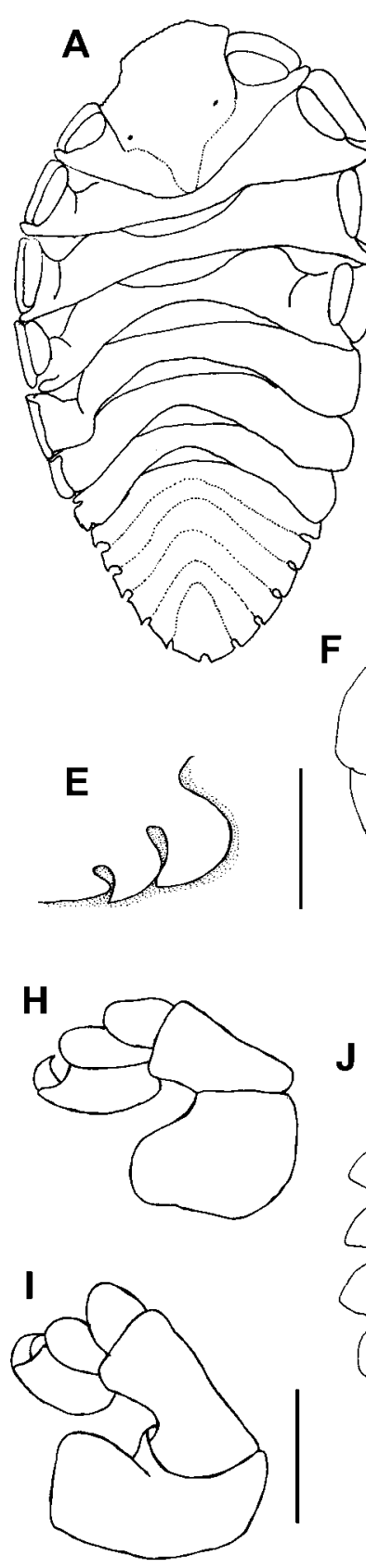

B
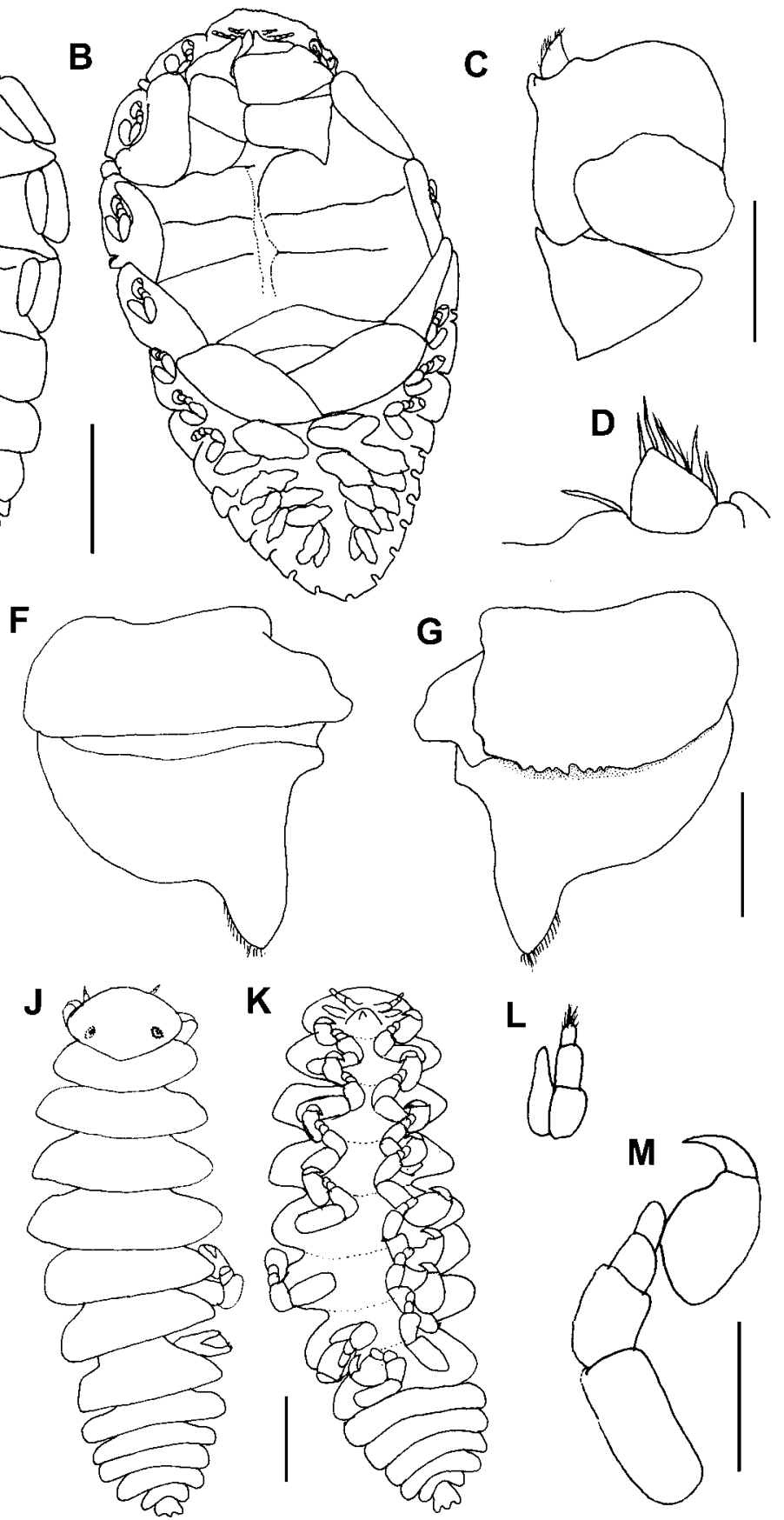

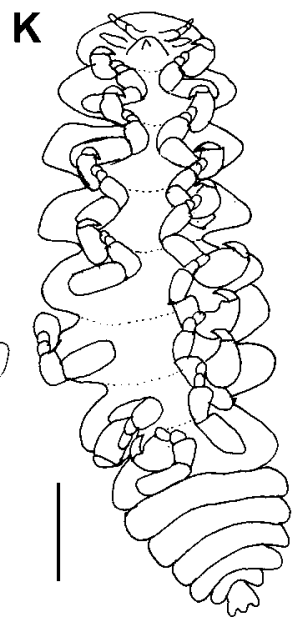

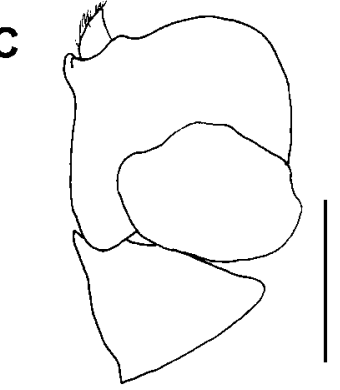

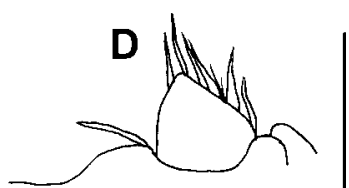

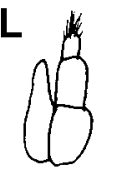

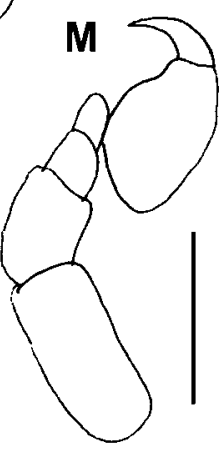

Fig. 13. Parabopyrella cuspidata, n. sp., holotype female (CIEAL560301) (A-I): A. Dorsal view. B. Ventral view. C. Left maxilliped, external view. D. Palp of maxilliped, internal view. E. Left side of barbula. F. Left oostegite 1, external view. G. Left oostegite 1, internal view. H. Right pereopod 2. I. Right pereopod 6. Allotype male (CIEAL560302) (J-M): J. Dorsal view. K. Ventral view. L. Right antennae and antennule. M. Left pereopod 7. Scale: $2 \mathrm{~mm}$ (A, B); $0.5 \mathrm{~mm}(\mathrm{C}, \mathrm{E}-\mathrm{G}) ; 0.25 \mathrm{~mm}(\mathrm{D}, \mathrm{H}-\mathrm{K}) ; 0.15 \mathrm{~mm}$ (L, M). 
margin sharply curved and anterior margin of head irregular. Small black eyes near posterior margin of head (fig. 13A). Antennule of three articles, antenna of five articles. Maxilliped articulated with triangular palp laterally fringed with setae (fig. 13C, D). Barbula with two pairs of short falcate lateral projections on each side (fig. 13E).

Pereon broadest across third pereomere (fig. 13A). Pereomeres 2-5 medially fused. Coxal plates well developed on left side of all pereomeres and on right side of first four pereomeres. Round dorsolateral bosses on first four pereomeres. Brood pouch widely open (fig. 13B). Oostegite 1 (fig. $13 \mathrm{~F}$, G) with two articles, internal ridge bearing small simple projections, posterolateral point directed straight backward, distal portion of posterior edge fringed with setae. Posterior pereopods slightly larger (fig. $13 \mathrm{H}, \mathrm{I})$, carpi and meri smooth, dactyli short, bases of all pereopods produced into lobes. Pleon of six pleomeres, segments indicated by dorsal sutures and deep lateral indentations (fig. 13A), first five bearing biramous flaplike pleopods (fig. 13B), sixth pleomere incised medially, uropods lacking (fig. 13B).

Description: Allotype male (CIEAL56 0302): Length $2.20 \mathrm{~mm}$, maximal width across pereomere $40.82 \mathrm{~mm}$, head width $0.47 \mathrm{~mm}$, head length $0.28 \mathrm{~mm}$. All segments distinct (fig. 13J, K). Head elliptical with curved posterior edge (fig. 13J), large black eyes near posterior margin of head (fig. 13J). Antennule of three articles with setae on distal article, antenna of one article, terminally smooth (fig. 13L). Pereomeres widest across fourth pereomere, lacking midventral projections (fig. 13K). All pereopods of similar size and structure, dactyli sharp but short (fig. 13M). Pleon of six distinct segments, without midventral projections, pleopods or uropods (fig. $13 \mathrm{~K})$. Sixth pleomere produced into two extend subacute lobes with medioventral anal cone (fig. 13K).

Etymology: The specific name, cuspidata, refers to the head of the female having a sharply curved posterior margin and an irregular anterior margin.
Host and Locality: Infesting Alpheus digitalis De Haan, 1844 (Alpheidae), Jiangsu Province, China.

Remarks: The new species belongs to the "C1" group with a medially incised pleotelson and can be distinguished from the other four species of the "C1" group by characters of oostegite 1, maxilliped, and the posterior margin of the head. The male of the new species differs from those of all other Parabopyrella species by the characters given below in (4). Parabopyrella cuspidata, n. sp., is most closely related to $P$. barnardi, but (1) the female of the new species bears a pleon with dorsal sutures and deep indentations on both sides (the female of $P$. barnardi has the pleon fused dorsally and with only the left side deeply indented), (2) the maxilliped of the new species has a triangular palp ( $P$. barnardi with cylindrical palp), (3) the posterolateral point of oostegite 1 of the new species is sharp and backwardly directed (that of $P$. barnardi round and laterally directed), (4) the male of the new species has distinct pleomeres and laterally separated lobes on the pleotelson (male of $P$. barnardi with fused pleomeres and rounded pleotelson).

\section{Parabopyrella distincta (Nierstrasz and Brender à Brandis, 1923) Figure 14}

Bopyrella distincta Nierstrasz and Brender à Brandis, 1923: 97, pl. 6, fig. 22 a-d [type locality: Pulau Kaniungan-Ketjil, Indonesia; infesting Synalpheus amboinae (Zehntner, 1984) = Synalpheus stimpsonii (de Man, 1888]; Chopra, 1927: 121-122, figs. 1-2 [Tamban, Tamil Nadu, India; infesting unidentified alpheid]; Shiino, 1936: 159; Shiino, 1939: 93; Shiino, 1949a: 49; Bourdon, 1980a: 205-208, fig. 9 [redescription of holotype].

Parabopyrella distincta: Markham, 1985a: 67 [transfer to Parabopyrella]. -An, 2006: 82-83, fig. 37.

Material Examined: Infesting Alpheus sp., 1 ㅇ (CIEAL550001), 1 đo (CIEAL550002), 1955, Hainan Province, Qionghai Province.

DesCription: Female (CIEAL550001): Length $7.52 \mathrm{~mm}$, maximal width $5.53 \mathrm{~mm}$, 


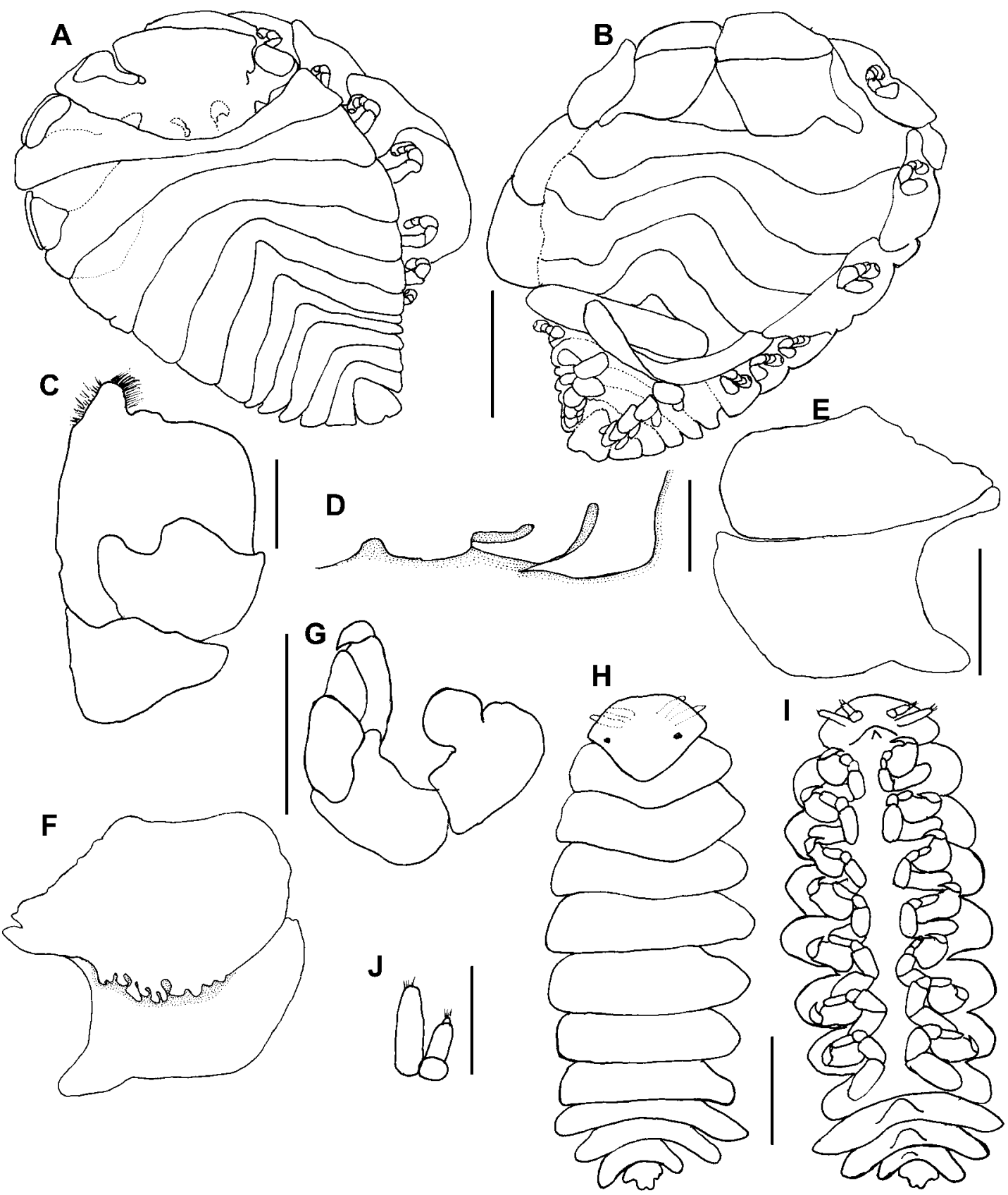

Fig. 14. Parabopyrella distincta (Nierstrasz and Brender á Brandis, 1923), reference female (CIEAL550001) (A-G): A. Dorsal view. B. Ventral view. C. Left maxilliped, external view. D. Left side of barbula. E. Left oostegite 1, external view. F. Left oostegite 1, internal view. G. Right pereopod 7. Reference male (CIEAL550002) (H-J): H. Dorsal view. I. Ventral view. J. Right antennae and antennule. Scale: $2 \mathrm{~mm}(\mathrm{~A}, \mathrm{~B}) ; 1 \mathrm{~mm}(\mathrm{E}, \mathrm{F}) ; 0.5 \mathrm{~mm}$ (C, D, H, I, G); $0.25 \mathrm{~mm}(\mathrm{~J})$. 
head width $2.19 \mathrm{~mm}$, distorted $31^{\circ}$ (fig. 14A, B).

Head fused with first pereomere, with anterolateral corner notch. Frontal lamina and eyes lacking (fig. 14A). Maxilliped (fig. 14C) with unarticulated setose palp. Barbula (fig. 14D) with two pairs of smooth falcate lateral projections on each side and shallow median indentation in center.

Pereon broadest across third pereomere (fig. 14A). Coxal plates rudimentary on short side, but well developed on first three pereomeres on long side. First three pereomeres of left side and only first pereomere of right side with dorsolateral bosses. Brood pouch completely open (fig. 14B). Oostegite 1 (fig. $14 \mathrm{E}, \mathrm{F})$ with two equally long articles, internal ridge bearing simple small projections, posterolateral point sharply directed laterally. Fifth oostegite much longer than other oostegites (fig. 14B). Pereopods of similar size, basis of each pereopod with carina (fig. 14G). Pleon of six pleomeres, bearing five pairs of biramous flaplike pleopods. Pleotelson medially incised, but rami distally round, uropods lacking.

DesCRIPTION: Male (CIEAL550002): Length $2.11 \mathrm{~mm}$, maximal width (across pleon 1) 0.82 $\mathrm{mm}$, head width $0.41 \mathrm{~mm}$, pleonal length 0.26 $\mathrm{mm}$. All pereomeres distinct (fig. $14 \mathrm{H}, \mathrm{I}$ ). Head ovate, anterior margin rounded, posterior margin curved (fig. 14H), black eyes near posterior margin (fig. 14H). Antenna of one article, antennule of three articles, both terminally setose (fig. 14J). Pereomeres subequal in width, lacking midventral projections (fig. 14I). Pereopods subequal in size, but dactyli of first five pairs larger than others, carpi of first pereopod rounded, others of elongate columnar form (fig. 14I). First three pleomeres distinct, with midventral tubercles. Last two pleomeres fused into single piece, but segments indicated by lateral indentations, without uropods (fig. 14H, I).

Hosts and Localities: Infesting Alpheus sp. (possibly more than one species), Synalpheus stimpsonii (de Man, 1888) (Alpheidae), Hainan Province, Qionghai Province, China and Pulau, Indonesia, $11 \mathrm{~m}$.

REMARKs: Nierstrasz and Brender à Brandis (1923) described Bopyrella distincta based on a single female collected by the Siboga-Expedition. Chopra (1927) reported on a pair of specimens from southeast India and described the male for the first time. Bourdon (1980a) redescribed and figured the female holotype specimen, incorrectly citing the host as Synalpheus ambonicae (sic). Markham (1985a) reviewed Bopyrella, and transferred this species to Parabopyrella. The present specimens are therefore only the third female and second male to be reported. The female conforms well to the holotype, but differ in some minor characters, such as the pleon of the present female not fused medially, and the posterolateral point of oostegite 1 more elongate and directed laterally.

\section{Parabopyrella elongata (Shiino, 1949)} Figure 15

Bopyrella elongata Shiino, 1949a: 45-50, fig. 1 a-c. [Japan; infesting "Crangon bis-incisus (De Haan)" (= Alpheus bisincisus De Haan, 1849]. - Bourdon, 1980a: 194-196, fig. 4, tab. 1 [Queensland, Australia; infesting Alpheus sp.]

Parabopyrella elongata: Markham, 1985a: 67 [transfer to Parabopyrella]. -An, 2006: 83-84, fig. 38.

Material Examined: Infesting Alpheus sp., 1 ㅇ (CIEAL851001a), 1 o (CIEAL851001b), Xiamen City, $118^{\circ} 15^{\prime} \mathrm{E}, 24^{\circ} 25^{\prime} \mathrm{N}, 15$ October 1985.

DESCRIPTION: Female (CIEAL851001a): Length $7.03 \mathrm{~mm}$, maximal width $4.49 \mathrm{~mm}$, head length $1.46 \mathrm{~mm}$, head width $1.63 \mathrm{~mm}$, pereon length $2.84 \mathrm{~mm}$, distorted $21^{\circ}$ (fig. $15 \mathrm{~A}, \mathrm{~B})$. Head subquadrate, fused with first pereomere except in anterolateral corners, with thin frontal lamina. Black eyes near anterolateral corners (fig. 15A). Antennule of two articles, antenna of three articles, distally setose. Maxilliped (fig. 15C) with short stout setose palp. Barbula (fig. 15D) with two pairs of short smooth lateral projections on each side, small round tubercle near median.

Pereon segments distinct, broadest across third pereomere (fig. 15A). Coxal plates and dorsolateral bosses on first four pereomeres. Brood pouch widely open (fig. 15B). Oostegite 1 (fig. $15 \mathrm{E}, \mathrm{F}$ ) with nearly smooth internal ridge, posterolateral point sharp, directed posteriorly. Pereopods larger posteriorly (fig. $15 \mathrm{G})$, bases of all pereopods with small 

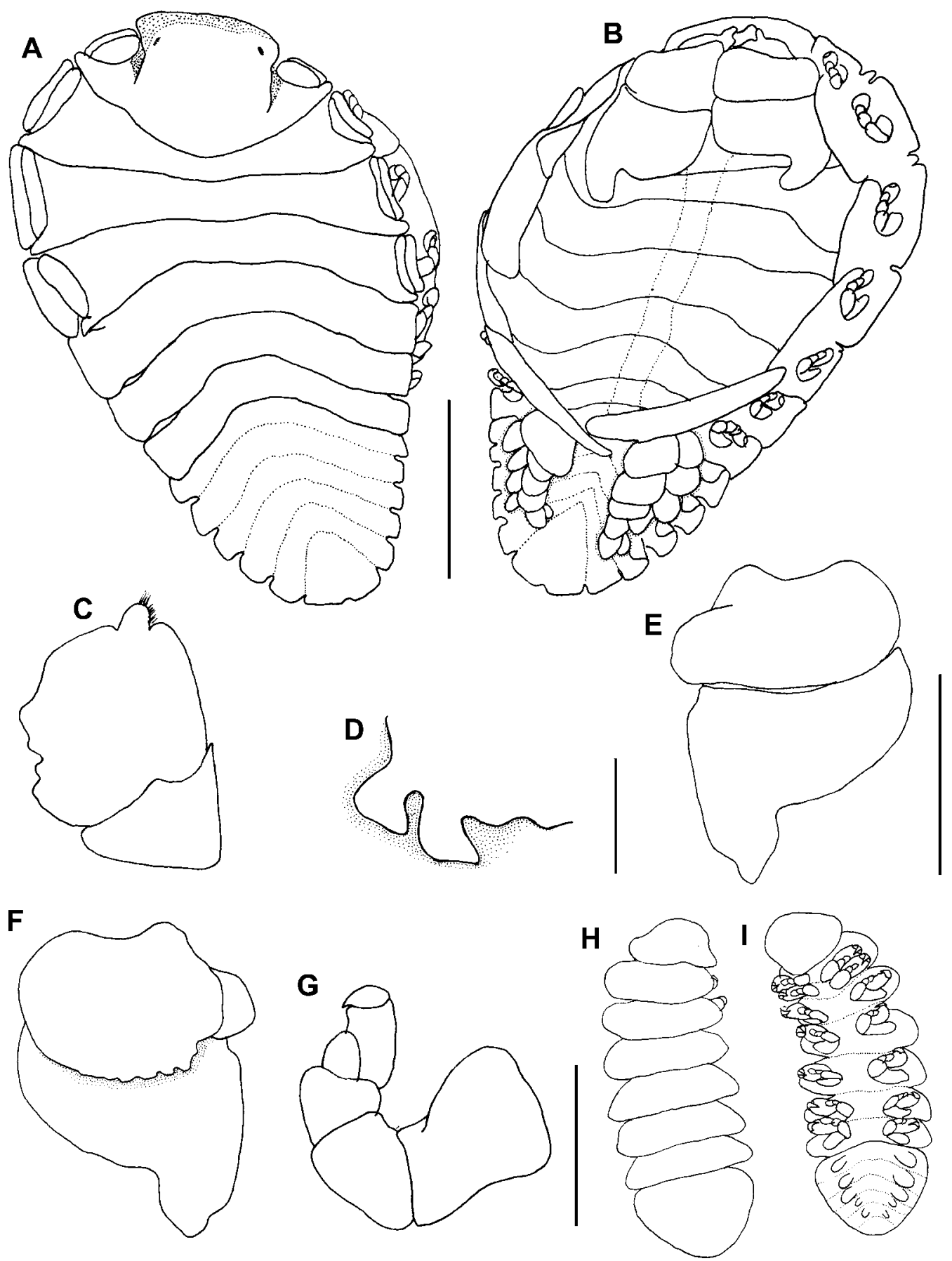

Fig. 15. Parabopyrella elongata (Shiino, 1949), reference female (CIEAL851001a) (A-G): A. Dorsal view. B. Ventral view. C. Right maxilliped, external view. D. Right side of barbula. E. Right oostegite 1, external view. F. Right oostegite 1, internal view. G. Right pereopod 7. Reference male (CIEAL851001b) (H, I): H. Dorsal view. I. Ventral view. Scale: $2 \mathrm{~mm}$ (A, B); $1 \mathrm{~mm}$ (E, F, H, I); $0.5 \mathrm{~mm}$ (C, D); $0.35 \mathrm{~mm}(\mathrm{G})$. 
carina. Pleon of six pleomeres, segments indistinct but indicated by dorsal sutures and lateral deep indentations. First five pleomeres with flaplike biramous pleopods and weakly developed lateral plates; uropods absent.

DESCRIPTION: Male (CIEAL851001b): Length $1.63 \mathrm{~mm}$, maximal width (across pereomere 7) $0.65 \mathrm{~mm}$, pleonal length $0.41 \mathrm{~mm}$ (fig. $15 \mathrm{H}, \mathrm{I})$. Head ovate, completely fused with first pereomere (fig. 15I), without eyes (fig. 15H). Antenna obscure. Pereomeres 2-7 distinct, with similar pereopods (fig. 15I). Pereomeres subequal in width, lacking midventral projections (fig. 15I). Pleon fused into single piece, without lateral indentations, ventral suture visible and indicative of pleomeres, five tubercular pleopods (fig. 15I), uropods lacking.

Hosts AND Locality: Infesting Alpheus bisincisus De Haan, 1849, Alpheus sp. (probably more than one species) (Alpheidae), Japan, Queensland, Australia, and Fujian Province, China.

Remarks: Shiino (1949a) described Bopyrella elongata infesting Alpheus bisincisus from Seto, Japan, and Bourdon (1980a) reported it infesting Alpheus sp. at Queensland; Markham (1985a) transferred it to Parabopyrella. The present specimens conform well to the redescription of Bourdon (1980a), but the male differs from both previously reported males of $P$. elongata. Shiino's (1949a) and Bourdon's (1980a) males have fused pleon segments but with the pleomeres indicated by lateral indentations. The present male has completely smooth lateral margins and has the pleomeres indicated by ventral sutures. Although the male differs in this respect from the other specimens, the female is very similar to the previously reported females and this material is therefore identified as P. elongata.

\section{Parabopyrella hodgarti (Chopra, 1923) Figure 16}

Bopyrella hodgarti Chopra, 1923: 416, 469, 473-475, fig. 10; pl. 14, figs. 7-12 [type locality Vizagapatam, Madras Presidency (Bay of Bengal) (= Visakhapatnam, Andhra Pradesh, India); infesting Alpheus crassimanus Heller, 1865 ( $=$ A. lobidens De Haan, 1849)]. - Shiino, 1949a: 47 (mention). -Barnard, 1955: 79, fig. 37b, c (in part; Inhambane, Mozambique; infesting
A. crassimanus (= A. lobidens). - Bourdon, 1968: 407-408 (mention). -Kensley, 1974: 261 (off Natal, South Africa; infesting Alpheus sp.). - Bourdon, 1980a: 190-191 (mention).

Parabopyrella barnardi australiensis: An, 2006: 81-82, fig. 36 (not Parabopyrella australiensis (Bourdon, 1980a)).

not Bopyrella hodgarti: Barnard, 1955: 79 (in part; Mozambique; infesting Hippolyte sp.).

Material Examined: Infesting Alpheus japonicus Miers, 1879, 1 क (CIEAL570601a), 1 đo (CIEAL570601b), Jiaozhou Bay, Qingdao, Shandong Province, $120^{\circ} 15^{\prime} \mathrm{E}, 36^{\circ} 15^{\prime} \mathrm{N}, 5.5$ m, 18 June 1957; 1 ㅇ, 1 ơ (CIEAL570602), Jiaozhou Bay, Qingdao, Shandong Province, $120^{\circ} 15^{\prime} \mathrm{E}, 36^{\circ} 15^{\prime} \mathrm{N}, 5.5 \mathrm{~m}, 18$ June 1957.

Infesting Synalpheus streptodactylus Coutière, 1905, 1 ㅇ (CIEAL760801) East China Sea, Stn. V-3, $123^{\circ} 00^{\prime} \mathrm{E}, 26^{\circ} 30^{\prime} \mathrm{N}, 105 \mathrm{~m}, 27$ August 1976, coll. Zhican Tang and Zhongyan Qi.

Description: Female (CIEAL570601a): Length $6.86 \mathrm{~mm}$, maximal width $4.69 \mathrm{~mm}$, head length $1.17 \mathrm{~mm}$, head width $1.49 \mathrm{~mm}$ (fig. 16A, B). Head an inverted trapezoid, without frontal lamina; eyes absent (fig. 16A). Antennule and antenna absent. Maxilliped (fig. 16C) with short straight and stout palp, long setae terminally. Barbula (fig. 16D) with two pairs of smooth falcate lateral projections on each side and shallow indentation near center.

Pereon broadest across third pereomere (fig. 16A). Boundary between head and first pereomere only visible laterally. Coxal plates small and only on first four pereomeres of both sides, those on left side slightly larger than those on right side. Brood pouch widely open, oostegite 1 and median part of barbula visible in ventral view (fig. 16B); oostegite 5 longest. Internal ridge of oostegite 1 (fig. $16 \mathrm{E}, \mathrm{F})$ bearing six to eight small digitate projections, posterolateral point rounded posteriorly. Pereopods larger posteriorly (fig. 16G). Pleon of six pleomeres, but sutures obscure, wide lateral indentations indicating pleomeres. Five pairs of triangular flaplike biramous pleopods, surfaces smooth, uropods lacking.

Description: Male (CIEAL570601b): Length $1.64 \mathrm{~mm}$, maximal width (across 


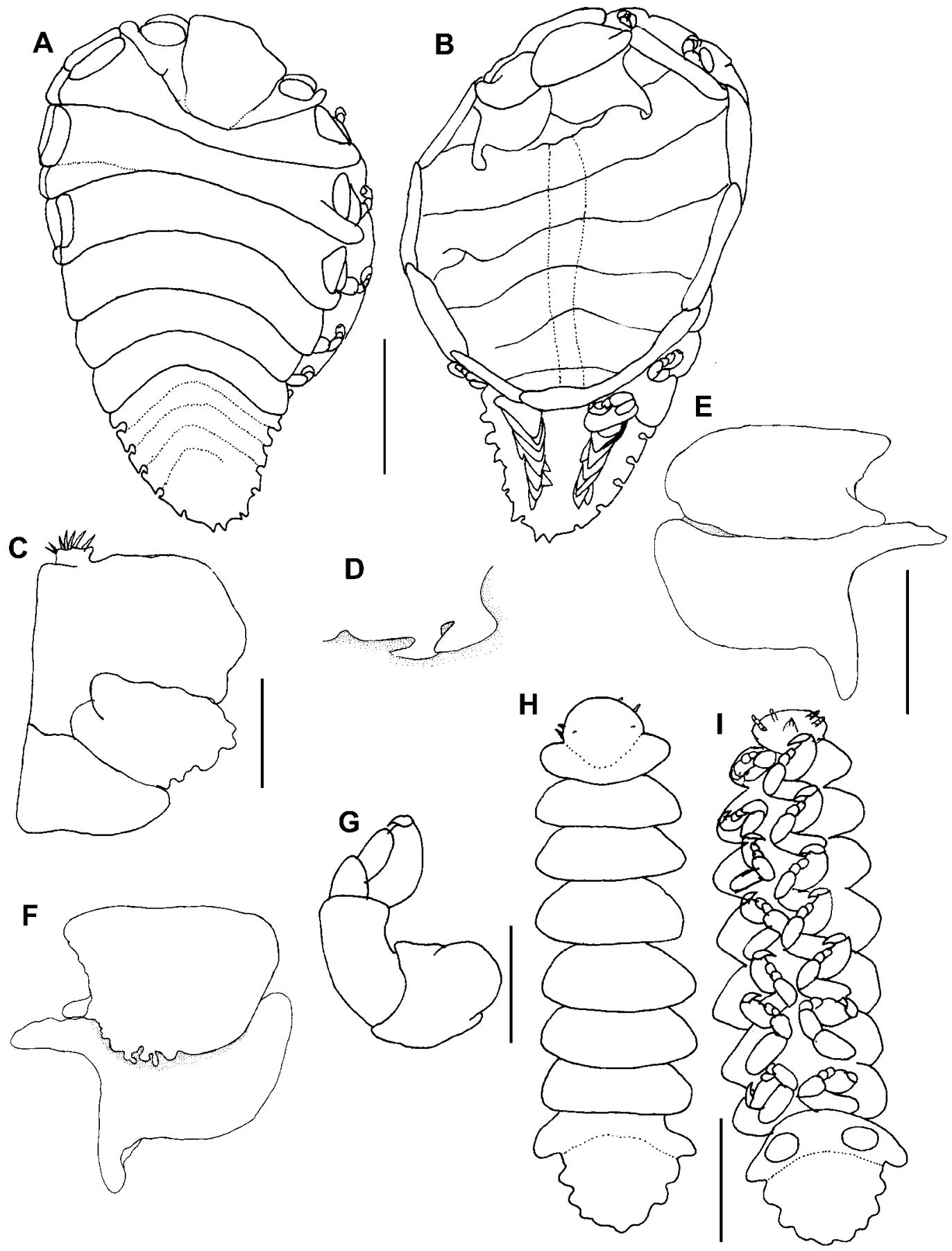

Fig. 16. Parabopyrella hodgarti (Chopra, 1923), reference female (CIEAL570601a) (A-G): A. Dorsal view. B. Ventral view. C. Left maxilliped, external view. D. Left side of barbula. E. Left oostegite 1, external view. F. Left oostegite 1, internal view. G. Left pereopod 1. Reference male (CIEAL570601b) (H, I): H. Dorsal view. I. Ventral view. Scale: $2 \mathrm{~mm}(\mathrm{~A}, \mathrm{~B}) ; 0.5 \mathrm{~mm}$ (C);1 mm (D-F); $0.35 \mathrm{~mm}(\mathrm{G}) ; 0.45 \mathrm{~mm}$ (H, I). 
pleomere 1) $0.54 \mathrm{~mm}$, head width $0.27 \mathrm{~mm}$, head and pleomere length $1.25 \mathrm{~mm}$. (fig. $16 \mathrm{H}, \mathrm{I})$. Head ovate, posterior edge curved, but boundary between head and first pereomere obscure (fig. $16 \mathrm{H}$ ), eyes present mediolaterally (fig. $16 \mathrm{H}$ ). Antennule of three articles, antenna of five articles, terminally smooth (fig. 16I). Pereomeres subequal in width, lacking midventral projections (fig. 16I). Pereopods smaller posteriorly, first three pereopods with largest dactyli, last two pereopods with smallest dactyli (fig. 16I). Pleon fused, segments indicated by strong lateral indentations, first pleomere widest with pair of large round tubercular pleopods, all other pleopods and uropods absent (fig. 16I).

Hosts and Localities: Infesting Alpheus japonicus Miers, 1879, A. lobidens De Haan, 1849, A. sp. indet., Synalpheus streptodactylus Coutière, 1905 (Alpheidae), Andhra Pradesh, India, Mozambique, South Africa, Shandong Province, China, East China Sea, 5.5-105 m.

REMARKs: This species was previously known from the western Pacific in the Bay of Bengal, Mozambique, and South Africa (Chopra, 1923; Barnard, 1955; Kensley, 1974). Chopra (1923) erroneously stated that a "single specimen" was collected but described both the male and female; both are syntypes because Chopra failed to designate a holotype.

This is first record from China, and both hosts are first recorded as bearing parasitic isopods. The present specimens conform well to the female syntype of Chopra (1923), but the male differs from the male syntype in that (1) the present males have only the first pleomere distinct and other pleomeres indicated by lateral indentations; but the syntype male has the first three pleomeres distinct with the others fused without any lateral indentations (the Mozambique male of Barnard (1955) is somewhat intermediate in this character with weak indications of segmentation on the first four pleomeres); (2) the present male has one pair of pleopods, but the syntype male lacks all pleopods (character state in Mozambique male unknown); (3) the present male has only the first pleomere wider than the pereon, but the syntype male has the first three pleomeres wider than the pereon (the Mozambique male is somewhat intermediate with pleomeres 2 and 3 wider than in the present specimen but not as wide as in the male syntype).

Based on the host and the morphological differences indicated above, it is very likely that the specimens reported by Barnard (1955) from Hippolyte sp. are distinct from $P$. hodgarti, but, as he did not describe or illustrate them, their identity is unknown.

\section{Parabopyrella indica (Chopra, 1923)}

"a subspecies of Hay's B. deformans" Chopra, 1922: 70.

Bopyrella deformans var. indica Chopra, 1923: 416, 420

Bopyrella deformans indica Chopra, 1923: 468-473, text fig. 9, pl. 14, fig. 1-6 [Pakistan and India, infesting Synapheus tumidomanus tumidomanus (Paul'son, 1875); NE of Sri Lanka, infesting Synapheus nilandensis Coutière, 1905]; Chopra, 1927: 119-121 [Gulf of Manaar, infesting alpheid sp.]; Chopra, 1930: 133; Monod, 1933: 236; Qazi, 1959: 55, 60; Savant, 1973: 331; Kruczynski and Menzies, 1977: 551, 556; Kensley, 2001: 222.

Synsynella deformans var. indica: Nierstrasz and Brender à Brandis, 1929: 4, 38, fig. 48 [Hong Kong, infesting Synalpheus sp.]; Monod, 1933: 227-232, figs. 50-51 [Red Sea, infesting alpheid sp.]; Shiino, 1949a: 49; Kruczynski and Menzies, 1977: 552.

"Chopra's 'sub-species"” Kruczynski and Menzies, 1977: 556.

Bopyrella indica: Bourdon, 1979a: 501-503, fig. 21 [Madagascar, infesting Synalpheus sp.]; Bourdon, 1980a: 187, 208-210, fig. 10 [Hong Kong, infesting Synalpheus sp.; Indonesia, infesting Synalpheus sp.; New Caledonia, infesting Synapheus neomeris (de Man, 1897); Queensland, infesting Synalpheus sp.]; Bourdon, 1980b: 243; Kazmi and Bourdon, 1997: 59.

Bopyrella distincta [sic]: Bourdon, 1980a: 210 (not Bopyrella distincta Nierstrasz and Brender à Brandis, 1923).

Parabopyrella indica: Markham, 1982: 345; Markham, 1992a: 298; Kensley, 2001: 224; Kazmi et al., 2002: 61, fig. 18 [Arabian Sea, infesting Synapheus tumidomanus tumidomanus (Paul'son, 1875)]; Poore et al., 2002: 119; Li, 2003: 140, 158; Liu, 2008: 693; Markham, 2010: 152, 162. 
[Parabopyrella] indica: Kazmi and Bourdon, 1997: 59.

Material Examined: None.

Hosts and Localities: Infesting Synapheus neomeris (de Man, 1897), Synapheus nilandensis Coutière, 1905, Synapheus tumidomanus tumidomanus (Paul'son, 1875), Synalpheus $\mathrm{sp}(\mathrm{p})$. (Alpheidae), Pakistan, India, NE of Sri Lanka, Gulf of Manaar, Hong Kong, Red Sea, Arabian Sea, Madagascar, New Caledonia.

REMARKs: Chopra (1923) variously referred to this taxon as a new subspecies or variety of Bopyrella deformans (Hay, 1917) (the type species of Synsynella Hay, 1917), but the name has always been used at the subspecific level.

Parabopyrella perplexa Markham, 1990 Figure 17

Parabopyrella perplexa Markham, 1990: 556559, fig. 2 [Hong Kong, China; infesting "unidentified (caridean?) shrimp"]. - Morton, 2003: 43 (list). - Li, 2003: 140 (list).

Ovobopyrus dentatus An, 2006: 89-90, fig. 42 (unavailable name).

Material Examined: Infesting Alpheus digitalis De Haan, 1844, 1 ㅇ (CIEAL603301), 2 ỡ (CIEAL603302), South China Sea, Stn. $6033, \quad 115^{\circ} 00^{\prime} \mathrm{E}, \quad 22^{\circ} 30^{\prime} \mathrm{N}, 11$ December 1959, coll. Jinzhao Zhu. 1 ㅇ, 1 ๙ (CIEAL920301), Sanya, Hainan Province, $109^{\circ} 30^{\prime} \mathrm{E}, 18^{\circ} 20^{\prime} \mathrm{N}, 23$ March 1992.

Description: Female (CIEAL603301): Length $5.93 \mathrm{~mm}$, maximal width $4.19 \mathrm{~mm}$, head length $1.11 \mathrm{~mm}$, head width $1.54 \mathrm{~mm}$, distorted $26^{\circ}$ (fig. 17A, B).

Head an inverted trapezoid, without frontal lamina, fused with first pereomere on posterior margin; eyes absent (fig. 17A). Antennule of two articles, antenna of four articles, both nonsetose (fig. 17C). Maxilliped triangular with straight palp, fringed with setae on inner margin (fig. 17D, E). Barbula with two pairs of falcate lateral projections on each side and one pair of rounded projections near median (fig. 17F).

Pereomeres distinct; pereon broadest across third pereomere (fig. 17A). Coxal plates and dorsolateral bosses on first three pereomeres on both sides, but larger on longer side. Brood pouch completely open (fig. 17B), oostegite 1 visible in ventral view, second to fourth oostegite small, fifth oostegite longer than others. Oostegite 1 (fig. $17 \mathrm{G}, \mathrm{H}$ ) with two articles nearly equal in length, internal ridge smooth, posterolateral point directed backward, posterior margin setose. Bases of first four pereopods smaller than those of other three pereopods (fig. 17B). Pleon of six pleomeres, first two pleomeres indicated by dorsal sutures and lateral notches, other pleomeres only distinguished by deep lateral notches. Male inserted in median of five pairs of flaplike biramous pleopods (fig. 17B); uropods absent (fig. 17B).

DesCRIPTION: Male (CIEAL603302): Length $1.77 \mathrm{~mm}$, maximal width (across pereomere 3 ) $0.65 \mathrm{~mm}$, head width $0.47 \mathrm{~mm}$, head length $0.16 \mathrm{~mm}$, pleonal length $0.42 \mathrm{~mm}$ (fig. 17I, J). Head elliptical, fusion with first pereomere indicated by lateral notch between head and first pereomere (fig. 17I); eyes absent (fig. 17I). Antennule of three articles, antenna lacking, nonsetose (fig. 17J). Pereomeres subequal in width, without midventral projections (fig. 17J). Dactyli of first three pereopods larger than those of last four pereopods (fig. 17J). Pleon fused and ovate, segments indicated by lateral indentations. Three midventral projections on median of pleon, pleopods and uropods lacking, two clusters of setae on terminal margin of pleon (fig. 17J).

Hosts AND Localities: Infesting Alpheus digitalis De Haan, 1844 (Alpheidae), and unidentified (caridean?) shrimp, Hong Kong and South China Sea.

Remarks: Markham (1990) described this species from Hong Kong, but with the host and male both unknown, so the present records are the first with identified hosts and with males. The present females conform well to the holotype female, with only some minor differences: the lateral plates and dorsolateral bosses of the present specimens are on the first three pereomeres but on the first four pereomeres of the holotype; the posterior margin of oostegite 1 of the present specimens is fringed with setae, but that of the holotype is smooth. 

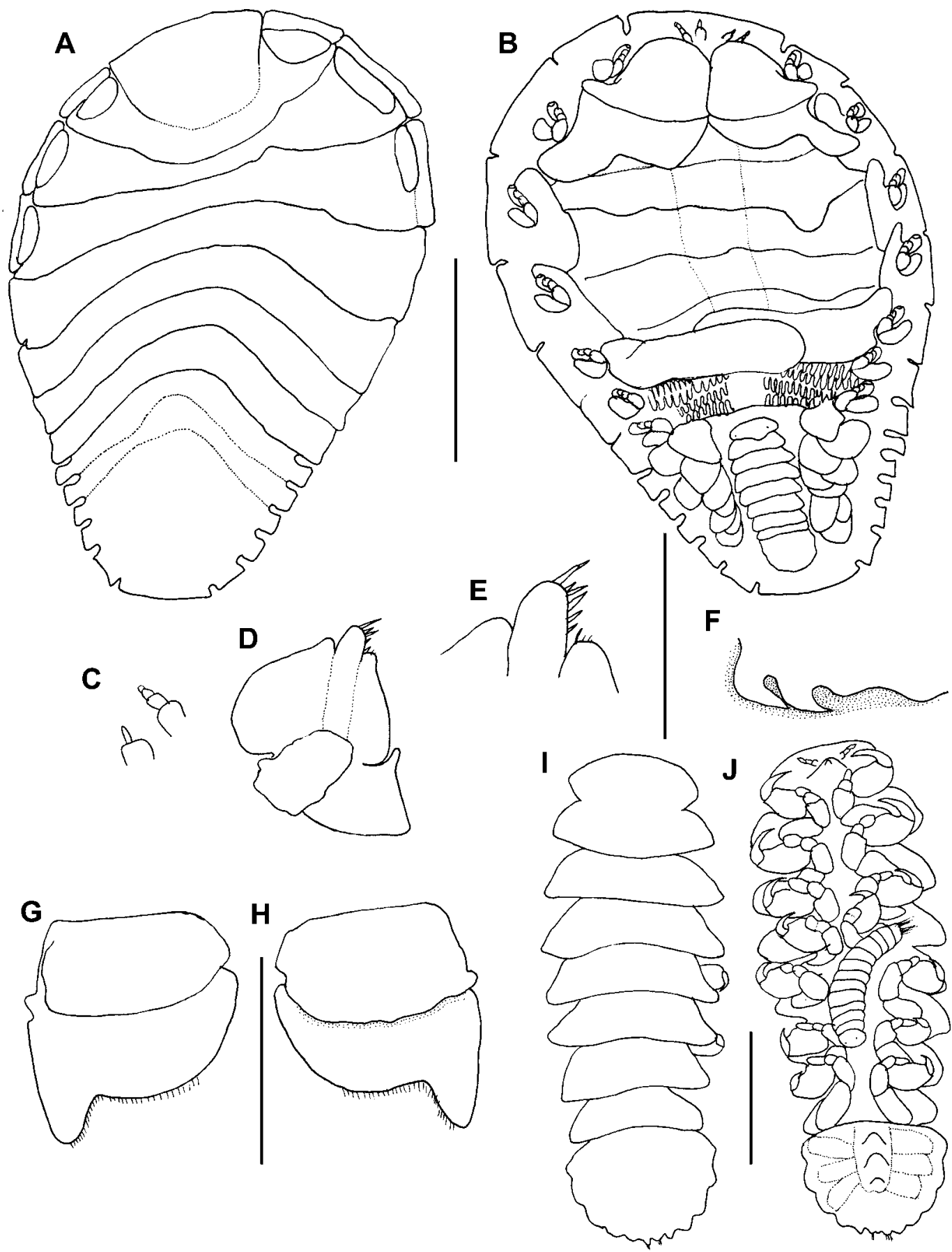

Fig. 17. Parabopyrella perplexa Markham, 1990, reference female (CIEAL603301) (A-H): A. Dorsal view. B. Ventral view. C. Left antennae and antennule. D. Right maxilliped, external view. E. Palp of right maxilliped. F. Right side of barbula. G. Right oostegite 1, external view. H. Right oostegite 1, internal view. Reference male (CIEAL603302) (I, J): I. Dorsal view. J. Ventral view. Scale: 2 mm (A, B); 0.5 mm (C, I, J); $1 \mathrm{~mm}(\mathrm{D}, \mathrm{F}-\mathrm{H}) ; 0.55 \mathrm{~mm}(\mathrm{E})$. 
Parabopyrella symmetros, n. sp. Figure 18

Parabopyrella mortenseni: An, 2006: 84-85, fig. 39 (not Parabopyrella mortenseni Nierstrasz and Brender à Brandis, 1929)).

Material Examined: Infesting Alpheus microstylus (Bate, 1888), holotype o (CIEAL 800505), allotype ô (CIEAL800506), Xisha, Shanhu Islands, $111^{\circ} 40^{\prime} \mathrm{E}, 16^{\circ} 45^{\prime} \mathrm{N}, 9-12$ May 1980. Paratypes: 3 우 (CIEAL800507), 3 đo (CIEAL800508), same data as for holotype.

DesCRIPTION: Holotype female (CIEAL 800505): Length $5.92 \mathrm{~mm}$, maximal width $3.81 \mathrm{~mm}$, head length $1.48 \mathrm{~mm}$, head width $1.55 \mathrm{~mm}$, almost symmetrical (fig. 18A, B). Head an inverted trapezoid, lateral margins distinct, posterior margin fused with first pereomere; black eyes near anterolateral corners (fig. 18A). Antennule of three articles, terminally setose, visible in dorsal view, basal article stout. Antenna of two articles, terminally setose. Maxilliped (fig. 18C) with stout palp, terminally truncate, setose. Barbula (fig. 18D) with two pairs of falcate lateral projections on each side, medially flattened.

Pereon broadest across third pereomere (fig. 18A). Coxal plates and dorsolateral bosses on first four pereomeres. Brood pouch completely open (fig. 18B), oostegite 1 and barbula visible in ventral view. Oostegite 1 (fig. 18E, F) with two articles, anterior margin of first article concave, internal ridge bearing two or three small projections, posterolateral point directed laterally. Pereopods of similar size (fig. 18G), with slender bases and small dactyli. Pleon of six pleomeres, first pleomere distinct, second to fourth pleomeres on right side distinct, but those on left side obscure and only indicated by lateral indentations. Fifth and sixth pleomeres fused and indicated by lateral notches. Pleotelson fan shaped, terminal margin entire. First five pleomeres with flaplike biramous pleopods; uropods absent.

DesCriPTION: Allotype male (CIEAL800 506): Length $1.95 \mathrm{~mm}$, maximal width across pereomere $30.70 \mathrm{~mm}$, head width $0.38 \mathrm{~mm}$, head length $0.17 \mathrm{~mm}$, pleonal length 0.39 $\mathrm{mm}$ (fig. 18H, I). Head elliptical, fused with first pereomere, but with lateral notch between head and pereon (fig. 18H); black eyes mediolaterally (fig. 18H). Antennule of two articles, antenna of three articles, lacking terminal setae (fig. 18I). Pereomeres subequal in width, lacking midventral projections (fig. 18I). Pereopods of similar size, but first two with slightly larger dactyli, last four pereopods with longer carpi than first three (fig. 18I). Pleon with first three segments distinct, last three segments fused but indicated by weak lateral indentations. First three pleomeres with midventral tubercles. Pleopods and uropods lacking (fig. 18I).

EтYMOLOGY: The specific name symmetros is feminine and refers to the female having an almost symmetrical body shape.

Hosts AND Locality: Infesting Alpheus microstylus (Bate, 1888) (Alpheidae), Xisha (Paracel Islands), China.

Remarks: Parabopyrella symmetros, n. sp., belongs to the "A" group with the female pleotelson posterior margin entire, not incised or indented. The new species can be distinguished from the other five species of "A" group by the symmetrical female having the first, second, and third pleomeres on the right side distinct, and the male with the first three pleomeres distinct. This species is most closely related to $P$. perplexa, but $P$. perplexa females have an asymmetrical body, lack eyes, have the posterolateral point of oostegite 1 acute, and the palp of the maxilliped triangular. Alpheus microstylus is also known to be infested by Bopyrione toloensis Markham, 1982.

\section{KEY TO THE 28 SPECIES OF \\ PARABOPYRELLA MARKHAM, 1985, BASED ON MALE AND FEMALE CHARACTERS}

1a. Posterior edge of female pleotelson entire .. 2

1b. Posterior edge of female pleotelson not entire ............... 15

2a. Posterior edge of female pleotelson truncate or very weakly convex ........ 3

2b. Posterior edge of female pleotelson strongly convex ............. 4

3a. Body symmetrical .... P. symmetros, n. sp.

3b. Body asymmetrical . . . . . . . . . . .

P. perplexa Markham, 1990

4a. Posterior edge of female pleotelson rounded .. 8

4b. Posterior edge of female pleotelson not rounded ............... 5 

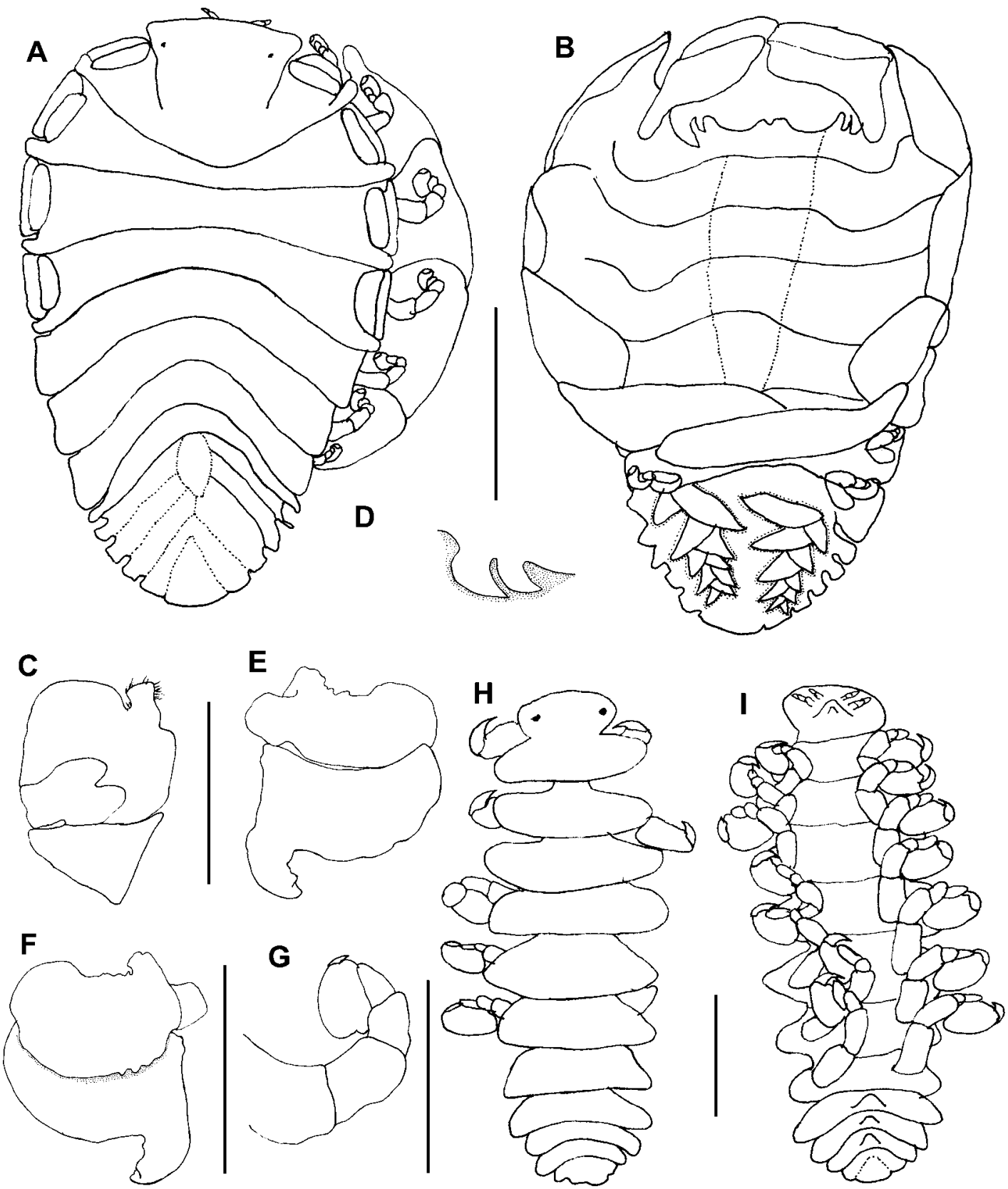

Fig. 18. Parabopyrella symmetros n. sp., holotype female (CIEAL800505) (A-G): A. Dorsal view. B. Ventral view. C. Right maxilliped, external view. D. Right side of barbula. E. Right oostegite 1, external view. F. Right oostegite 1, internal view. G. Right pereopod 7. Allotype male (CIEAL800506) (H, I): H. Dorsal view. I. Ventral view. Scale: $2 \mathrm{~mm}$ (A, B); $1 \mathrm{~mm}$ (C, D); $1.5 \mathrm{~mm}$ (E, F); $0.55 \mathrm{~mm}(\mathrm{G}) ; 0.5 \mathrm{~mm}$ (H, I). 
5a. Anterior margin of female head crenulated .......... crenulata (Shiino, 1939)

5b. Anterior margin of female head smooth .. 6

6a. Dorsolateral bosses reduced on both sides of female pereon . . . . . . . . . choprai

(Nierstrasz and Brender à Brandis, 1929)

6b. Dorsolateral bosses on at least one side of female's first four pereomeres ....... 7

7a. Distal margin of female pleotelson acute ........ P. delagoae (Bourdon, 1982)

7b. Distal margin of female pleotelson blunt ........ P. angulosa (Bourdon, 1980a)

8a. Coxal plates and dorsolateral bosses of female absent ... P. setoensis (Shiino, 1939)

8b. Coxal plates and dorsolateral bosses of female present ............ 9

9a. Lateral margin of pleon of male deeply indented ............... 10

9b. Lateral margin of pleon of male slightly indented ............... 12

10a. Median of female pleon fused, segments obscure . . . . . . . P. angusta (Shiino, 1963)

10b. Median of female pleon not fused, only last two pleomeres fused . . . . . . . . . 11

11a. Male with five pairs of pleopods. . . . . . . ........ P. nierstraszi (Chopra, 1930)

11b. Male with four pairs of pleopods . . . . . . ......... P. tanyensis (Bourdon, 1979)

12a. Female barbula with one pair of lateral projections .......... saronae

(Bourdon and Bruce, 1979)

12b. Female barbula with two pairs of lateral projections ............. 13

13a. First oostegite with long posterior portion ... P. essingtoni (Bourdon and Bruce 1983)

13b. Oostegite 1 with short posterior portion . . 14

14a. Pleon of male much broader than pereon ....... P. richardsonae (Nierstrasz and

Brender à Brandis, 1929)

14b. Pereon of male equal to or broader than pleon ..... P. mortenseni (Nierstrasz and

Brender à Brandis, 1929)

15a. Distal edge of female pleon deeply separated ............... 16

15b. Distal edge of female pleon slightly indented ............... 17

16a. Pereon of female much wider than pleon ........ P. lata (Nierstrasz and

Brender à Brandis, 1929)

16b. Pereon of female equal to or slightly wider than than pleon ........ P. megatelson (Nierstrasz and Brender à Brandis, 1929) 17a. Divergent pleotelson of female terminally rounded ............... 18

17b. Divergent pleotelson of female not terminally rounded . . . . . . . . . . 20

18a. Male with slender pleon, all segments fused, without lateral indentations . . . . . P. thomasi (Nierstrasz and Brender à Brandis, 1929)

18b. Male with broad pleon, lateral indentations indicating segments . . . . . . . . . 19

19a. Barbula of female with one pair of lateral projections .... P. intermedia (Nierstrasz and Brender à Brandis, 1923)

19b. Barbula of female with two pairs of lateral projections .... P. distincta (Nierstrasz and Brender à Brandis, 1923)

20a. Pleotelson of female divergent and terminally quadrate .............. 21

20b. Pleotelson of female slightly divergent, ter-

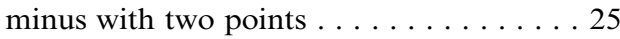

21a. Male with uropods ............. ........... P. pacifica (Shiino, 1933)

21b. Male without uropods . . . . . . . . . 22

22a. Male pleomeres not completely fused . . 23

22b. Male pleon fused, segments indicated only by lateral indentations . . . . . . . . . . . . 24

23a. Male pleon segments indicated by dorsal obscure sutures and deep lateral indentations ........ P. barnardi (Nierstrasz and Brender à Brandis, 1931)

23b. Male pleon segments without any fusion, distinct ......... P. cuspidata, n. sp.

24a. Female with eyes . . . . . . . . . . . . . P. elongata (Shiino, 1949)

24b. Female without eyes . . . . . . . . . . . . . . . . . P. australiensis (Bourdon, 1980a)

25a. Pleomeres of male fused, with very weak lateral indentations . . . . . . . . . 26

25b. Pleomeres of male fused only medially . . . 27

26a. Male first two pleomeres with midventral tubercles ..... P. bonnieri (Nierstrasz and Brender à Brandis, 1923)

26b. Male first pleomere only with midventral tubercle ....... P. incisa (Chopra, 1923)

27a. Male first two pleomeres much wider than pleon ....... P. hodgarti (Chopra, 1923)

27b. Male first pleomere only wider than pleon ...... P. indica (Chopra, 1923)

\section{Probopyriscus Markham, 1982}

Diagnosis (modified from Markham, 1982): Female: Body approximately half as long as 
wide, slightly distorted; head distinct and extended anteriorly, with long frontal lamina; maxilliped palp extended and articulated with large spur; barbula with single blunt projection on each side with trace of second projection mesially; all pereomeres distinct with coxal plates covering margins; oostegites reduced and exposing brood pouch, oostegite 1 slightly pointed and internally unadorned; pleon of six distinct pleomeres well separated laterally; five pairs of flaplike biramous pleopods; no uropods.

Male: Head distinctly separated laterally from first pleomere; all pereomeres distinct and separated by lateral notches; pereopods small, all equally developed, with meri and carpi fused; pleon of six pleomeres indistinctly separated dorsally but deeply separated laterally; five pairs of buttonlike pleopods; no uropods.

TYPE SPECIES: Probopyriscus novempalensis Markham, 1982, by original designation.

Other Species: None.

REMARKs: Markham (1982) compared the characters of the type and sole species of Probopyriscus with those of several other bopyrines, including the western Atlantic Parabopyriscus stellatus and he indicated that the diagnosis of the latter genus and species was in press; that paper was eventually published as Markham (1985a). By introducing Parabopyriscus stellatus as a genus and species combination with detailed morphological characters that clearly differentiated these taxa from all others, Markham (1982, not 1985a) made these names available (ICZN, 1999: Article 13) and, as there was only a single species stated to be in Parabopyriscus, $P$. stellatus is the type species by monotypy.

\section{Probopyriscus novempalensis Markham, 1982}

Probopyriscus novempalensis Markham, 1982: 293-296, fig. 1 [Hong Kong, infesting Alpheus sp.]; Li, 2003: 140, 158.

Material Examined: None.

Hosts and Localities: Infesting Alpheus sp. (Alpheidae), Hong Kong.

REMARKs: This species is known only from the holotype and allotype pair.

\section{Septembopyrina, n. gen.}

Diagnosis: Female: Body slightly distorted, pleomeres distinct. Head fused with first pereomere medially and with well-developed frontal lamina, boundary with head obscure. Maxilliped without palp, barbula with pair of projections. Dorsolateral bosses only on first pereomere. Seven pairs of oostegites, brood pouch widely open. Oostegite 1 of left side and right side slightly different in shape, internal ridges smooth. Seventh oostegite smallest. Pleon of five pleomeres, final one very broad. Five pairs of uniramous flaplike pleopods, uropods lacking.

Male: Body width about 1/3 length. Head fused with first pereomere, lateral indentations present. No midventral tubercles. Pereopods smaller posteriorly. Pleon segments distinct ventrally but fused dorsally.

Etymology: The prefix "septem" (for the seven oostegites of the female) plus the genric name Bopyrina are selected to emphasize the close relationship to Bopyrina; gender feminine.

TyPe SPECIES: Septembopyrina tozeumaophila, n. sp., by original designation.

OTHER SPECIEs: None.

Remarks: The new genus is related to Schizobopyrina Markham, 1985, and Bopyrina in that all have unequal formation of oostegite 1 , head somewhat fused with the first pereomere, uniramous pleopods and lack uropods. Markham (1985a) separated Schizobopyrina from Bopyrina and transferred 10 species from Bopyrina to Schizobopyrina. He showed that Schizobopyrina females have a maxilliped palp, elongate oostegites $2-5$, and at least lateral separation of the pleomeres, but Bopyrina females lack a maxilliped palp, have tiny oostegites 2-5, and pleomere fusion on the shorter side. This new genus is most closely related to Bopyrina, but Septembopyrina, $\mathrm{n}$. gen., has the female pleomeres distinct on both sides and seven pairs of oostegites. The new genus also can be distinguished from Schizobopyrina by the weakly asymmetrical body (strongly asymmetrical in Schizobopyrina), five pairs of uniramous pleopods (four pairs in Schizobopyrina), and maxilliped without palp (with palp in Schizobopyrina). The presence of seven pairs of oostegites is very uncommon and considered a primitive 
character state in bopyrids (Boyko and Williams, 2010); the only prior records from any bopyrines are from Bopyrinella albida and Capitetragonia elliptica, but the type species of Septembopyrina, n. gen., does not otherwise resemble these two species except in this one character.

\section{Septembopyrina tozeumaophila, $\mathrm{n}$. sp.} Figure 19

Parabopyrina tozeumaus An, 2006: 74-75, fig. 32 (unavailable name).

MATERIAl ExAmined: Infesting Tozeuma lanceolatum Stimpson, 1860, holotype 우 (CIEHI790502a), allotype ot (CIEHI790502b), Beibu Gulf, Stn. $7905,108^{\circ} 30^{\prime} \mathrm{E}, 18^{\circ} 30^{\prime} \mathrm{N}$, 29 m, 6 January 1962, coll. Fuzeng Sun. Paratypes: 1 ㅇ, 2 ơ (CIEHI620301), South China Sea, Stn. 6203, $109^{\circ} 00^{\prime} \mathrm{E}, 18^{\circ} 15^{\prime} \mathrm{N}, 23.8 \mathrm{~m}$, 16 July 1959, coll. Fengshan Xu. Other material: 2 우, 1 ๙ (CIEHI790501), Beibu Gulf, Stn. 7905, $108^{\circ} 30^{\prime} \mathrm{E}, 18^{\circ} 30^{\prime} \mathrm{N}, 26 \mathrm{~m}, 16$ August 1962, coll. Fuzeng Sun; 2 우우 (CIEHI405401), East China Sea, Stn. 4054, $123^{\circ} 30^{\prime} \mathrm{E}, 29^{\circ} 30^{\prime} \mathrm{N}, 69 \mathrm{~m}, 8$ December 1959 , coll. Yongliang Wang and Jinzou Zhu; 1 우 (CIEHI590201), East China Sea, Stn. 4054, $123^{\circ} 30^{\prime} \mathrm{E}, 29^{\circ} 30^{\prime} \mathrm{N}, 86 \mathrm{~m}, 1$ February 1959 ,

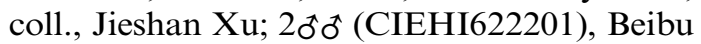
Gulf, Stn. 6222, $108^{\circ} 30^{\prime} \mathrm{E}, 18^{\circ} 45^{\prime} \mathrm{N}, 23 \mathrm{~m}, 26$ January 1959, coll. Zhengang Fan; 1 ㅇ (CIEHI606601), South China Sea, Stn. 6066, $113^{\circ} 30^{\prime} \mathrm{E}, 20^{\circ} 30^{\prime} \mathrm{N}, 88 \mathrm{~m}, 9$ April 1960, coll. Zhican Tang; 2 우 (CIEHI405402), East China Sea, Stn. 4054, $123^{\circ} 30^{\prime} \mathrm{E}, 2^{\circ} 30^{\prime} \mathrm{N}, 75$ m, 7 April 1959, coll. Yulin Liao and Mingshou Li.

DesCRIPTION: Holotype female (CIEHI790 502a): Length $4.41 \mathrm{~mm}$, maximal width 2.94 $\mathrm{mm}$, head length $0.76 \mathrm{~mm}$, head width 1.24 mm, slightly distorted (fig. 19A, B).

Head an inverted trapezoid, lateral margin distinct, posterior margin fused and embedded in first pereomere. Head with large frontal lamina, boundary between head and frontal lamina obscure; without eyes (fig. 19A). Antennule and antenna of two and three articles, respectively, terminally without setae (fig. 19C). Maxilliped (fig. 19D) without palp, first article cube shaped, short and with blunt spur. Barbula (fig. 19E) with pair of falcate lateral projections on each side and pair of triangular tubercles medially.

Pereon broadest across third and fourth pereomeres (fig. 19A). Dorsolateral bosses only on first pereomeres (fig. 19A). Brood pouch widely open (fig. 19B), with seven pairs of oostegites. Oostegite 1 of left side and right side asymmetrical: oostegite 1 of left side (fig. $19 \mathrm{~F}, \mathrm{G})$ with broad posterolateral point, of right side (fig. $15 \mathrm{H}, \mathrm{I}$ ) with trianglar posterolateral point. Oostegite 1 with smooth internal ridge; oostegites 2, 3 larger than others, oostegite 7 smallest. Pereopods of similar size and structure (fig. 19J, K). Pleon of five pleomeres, first four narrow with obscure sutures. Fifth pleomeres broad and terminally extended into two small tubercles. Five pairs of uniramous flaplike pleopods, uropods lacking (fig. 19B).

DESCRIPTION: Allotype male (CIEHI790 502b): Length $1.50 \mathrm{~mm}$, maximal width (across pereomere 2) $0.45 \mathrm{~mm}$, head width $0.31 \mathrm{~mm}$, head length $0.17 \mathrm{~mm}$, pereon length $0.95 \mathrm{~mm}$ (fig. 19L, M). Head elliptical, fused with first pereomere but separated by lateral notch between head and pereon (fig. 19L). Black eyes in lateral corners (fig. 19L). Antennule of two articles, antenna of three articles, terminally nonsetose. Pereomeres distinct, lacking midventral projections (fig. 19M). Pereopods with similar structure, but posteriorly smaller (fig. 19M). Pleon with first three segments distinct, last three segments fused but indicated by lateral indentations and ventral sutures. Pleopods and uropods lacking (fig. 19I).

VARIATION: One female from CIEHI790501 is different from the other female specimen in the lot as well as all other material as it has very reduced oostegites.

Etymology: The specific name tozeumaophila refers to the generic name of the host shrimp.

Host And Localities: Infesting Tozeuma lanceolatum Stimpson, 1860 (Hippolytidae), Beibu Gulf, South China Sea, East China Sea, 23-88 m.

REMARKs: The present specimens represent a new genus and species related to Bopyrina and Schizobopyrina. Tozeuma lanceolatum is first recorded here as a host for parasitic isopods. Other species of bopyrids known to 

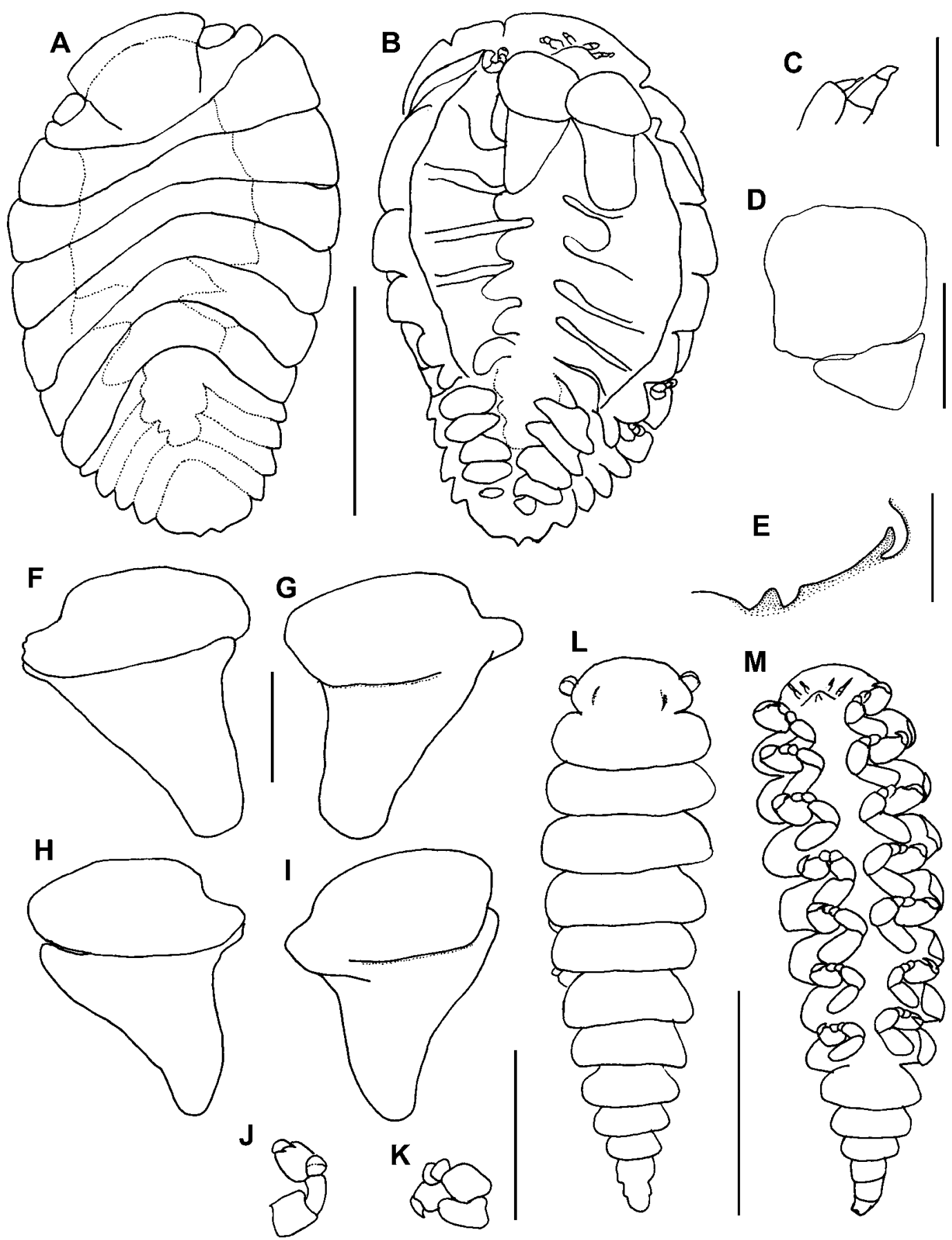

Fig. 19. Septembopyrina tozeumaophila n. sp., holotype female (CIEHI790502a) (A-K): A. Dorsal view. B. Ventral view. C. Right antenna and antennule. D. Right maxilliped, external view. E. Right side of barbula. F. Right oostegite 1, external view. G. Right oostegite 1, internal view. H. Left oostegite 1, external view. I. Left oostegite 1, internal view. J. Right pereopod 1. K. Right pereopod 7. Allotype male (CIEHI790502b) (L, M): L. Dorsal view. M. Ventral view. Scale: $2 \mathrm{~mm}$ (A, B); $0.25 \mathrm{~mm}$ (C); $0.5 \mathrm{~mm}$ (D$\mathrm{K}) ; 0.6 \mathrm{~mm}(\mathrm{~L}, \mathrm{M})$. 
parasitize Tozeuma hosts are Parabopyrella thomasi (Nierstrasz and Brender à Brandis, 1929) (infesting T. carolinense Kingsley, 1878, in St. Thomas) and Schizobopyrina lobata (Bourdon and Bruce, 1983) (infesting Tozeuma sp. in Queensland, Australia).

Hemiarthrinae Markham, 1972

Diagnosis: Female: Body highly distorted. Head deeply embedded into pereon. Pereomeres only distinct on short side. Brood pouch closed, covering entire ventral and lateral side of body. Seven pairs of pereopods usually present on short side. Pleomeres with variable degree of fusion, first four pairs of pleopods with lateral plates. Uropods present.

Male: Pereon segments distinct, without midventral tubercles. Pleon fused, without any pleopods or uropods.

Remarks: Most of the 55 species, in 27 genera, placed in Hemiarthrinae are ventral abdominal parasites of caridean shrimps (although a few species infest caridean hosts dorsoventrally or in the region of the mouthparts). Previously, only five species from Chinese waters were reported, all from Hong Kong (Markham, 1982; 1990).

\section{Anchiarthrus Markham, 1992}

Diagnosis (modified from Markham, 1992a): Female: Body distorted less than $90^{\circ}$; head lacking antennal groove; barbula with single projection on each side. First and second pereopods of long side large, others small; first and second pereopods on short side absent others small and clustered near pleon. Oostegite 1 dimorphic, smaller one much longer than wide. Pleonal separation indistinct with three pleomeres indicated; three pairs of lanceolate lateral plates, progressively smaller posteriorly; three pairs of biramous pleopods, progressively larger posteriorly.

Male: Body slightly more than twice as long as broad. Head distinct from pereon; antennae prominently extended beyond margin of head. Last pereomere fused with pleon, remnants of pleomeres indicated laterally.

TYPE SPECIES: Anchiarthrus derelictus Markham, 1992, by original designation.

\section{OTHER Species: None.}

Anchiarthrus derelictus Markham, 1992

Anisarthrus (?), sp. nov. Markham, 1990: 555, 564.

Anchiarthrus derelictus Markham, 1992a: 296-297, fig. 17.

Material Examined: None.

Hosts AND Localities: Infesting Arete dorsalis Stimpson, 1860 (Alpheidae), Hong Kong, $1 \mathrm{~m}$.

Remarks: As noted by Markham (1990, 1992a), Anchiarthrus derelictus is most similar to Anisarthrus pelseneeri Giard, 1907 (the type species of Anisarthrus Giard, 1907; see Giard, 1907), but differs from it in the female having two large pereopods, fewer than seven pereopods on the shorter side of the body, and three distinguishable pleomeres.

\section{Apophrixus Nierstrasz and Brender à Brandis, 1931}

Diagnosis: (modified from Nierstrasz and Brender à Brandis, 1931, Markham, 1982): Female: Body weakly asymmetrical, one side more swollen and longer than other. Head large. Dorsal side with four distinct pereomeres; pleomeres fused. Seven pereopods on short side of body, 6 or 7 on long side; pereopods 4-6 smaller than others. Pleon with four pairs of well-developed lateral plates and four pairs of uniramous pleopods; uropods uniramous.

Males: Pleomeres fused into single large segment, no pleopods or uropods.

TYPE SPECIES: Apophrixus philippinensis Nierstrasz and Brender à Brandis, 1931, by monotypy.

OTHER SPECIES: Apophrixus constrictus Markham, 1982.

Apophrixus constrictus Markham, 1982

Apophrixus constrictus Markham, 1982: 378381, fig. 30-31.

Material Examined: None.

Hosts and Localities: Infesting Alpheus sp. (Alpheidae), Hong Kong. 


\section{Dicropleon Markham, 1972}

Diagnosis (modified from Markham, 1972): Female: Body weakly asymmetrical; head deeply embedded in pleon. First two pereopods on long side well developed, third pereopod present but much smaller, other pereopods lacking. Pleon with four pairs of well developed lateral plates and four pairs of pleopods, first three biramous; fifth pleomere divided into two large terminal lobes, uropods lacking.

Male: Head and pleon medially fused with pereon; eyes present, antennae elongate. Pleon ending in sharp double point.

TyPe SPECIES: Dicropleon periclimenis Markham, 1972, by original designation.

Other Species: Dicropleon bifidus (Bourdon, 1967), D. morator Markham, 1982, D. processae Markham, 1980.

\section{Dicropleon morator Markham, 1982}

Dicropleon morator Markham, 1982: 381-384, figs. 32-33 [Hong Kong, infesting Periclimenis commensalis Borradaile, 1915]; Bruce, 1982: 237 (species erroneously cited as described in "Markham, 1981" (lapsus for 1982)); Li, 2003: 153, 157.

Material Examined: None.

Hosts and Localities: Infesting Periclimenis commensalis Borradaile, 1915) (Palaemonidae), Hong Kong.

REMARKs: Although the mention of the species by Bruce (1982) occurred on an earlier page in the same volume in which Markham (1982) described the species, it is technically not a nomen nudum as Bruce (1982) was published at the same time as Markham (1982) and there is no page priority rule in the International Code of Zoological Nomenclature.

\section{Eophrixus Caroli, 1930}

Diagnosis: Female: Body distorted with swollen brood pouch. All seven pairs of pereopods well developed and of same size. Pleon of five segments, first four pleomeres with lobate lateral plates and biramous pleopods. Endopodite of pleopods often smaller than exopodites; uropods usually small.
Male: Longer than wide, head often fused with first pereomere. Pleon fused into single piece, without pleopods.

Type SPecies: Phrixus (Eophrixus) lysmatae Caroli, 1930, by subsequent designation of Markham, 1982.

OTHER SPECIES: Eophrixus adriaticus (Nierstrasz and Brender à Brandis, 1931), E. brevicauda (Chopra, 1923) n. comb., E. caudatus, n. sp., E. enchophyllus Caroli, 1930, E. kuboi (Shiino, 1939), E. laevimanus Caroli, 1930, E. leptochelae (Pillai, 1966) n. comb., E. nigrocinctus (Chopra, 1923), E. pikei (Bruce, 1968), n. comb., E. shojii Shiino, 1941, E. subcaudalis (Hay, 1917).

Remarks: Caroli (1930) established Eophrixus, containing three species, as a subgenus of "Phrixus" (= Hemiarthrus Giard and Bonnier, 1887), but only one species, Phrixus (Eophrixus) lysmatae Caroli, 1930, was well described, leading Markham (1985a) to conclude that the other two species, Phrixus (Eophrixus) enchophyllus Caroli, 1930, and Phrixus (Eophrixus) laevimanus Caroli, 1930, were nomina nuda. However, Caroli (1930) mentioned morphological characters (mostly color) and provided photographs (of poor quality) for both these species therefore, although both are poorly described and not included in the key below, the names are available under ICZN Article 12.2.7 (applying to names published before 1931). The earliest author to mention a type species for the genus appears to be Markham (1982), but he indicated that Phrixus (Eophrixus) lysmatae was the type species by monotypy, which is incorrect. Markham (1982) actually selected Phrixus (Eophrixus) lysmatae as the type species of Eophrixus by subsequent designation. Nierstrasz and Brender à Brandis (1931) raised Eophrixus to generic status and Caroli (1949) synonymized Hypophryxus Shiino, 1934, with Eophrixus.

Markham (1992a) purportedly removed Hypophryxus from synonymy with Eophrixus, but a reading of that paper shows that he was, in fact, purporting to remove from synonymy Hyperphrixus, a genus that has never been synonymized with any other. Markham (1992a) appeared to transfer Hemiarthrus filiformis Chopra, 1923, to Hypophryxus (e.g., pp. 277, 291 and fig. 15, 16 figure captions 
on pp. 292-293) but also on (pp. 292-293) gave the new combination as Hyperphryxus [sic] filiformis and erroneously referred to Hyperphrxus [sic] Shiino, 1934, when Hyperphrixus was a genus erected by Nierstrasz and Brender à Brandis, 1931. He also cited the type species of Hyperphrixus as Hyperphryxus [sic] yusakiensis Shiino, 1934, when it is Hyperphrixus tattersalli Nierstrasz and Brender à Brandis, 1931. Apparently, Markham (1992a) became confused by the similarity of the genus names Hyperphryxus and Hypophrixus and confounded their characters and type species. Based on the key characters of $H$. filiformis, including having fewer than seven pereopods on one side of the body, this species belongs to Hyperphrixus, not Hypophryxus. The correct name for the species is therefore Hyperphrixus filiformis (Chopra, 1923) (new combination). Markham's (1992a) statement about removing Hyperphryxus [sic] from synonymy with Eophrixus is likewise incorrect as Hyperphrixus was never synonymized with Eophrixus by Caroli (1949) or any other author. Hypophryxus was synonymized with Eophrixus by Caroli (1949) bases on the fact that the type species (H. yusakiensis) has all the characters of Eophrixus and thus we concur that the two genera should be considered synonymous. Pillai (1966) and Bruce (1968) each described a species in Hypophryxus, both unaware of Caroli's (1949) synonymy of that genus with Eophrixus. The result of this is that Eophrixus contains 13 species: the seven included by Markham (1985a), the two poorly described species of Caroli (1930), Hemiarthrus brevicauda Chopra, 1923, Hypophryxus leptochelae Pillai, 1966, Hypophryxus pikei Bruce, 1968, and the new species described herein.

\section{Eophrixus brevicauda (Chopra, 1923), n. comb.}

? "Parasite" de Man, 1913: 263.

Hemiarthrus brevicauda Chopra, 1923: 416, 419, 430, 431, 439-440, pl. 11, figs. 8-9. Monod, 1933: 244.

Phrixus (Paraphrixus) brevicauda: Caroli, 1930: 259.

Paraphrixus brevicauda: Nierstrasz and Brender a Brandis, 1931: 205. - Markham, 1992a: table 1.
? Paraphrixus brevicauda: Markham, 1990: 563-564.

\section{Material Examined: None.}

Hosts and Localities: Infesting Synalpheus hastilicrassus Coutière, 1905, S. tumidomanus tumidomanus (Paul'son, 1875) (Alpheidae), Indonesia (?), Andaman Islands, Hong Kong, 2-9 fathoms (= 3.7-16.5 m).

Remarks: Markham (1985a) transferred the type species of Paraphrixus, Phryxus subcaudalis Hay, 1917, to Eophrixus, synonymizing the two genera. However, Markham (1990, 1992a) continued to use the combination Paraphrixus brevicauda while admitting (1990) that "Paraphrixus is no longer a valid name, but revision of the genus is not appropriate here." It is clear that, based on current data, Hemiarthrus brevicauda must be placed in Eophrixus, as this is the genus with which it shares the most characters and, as a synonymized genus, it cannot be used as a valid name. Rediscovery of E. brevicauda is desirable in order to determine whether it really belongs in Eophrixus, as Chopra's (1923) description is incomplete and the type specimens are inaccessible.

Eophrixus caudatus, n. sp.

Figures 20, 21A, B

Eophrixus shojii An, 2006: 172-173, fig. 88 (not Eophrixus shojii Shiino, 1941).

Material Examined: Infesting Alpheus microstylus (Bate, 1888) (fig. 17A, B), holotype $ᄋ$ (CIEAL800501), allotype o (CIEAL 800502): Xisha Coral Island, $16^{\circ} 32^{\prime} \mathrm{N}$, $111^{\circ} 36^{\prime} \mathrm{E}, 9-21$ May 1980.

DESCRIPTION: Holotype female (CIEAL 800501): Length $6.11 \mathrm{~mm}$, including lateral plates, maximal width $4.43 \mathrm{~mm}$, including brood pouch, head length $0.56 \mathrm{~mm}$, head width $1.56 \mathrm{~mm}$ (figs. 20A, 21A, B).

Body strongly asymmetrical, with swollen pereon. Head inserted into pereon, with bilobate anterior and posterior margins, without eyes (fig. 20A). Antennule of three articles, antenna of four articles, both setose, with stout bases (fig. 20C). Maxilliped rectangular, without palp, plectron blunt, anterior article 3 times larger than posterior article (fig. 20D). 


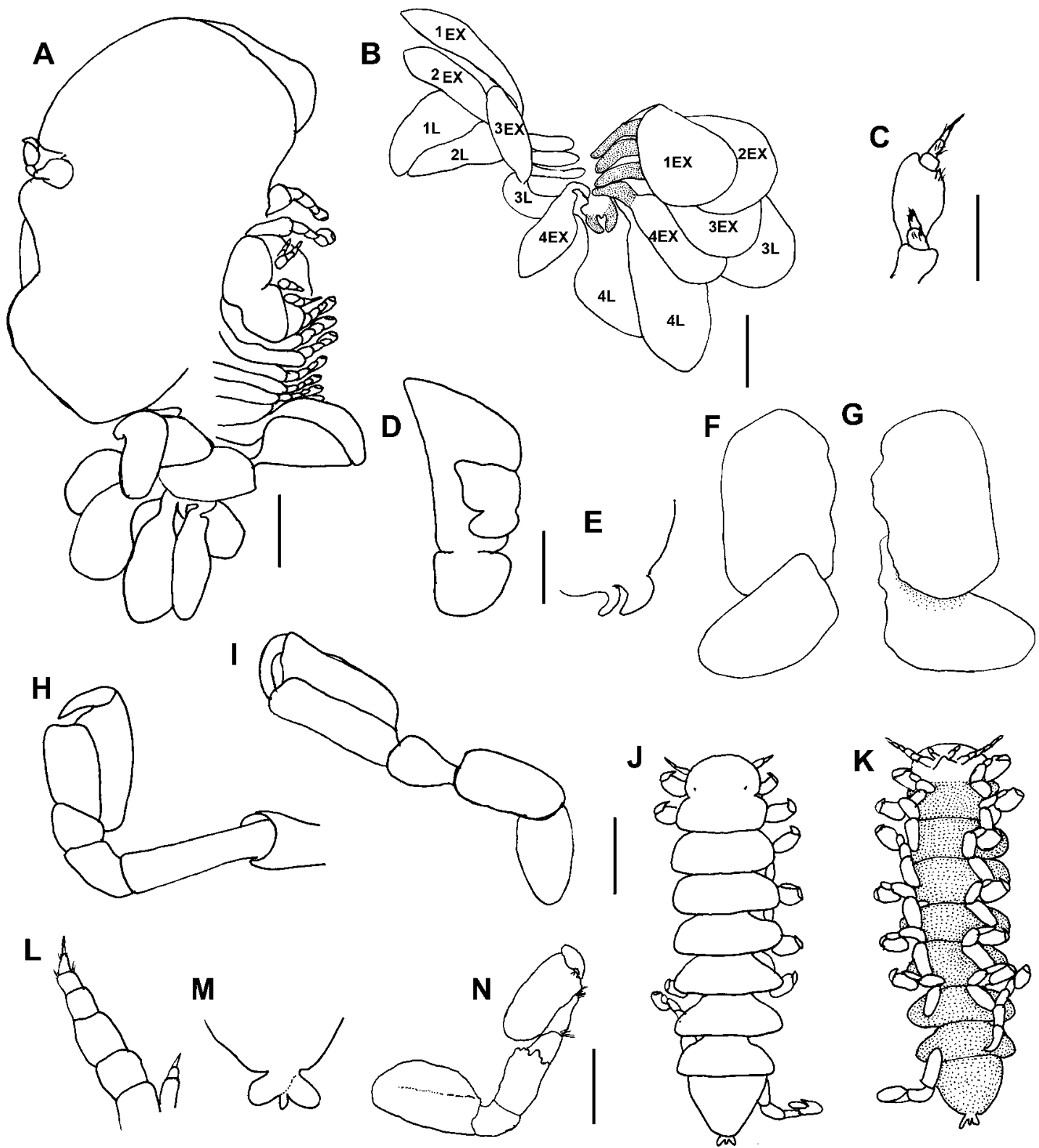

Fig. 20. Eophrixus caudatus, n. sp., holotype female (CIEAL800501) (A-G): A. Dorsal view. B. Ventral view of pleon. C. Left antenna and antennule. D. Left maxilliped. E. Barbula of right side. F. Right oostegite 1, external view. G. Right oostegite 1, internal view. H. Left pereopod 5. I. Left pereopod 6. Allotype male (CIEAL800502) (J-N): J. Dorsal view. K. Ventral view. L. Right antenna and antennule. M. Ventral view of pleon. N. Right pereopod 7. Scale: $1 \mathrm{~mm}$ (A); $0.6 \mathrm{~mm}$ (B, E-G, J, K); $0.45 \mathrm{~mm}$ (D); $0.2 \mathrm{~mm}$ $(\mathrm{C}, \mathrm{N}) ; 0.15 \mathrm{~mm}(\mathrm{H}, \mathrm{I}, \mathrm{L}, \mathrm{M})$.

Barbula with two pairs of simple falcate lateral projections on each side (fig. 20E).

Left side of body somewhat fused, but right side distinctly segmented with pereopods closely crowded together. Dorsolateral bosses and coxal plates absent. Swollen brood pouch completely closed (fig. 20A). Oostegite 1 (fig. $20 \mathrm{~F}$, G) with smooth internal ridge, 


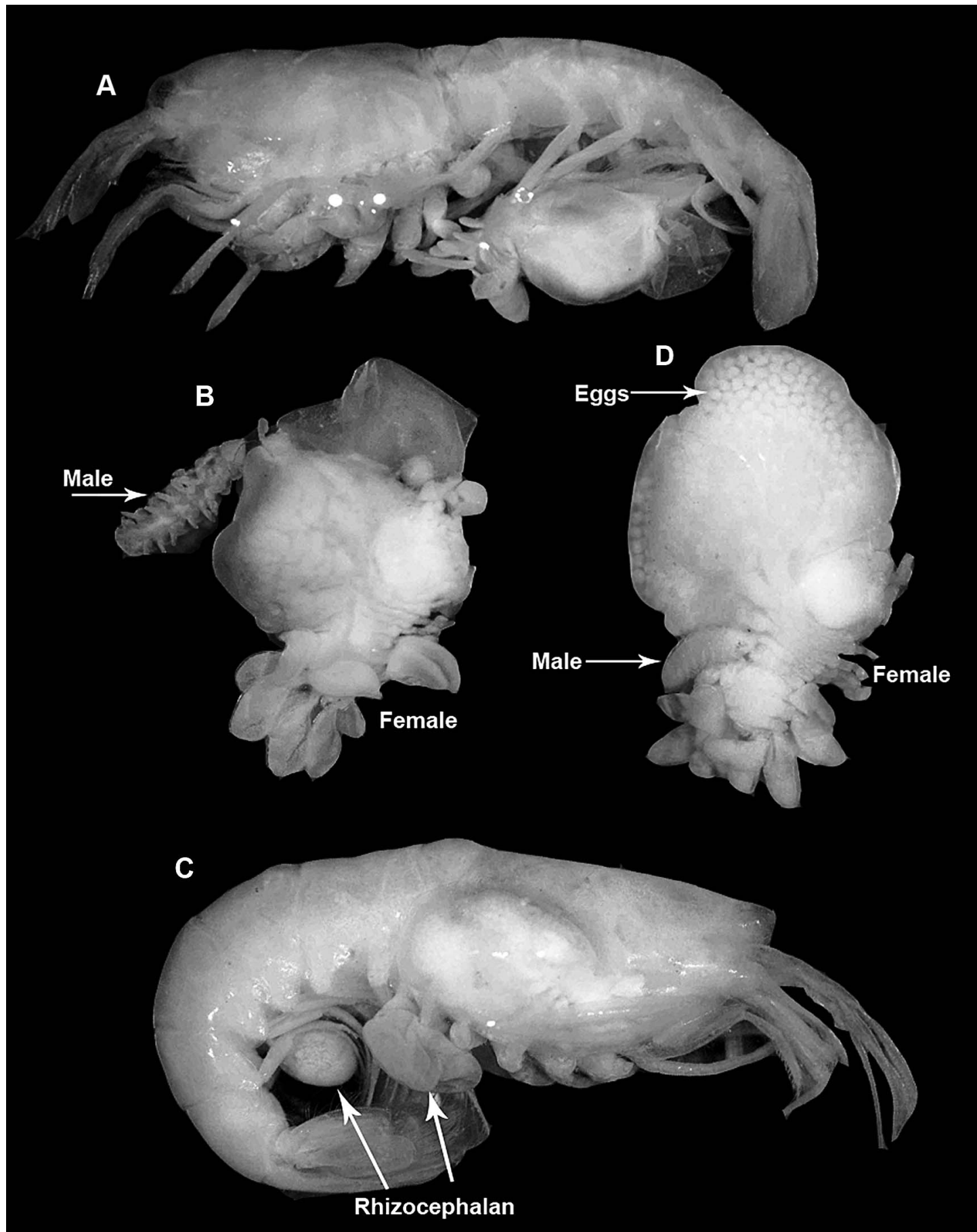

Fig. 21. Hemiarthrine bopyrids and hosts. A. Host of Eophrixus caudatus, n. sp. B. Female, male and eggs of E. caudatus. C. Host of Sigyn branchialis, n. gen., n. sp. (right branchial chamber bulge indicating bopyrid, arrows indicating rhizocephalans). D. Dorsal view of female of S. branchialis, n. gen., n. sp. with attached male. 
posterolateral point rounded and directed laterally. Seven pereopods crowded together on short side, but first two pereopods on long side near head, third pereopod inserted in brood pouch, last four pereopods crowded between brood pouch and lateral plates. All pereopods slender, with long meri, dactyli longer in posterior pereopods (fig. 20H, I). Pleon with four pairs of lateral plates and biramous pleopods, segmentation indistinct. All lateral plates and exopodites of pleopods lobate, endopodites well developed (fig. 20B). Terminal pleomere with distinct uniramous uropods (fig. 20B).

DescriPtion: Allotype male (CIEAL8 00502): Length $3.53 \mathrm{~mm}$, maximal width (across pleon 4) $0.93 \mathrm{~mm}$, head width 0.67 $\mathrm{mm}$, head length $0.33 \mathrm{~mm}$ (fig. 20J, K). Head semicircular (fig. 20J), fused with first pereomere; small black eyes posterolaterally (fig. 20J). Antennule of three articles, almost smooth, antenna of six articles, terminal two articles setose (fig. 20L). All pereomeres subequal in width, lacking midventral projections (fig. 20K). All pereopods of same size and structure, carpi and meri terminally setose, dactyli blunt (fig. 20N). Pleon fused into single piece, without any pleopods; lateral margins straight, without any notches or incisions. Posterior margin of pleon with pair of fingerlike uropodal rami, anal cone in median (fig. 20M).

EтYмology: The specific name, caudatus, refers to the female bearing a pair of distinct, forked, fingerlike uropods.

Host AND Locality: Infesting Alpheus microstylus (Bate, 1888) (Alpheidae), Xisha (Paracel Islands), China.

REMARKs: The female of the new species has a swollen brood pouch, seven pairs of pereopods on both sides, and the male has a fused pleon, indicating that the present specimens belong to Eophrixus. The new species can be distinguished from the other 10 well-described species by its unique forked fingerlike uropods. Eophrixus caudatus, n. sp., is most closely related to E. shojii Shiino, 1941, but the new species differs from E. shojii as follows: (1) the first lateral plates of the new species are almost equal in size to the others, whereas the first lateral plates of $E$. shojii are much smaller than the others; (2) the female of the new species has prominent forked uropods while the uropods of $E$. shojii are small and globular; (3) the male of the new species lacks any indentation or notch on the pleon margin, but the male of E. shojii shows a distinct series of indentations indicating the pleomeres.

\section{Eophrixus shojii Shiino, 1941}

Eophrixus shojii Shiino, 1941: 155-156, figs. 1-2 [Japan, infesting Alpheus japonicus Miers, 1879]; Shiino, 1958: 71 [Japan, infesting Alpheus rapax Fabricius, 1798]; Danforth, 1963: 8; Markham, 1972: 48; Markham, 1982: 275, figs. 28-29 [Hong Kong, infesting Alpheus lobidens? De Haan, 1849]; Page, 1985: 185, 205-208, fig. 15 [New Zealand, infesting Alpheus socialis Heller, 1862]; Kim and Kwon, 1988: 199, 218-219, fig. 11 [Korea, infesting A. japonicus]; Markham, 1990: 555, 563 [Hong Kong, infesting Alpheus brevirostris (Olivier, 1811)]; Markham, 1991: 289, 294, fig.

3 [Thailand, infesting Alpheus sp.]; Markham, 1992a: 298; Kensley, 2001: 223; Li, 2003: 140, 154, 157; Liu, 2008: 692.

Anisarthrus shojii: Codreanu and Codreanu, 1956: 119; Codreanu, 1961: 138. Eophryxus [sic] shojii: Shiino, 1972: 9.

Material Examined: None.

Hosts and Localities: Infesting Alpheus brevirostris (Olivier, 1811), A. japonicus Miers, 1879, A. lobidens? De Haan, 1849, A. rapax Fabricius, 1798, A. socialis Heller, 1862, Alpheus sp. (Alpheidae), Japan, Korea, Hong Kong, Thailand, New Zealand.

\section{KEY TO 11 SPECIES OF EOPHRIXUS CAROLI, 1930, BASED ON MALE AND FEMALE CHARACTERS (E. ENCHOPHYLLUS AND E. LAEVIMANUS NOT INCLUDED IN THE KEY)}

1a. Female without uropods . . . . . . . . 2

1b. Female with uropods .......... 3

2a. Five pleomeres, exopods of pleopods well developed . . E. pikei (Bruce, 1968), n. comb.

2b. Four pleomeres, exopods of pleopods weakly developed .. E. kuboi (Shiino, 1939)

3a. Pereomeres I and II with serrate margins ... E. leptochelae (Pillai, 1966), n. comb.

3b. Pereomeres I and II with smooth margins 
4a. Uropods as slender rami ........... 5

4b. Uropods large, foliaceous .......... 6

5a. Lateral plates much larger than associated pleopods ............... 7

5b. Lateral plates nearly same size as associated pleopods ........ E. caudatus, n. sp.

6a. Male pleotelson with mediodistal bifurcation ........ E. subcaudalis (Hay, 1917)

6b. Male pleotelson elongate, entire ....... ......... E. yusakiensis (Shiino, 1934)

7a. Lateral plates of pleon globular ....... E. brevicauda (Chopra, 1923)

7b. Lateral plates of pleon plate shaped .... 8

8a. First pair of lateral plates much smaller than others ........ E. shoji Shiino, 1941

8b. Lateral plates subequal in size ........ 9

9a. Pereon with distinct pigment ......... ... . . . . E. nigrocinctus (Chopra, 1923)

9b. Pereon without pigment ......... 10

10a. Pleon with single small globular lobe terminally .......... E. lysmatae Caroli, 1930

10b. Pleon with a pair of globular uropods terminally ..... E. adriaticus (Nierstrasz and

Brender à Brandis, 1931)

\section{Hyperphrixus Nierstrasz and Brender à Brandis, 1931}

DiAgnosis (after Markham, 1985a): Female: Body axis distorted more than $90^{\circ}$, outline subcircular. Head deeply set into pereon, not bisecting any pereomeres; seven pereopods on concave side, clustered near head or evenly spaced between head and pleon; one or two pereopods on convex side. Five pleomeres, first four bearing well-developed, lanceolate, uniramous lateral plates and biramous pleopods; uropods lacking.

Male: Body more than three times as long as broad. Head and pereon separated. Sides of pereon subparallel; all pereomeres distinct but not deeply separated laterally. Pleon swollen, without traces of segmentation or appendages.

TyPe SPECIES: Hyperphrixus tattersalli Nierstrasz and Brender à Brandis, 1931, by monotypy.

OTHER SPECIES: Hyperphrixus castrensis Markham, 1985a; Hyperphrixus filiformis (Chopra, 1923)

\author{
Hyperphrixus filiformis (Chopra, 1923), \\ n. comb.
}

Hemiarthrus filiformis Chopra, 1923: 416, 428, 431, 435-438, text fig. 2, pl. 9, figs. 4-6 [Andaman Islands, infesting Alpheus paralcyone Coutière, 1905]; Chopra, 1930: 118; Monod, 1933: 244.

Hemiarthrus filiformis var. attenuata Chopra, 1923: 419, 428, 430, 431, 438-439, pl. 11, fig. 7 [Andaman Islands, infesting Alpheus paralcyone Coutière, 1905]; Chopra, 1930: 118-119; Monod, 1933: 244.

Phrixus (Paraphrixus) filiformis-Caroli, 1930: 259, 265.

Paraphrixus filiformis: Nierstrasz and Brender à Brandis, 1931: 205.

Hypophryxus filiformis: Markham, 1992a: 293-295, fig. 15-16 [Hong Kong, infesting Alpheus malleodigitus (Bate, 1888)]; Kensley, 2001: 224; Li, 2003: 140, 158.

Eophrixus filiformis: Kensley, 2001: 223.

Material Examined: None.

Hosts and Localities: Infesting Alpheus paralcyone Coutière, 1905, and Alpheus malleodigitus (Bate, 1888) (Alpheidae), Andaman Islands and Hong Kong.

Remarks: Markham (1992a) synonymized Hemiarthrus filiformis var. attenuata with the nominal species, but erroneously placed it into Hypophryxus (see Remarks under Eophrixus above).

Sigyn, n. gen.

Diagnosis: Female: Head highly distorted, embedded in pereon. Seven pereopods on both sides, but crowded together on short side. First two pereopods of long side near head, third on brood pouch located opposite head, other four pereopods of long side crowded together near pleon. Pleon of five segments, first four with lateral plates and uniramous pleopods. Pleon produced into a pedunculated globe, surface covered with small tubercules.

Male: Head fused with first pereomere, eyes present. Pereomeres distinct. Pleon without segmentation or appendages.

Eтymology: The name Sigyn ("victorious girlfriend" in Old Norse) calls attention to the closely related genus Loki Markham, 
1972; Sigyn is the wife of Loki in Norse mythology; gender feminine.

Sigyn branchialis, n. sp.

Figures 21C, D, 22, 23

Eophrixus branchialis An, 2006: 174, fig. 89 (unavailable name).

Material Examined: Infesting Alpheus digitalis De Haan, 1844, holotype o (CIEAL 920301), Sanya, $18^{\circ} 14^{\prime}$ N, $109^{\circ} 30^{\prime}$ E, 23 March 1992. Allotype ơ (CIEAL920301b), same locality as holotype. Female bopyrid parasiting right branchial chamber of host (fig. 21C, D).

DesCriPTION: Holotype female (CIEAL 920301a): Length $4.67 \mathrm{~mm}$ (including brood pouch), head length $0.67 \mathrm{~mm}$, head width $0.67 \mathrm{~mm}$. pereon length $0.78 \mathrm{~mm}$ (fig. 22A, B). Head length equal to width, eyes absent (fig. 22A). Head with frontal lamina. Only a single pair of antennae of five articles present (fig. 22C). Maxilliped with much larger anterior article, without palp, plectron highly blunted and not visible as distinct structure (fig. 22D). Barbula (fig. 22E) not located at exact bottom of maxilliped, inclines left, with seven to eight acute lobes on margin. First pereomere concealed by head, only visible lateral to head. Second to seventh pereomeres distinct only on short side (fig. 22A). Brood pouch large and completely closed (fig. 22B). Oostegite 1 (fig. 22F-I) with distinct asymmetry, left side much larger than right side. Oostegite 1 of left side (fig. 22F, G) with nearly smooth internal ridge, posterolateral point long and sharp, directed laterally. Oostegite of right side (fig. $22 \mathrm{H}, \mathrm{I}$ ) with smooth internal ridge, posterolateral point blunt and posteriorly directed. First two pereopods of long side near head, third pereopod attached to ventral surface of brood pouch, opposite head (fig. 22B). Fourth to seventh pleopods crowded near pleon (fig. 22B). All pereopods of short side arranged in a line (fig. 22A). Pereopods of same size and structure, with long bases and blunt dactyli (fig. 22J, K).

Pleon of five pleomeres, first four pleomeres bearing uniramous flaplike pleopods and lateral plates. Fifth pleomere a bulging sphere, surface covered with tubercles (fig. 22L).

Description: Allotype male (CIEA920302): Length $1.64 \mathrm{~mm}$, maximal width (across pereomere 4) $0.52 \mathrm{~mm}$, head length 0.16 $\mathrm{mm}$, head width $0.36 \mathrm{~mm}$, pleon length 0.44 $\mathrm{mm}$. All pereon segments distinct (fig. $22 \mathrm{M}$, 23A). Allotype attached at pereon/pleon boundary of holotype. Body elongate, sides nearly parallel except for rounded head and posterior abdomen (fig. 22M). Head subovate, wider than long, fused with pereomere 1. Small dark eyes near posterolateral corners (fig. 22M). Antennule of three articles, terminally setose (fig. 23C). Antenna of five articles, much longer than antennule, terminal two articles setose (fig. 22B). Pereomeres subequal in width, with truncate and setose margins (fig. 23D). All pereopods with similar structure and proportions, carpi and meri fused (fig. 23D, E). Flap-shaped scales with serrated edges on surface of ischia, meri, and carpi (fig. 23D, F). Propodi with many flap-shaped scales embedded in dactyli (fig. 23E), scale surfaces not smooth but covered with microscales (fig. 23G). Pereon without midventral projections, but with many setae on ventral surface of pereon (fig. 23H). Pleon fused into single piece, without pleopods or uropods, terminally setose (fig. 23J).

ETymology: The specific name, branchialis, refers to the type specimens found in the branchial chamber of the host.

Host and Locality: Infesting Alpheus digitalis De Haan, 1844 (Alpheidae), Hainan Province, China.

REMARKs: The present specimens parasitize a caridean shrimp host, the female has a swollen brood pouch formed by the oostegites from one side of the body, asymmetrical oostegite 1, a highly distorted body, and the male has a fused pleon; therefore this species belongs to Hemiarthrinae. However, no genera in this subfamily described to date are known to infest the branchial chamber of their host shrimps. Most hemiarthrine species are ventral abdominal parasites, but a few are found parasitizing other parts of the shrimp hosts, such as the dorsal pleon (Filophryxus dorsalis Bruce, 1972b), or even embedded in the mouthparts (Orophryxus shiinoi, Bruce, 1972a). The closest position of a hemiarthrine species on a host to that found with Sigyn branchialis, n. gen., n. sp., is seen with Metaphrixus intutus Bruce, 1966, which is positioned over the host branchial chamber and is attached underneath a raised flange 


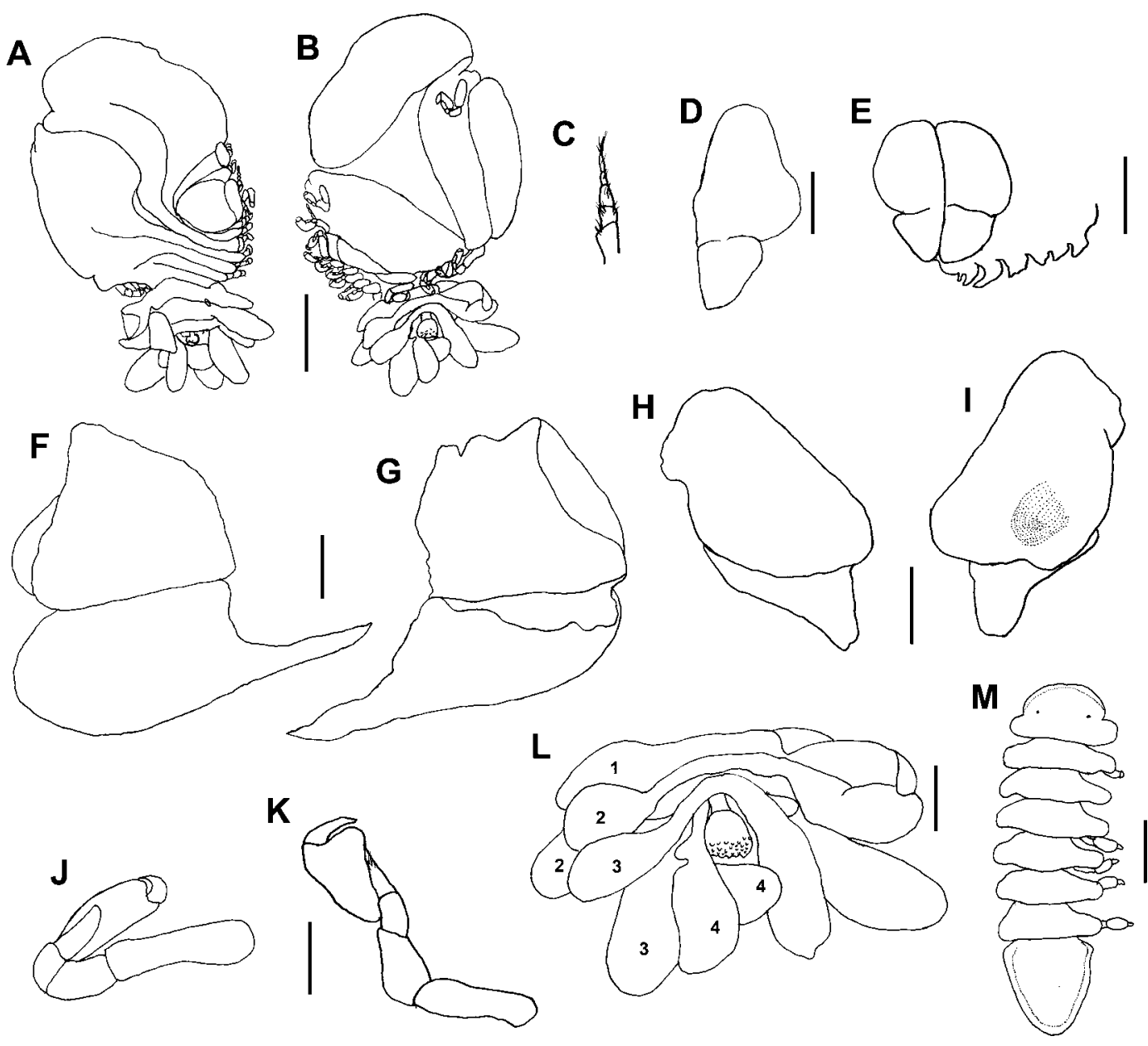

Fig. 22. Sigyn branchialis n. gen., n. sp., holotype female (CIEAL920301a) (A-L): A. Dorsal view. B. Ventral view. C. Right antenna. D. Right maxilliped. E. Barbula and maxilliped. F. Left oostegite 1, external view. G. Left oostegite 1, internal view. H. Right oostegite 1, external view. I. Right oostegite 1, internal view. J. Left pereopod 4. K. Left pereopod 7. L. Ventral view of the pleon. Allotype male (CIEAL920301b) (M): M. Dorsal view. Scale: $1 \mathrm{~mm}$ (A, B); $0.15 \mathrm{~mm}$ (C, D); $0.35 \mathrm{~mm}$ (E); $0.25 \mathrm{~mm}$ (F, G, $\mathrm{K}) ; 0.20 \mathrm{~mm}$ (H-J); $0.4 \mathrm{~mm}$ (L); $0.3 \mathrm{~mm}(\mathrm{M})$.

derived from the first abdominal pleuron of the host. The branchial mode of parasitism is considered to be the ancestral condition for bopyrids (see Boyko et al., 2013) and Sigyn branchialis, n. gen., n. sp., with its branchial position and full complement of pereopods on both sides of the female body may represent the most primitive hemiarthrine known to date.

The present specimens differ sufficiently from other hemiarthrine genera and deserve generic status. The new genus is most closely related to Loki Markham, 1972, Eophrixus Caroli, 1930, Anisarthrus Giard, 1907, and Cataphryxus Shiino, 1936. Sigyn, n. gen., can be distinguished from those four genera by its mode of parasitism within the branchial chamber, female with uniramous pleopods and globular terminal pleomere, and male with fused pleon lacking any lateral notches or appendages. The differences are summarized in table 2. Additionally, the fourth pleopod of the female has a tubercle that may indicate an endopodite (fig. 22L). 

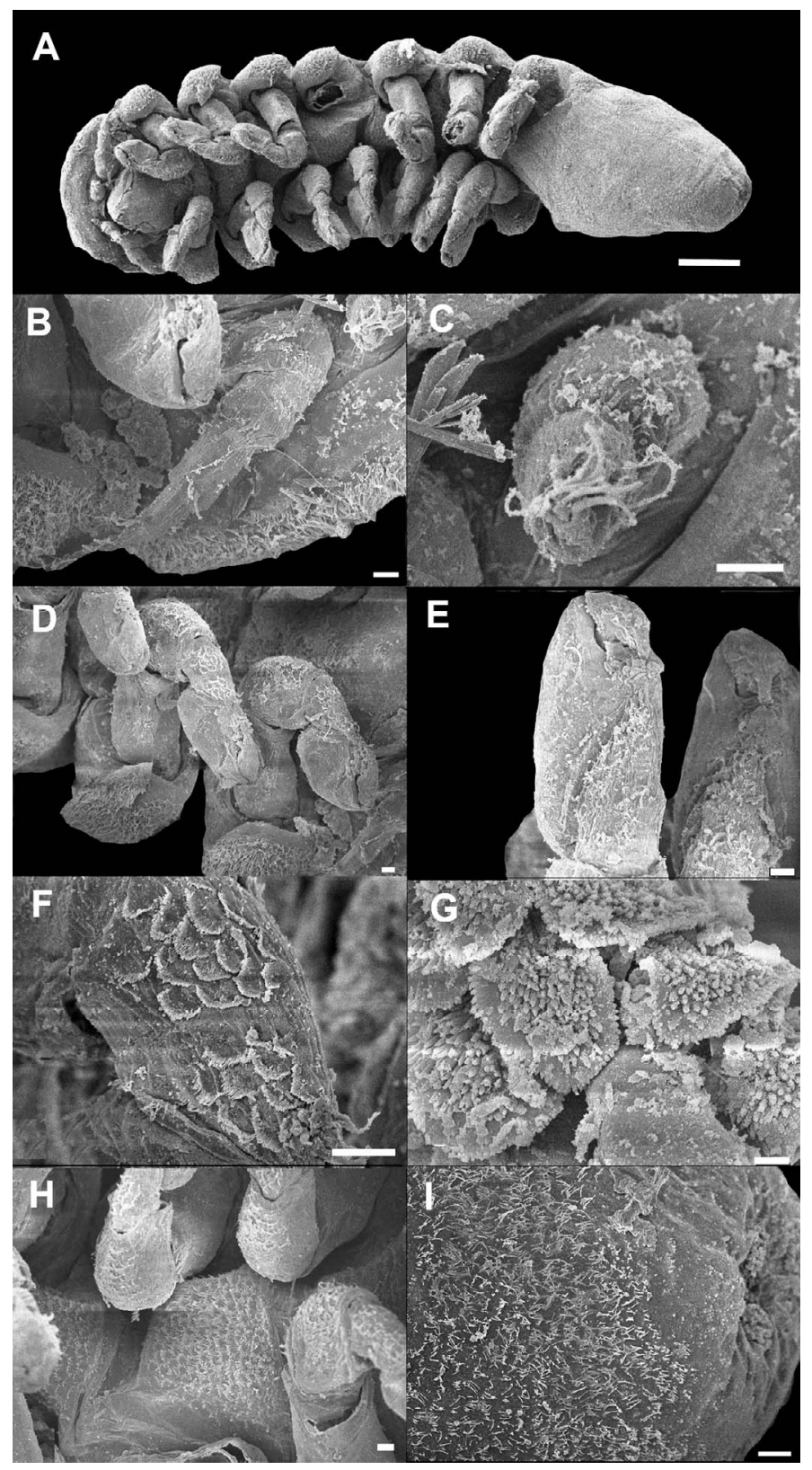

Fig. 23. Sigyn branchialis, n. gen., n. sp., SEM image of male (CIEAL920301b) (A-J): A. Ventral view. B. Left antenna. C. Right antennule. D. First right three pereopods. E. Right pereopods 6, 7. F. Carpi and meri of left pereopod 2. G. Propodus of left pereopod 2. H. Ventral surface of pereopod 3. I. Terminal edge of pleon. Scale: $100 \mu \mathrm{m}(\mathrm{A}) ; 10 \mu \mathrm{m}(\mathrm{B}-\mathrm{F}, \mathrm{H}, \mathrm{I}) ; 1 \mu \mathrm{m}(\mathrm{G})$.

There are two saclike organisms parasitizing the abdomen of the host shrimp (fig. 21C). The more anterior specimen is a shriveled sac with a distinct mantle opening, indicating that it is a rhizocephalan. The posterior specimen also appears to be a rhizocephalan, is ovate and filled with eggs, but there is no mantle pore. It is unclear whether 
TABLE 2

Comparison of Sigyn n. gen. with Four Other Closely Related Hemiarthrine Genera

\begin{tabular}{|c|c|c|c|c|c|c|}
\hline & Characters & Sigyn & Loki & Eophrixus & Cataphryxus & Anisarthrus \\
\hline \multirow[t]{5}{*}{ Female } & Parasite mode & Branchial & Abdominal & Abdominal & Abdominal & Abdominal \\
\hline & Lateral plates & 4 pairs & 3 pairs & 4 pairs & 4 pairs & 4 pairs \\
\hline & Pleopods & Uniramous & Uniramous & Biramous & Biramous & Uniramous \\
\hline & Number of pleopods & 7 & $\begin{array}{l}6 \text { (absent on } \\
\text { pleomere } 4)\end{array}$ & 7 & 7 & 7 \\
\hline & Uropods & Absent & Fork-shaped & Globular & Absent & Absent \\
\hline \multirow[t]{6}{*}{ Male } & Eyes & Small & Absent & Small & Absent & Large \\
\hline & Head and pereon & Fused & Fused & Fused & Separated & Fused \\
\hline & Pereomeres & Distinct & Fused medially & Distinct & Distinct & Distinct \\
\hline & Pereon and pleon & Separated & Fused & Separated & Separated & Separated \\
\hline & Pleomeres & Fused & Fused & $\begin{array}{l}\text { Defined } \\
\text { laterally }\end{array}$ & Fused & Fused \\
\hline & $\begin{array}{l}\text { Pleotelson posterior } \\
\text { margin }\end{array}$ & Smooth & Anal tube & Anal tube & Smooth & Anal tube \\
\hline
\end{tabular}

these represent two species or different stages of development of female externae of the same species. The only rhizocephalans known from alpheids are members of Thylacoplethus Coutière, 1902 (Cirripedia: Rhizocephala: Akentrogonida), but neither of these belongs to that genus.

\section{ACKNOWLEDGMENTS}

The first and second authors contributed equally to this publication. This study was supported by the National Natural Science Youth Foundation (no. 31101614) and National Natural Science Foundation (no. 31471970). We are indebted to all collectors from IOCAS in 1950s and 1989-1991. Thanks to Masayuki Osawa (Shimane University) for identification of Allorbimorphus tuberculus.

\section{REFERENCES}

Adkison, D.L. 1988. Pseudione parviramus and Aporobopyrus collardi, two new species of Bopyridae (Isopoda: Epicaridea) from the Gulf of Mexico. Proceedings of the Biological Society of Washington 101: 576-584.

Adkison, D.L., R.W. Heard, and G.T. Clark. 1982. Description of the male and notes on the female of Argeiopsis inhacae (Crustacea: Isopoda: Bopyridae). Proceedings of the Biological Society of Washington 95: 334-337.

Ahyong, S.T. 2006. [Crustacea: Galatheidae, Polychelidae, and Glyphocrangonidae (squatlobsters, blind, deep-sea lobsters and deepwater shrimps)]. In Explore lost worlds of the deep NORFANZ Voyage (chapter 3.1, results, taxonomy): 48-83. Final
Report to the Department of Environments and Heritage (Australia's National Oceans Office). Online resource (http://www.environment.gov.au/ apps/coasts/discovery/publications/norfanz-voyagereport.html).

An, J.-M. 2006. Study on the taxonomy and zoogeography of the family Bopyridae (Crustacea: Isopoda) in the China Seas [sic]. Ph.D. dissertation, Institute of Oceanology of Chinese Academy of Sciences, vii $+225 \mathrm{pp}$.

An, J. 2009. A review of bopyrid isopods infesting crabs from China. Integrative and Comparative Biology 49: 95-105.

An, J. 2011. Taxonomy of parasitic isopods from China. Beijing: Science Press.

An, J., H. Yu, and X.-Z. Li. 2006a. Description of a new genus and two new species of Ioninae (Isopoda: Epicaridea: Bopyridae) parasites of Leucosiidae (Decapoda: Brachyura) from Beibu Gulf. Zootaxa 1186: 57-68.

An, J., H. Yu, and X.-Z. Li. 2006b. A review of the genus Apocepon Nierstrasz and Brender à Brandis, 1930 (Isopoda: Epicaridea: Bopyridae) from Chinese waters, with description of a new species and a new record species. Zootaxa 1199: 1-17.

An, J., H. Yu, and X.-Z. Li. 2007a. One new record genus of Bopyridae (Crustacea, Isopoda, Epicaridea) from China. Acta Zootaxonomica Sinica 32: 1002-1003.

An, J., H. Yu, and J.D. Williams. 2007b. Four new records and a new species of Dactylokepon Stebbing, 1910 (Epicaridea: Bopyridae: Ioninae) from Chinese waters. Journal of Natural History 41: 2063-2079.

An, J., H. Yu, and X.-Z. Li. 2008. Subfamily Argeiinae (Crustacea, Isopoda, Epicaridea) from China. Acta Zootaxonomica Sinica 33: 225-226.

An, J., J.D. Williams, and H. Yu. 2009a. The Bopyridae (Crustacea: Isopoda) parasitic on thalassinideans 
(Crustacea: Decapoda) from China. Proceedings of the Biological Society of Washington 122: 225-246.

An, J., H. Yu, and J.C. Markham. 2009b. First record of the genus Gigantione (Epicaridea: Bopyridae: Pseudioninae) from Chinese waters, with descriptions of three new species. Journal of Natural History 43 : 335-353.

An, J., J.C. Markham, and H. Yu. 2010. Description of two new species and a new genus of bopyrid isopod parasites (Bopyridae: Pseudioninae) of hermit crabs from China. Journal of Natural History 44: 2065-2073.

An, J., J.D. Williams, and H. Yu. 2011. Three abdominal parasitic isopods (Isopoda: Epicaridea: Bopyridae: Athelginae) on hermit crabs from China and Hong Kong. Journal of Natural History 45: 2901-2913.

An, J., C.B. Boyko, and X.-Z. Li. 2012a. Two new species of the genus Megacepon George, 1947 (Crustacea: Isopoda: Bopyridae) infesting Varunidae (Crustacea: Brachyura: Grapsoidea) from China. Journal of Natural History 46: 131-143.

An, J., H. Yu, and C.B. Boyko. 2012b. A review of the genus Scyracepon Tattersall, 1905 (Crustacea: Isopoda: Bopyridae), with description of a new species from China. Journal of Natural History 46: 2889-2895.

An, J., H. Yu, and J.D. Williams. 2012c. A new species of Cancricepon Giard and Bonnier, 1887 (Isopoda: Bopyridae) from China. Systematic Parasitology 83: 243-248.

An, J., X.-Q. Zhang, and X.-Z. Li. 2012d. A new species of Bopyridae (Crustacea, Isopoda, Epicaridea) infesting Porcellana sp. Acta Zootaxonomica Sinica 37: 722-725.

An, J., C.B. Boyko, and X.-Z. Li. 2013a. A new genus and species of parasitic isopod (Isopoda: Bopyridae: Orbioninae) from Chinese waters, with a new locality and host record for Orbione halipori Nierstrasz and Brender à Brandis, 1923. Systematic Parasitology 84: 149-156.

An, J., C.B. Boyko, and X.-Z. Li. 2013b. A review of the genus Parapenaeonella (Isopoda: Bopyridae: Orbioninae), with description of a new species from Chinese waters and synonymy of Parapenaeonella lamellata Bourdon, 1979. Journal of Natural History 47: 2633-2648.

An, J., C.B. Boyko, and X.-Z. Li. 2013c.A new species and two new records of Minicopenaeon Bourdon, 1981 (Crustacea: Isopoda: Bopyridae) from China. Systematic Parasitology 85: 255-262.

An, J., X. Li, and J.C. Markham. 2013d. Three isopod parasites (Bopyridae: Pseudioninae), including two new species, of hermit crabs from the South China Sea. Raffles Bulletin of Zoology 61: 561-569.

An, J., C.B. Boyko, and X.-Z. Li. 2014a. Review of the parasitic genus Epipenaeon Nobili, 1906 (Crustacea: Isopoda: Bopyridae), with new records and redescription of four species from China. Journal of Natural History 48: 2027-2048.
An, J., X. Niu, J.C. Markham, and W. Jiang, 2014b. A review of the genus Rhopalione Pérez, 1920 (Crustacea: Isopoda: Bopyridae), with first record of the male and parasitic mode of $R$. sinensis Markham, 1990 from China. Chinese Journal of Oceanology and Limnology. 32: 1-4.

Baer, J.G. 1946. Le parasitisme. Lausanne: F. Rouge et Cie, 232 pp.

Baer, J.G. 1951. Ecology of animal parasites. Urbana: University of Illinois Press, $\mathrm{x}+224 \mathrm{pp}$.

Barnard, K.H. 1940. Contributions to the crustacean fauna of South Africa. XII. Further additions to the Tanaidacea, Isopoda, and Amphipoda, together with keys for the identification of the hitherto recorded marine and fresh-water species. Annals of the South African Museum 32: 381-543.

Barnard, K.H. 1955. Additions to the fauna-list of South African Crustacea and Pycnogonida. Annals of the South African Museum 43: 1-107.

Bate, C.S. 1864. Characters of new species of crustaceans discovered by J.K. Lord on the coast of Vancouver Island. Proceedings of the Zoological Society of London 1864: 661-668.

Bate, C.S. 1888. Report on the Crustacea Macrura dredged by H.M.S. Challenger during the years 1873-1876. Reports on the Scientific results of the voyage of H.M.S. Challenger during the years 187376. Zoology 24: i-xc, 1-918, 927-942, pls. 1-148.

Beck, J.T. 1980. Life history relationships between the bopyrid isopod Probopyrus pandalicola and one of its freshwater shrimp hosts Palaemonetes paludosus. American Midland Naturalist 104: 135-154.

Bonnier, J. 1900. Contribution à l'étude des épicarides. Les Bopyridae. Travaux de la Station Zoologique de Wimereux 8: 1-476, pls. 1-41.

Bourdon, R. 1967a. Sur trois nouveaux Bopyridae du Sénégal. Bulletin de l'Institut Fondamental d'Afrique Noire, sér. A 29: 107-122.

Bourdon, R. 1967b. Sur deux nouveaux épicarides (Isopoda) parasites de crustacés décapodes. Zoologische Mededelingen 42: 167-174.

Bourdon, R. 1967c. Sur quelques nouvelles espèces de Cabiropsidae (Isopoda Epicaridea). Bulletin du Muséum National d'Histoire Naturelle (2nd série) 38: 846-868.

Bourdon, R. 1968. Les Bopyridae des mers européennes. Mémoires du Muséum National d'Histoire Naturelle (Série A) Zoologie 50: 77-424.

Bourdon, R. 1972a. Epicaridea de Java, Ile Maurice et Afrique du Sud (Crustacea, Isopoda). Steenstrupia 2:105-119.

Bourdon, R. 1972b. Sur quelques Bopyridae (Crustacea, Isopoda) parasites de galathéides. Bulletin du Muséum National d'Histoire Naturelle (3e sér.) 66: 817-838.

Bourdon, R. 1979a. Épicarides de Madagascar. II. Bulletin du Muséum National d'Histoire Naturelle (4e sér.) 1 (A): 471-506. 
Bourdon, R. 1979b. Sur la taxonomie et l'éthologie de quelques orbioninés (Isopoda Epicaridea). Internationale Revue der Gesammte Hydrobiologie 64: 425-435.

Bourdon, R. 1979c. Bopyridae de la campagne Biaçores (Isopoda Epicaridea). Bulletin du Muséum National d'Histoire Naturelle 4e sér. 1 (A): 507-512.

Bourdon, R. 1980a. Les espèces du genre Bopyrella J. Bonnier (Crustacea, Isopoda, Bopyridae). Bulletin du Muséum National d'Histoire Naturelle (4e sér.) 2 (A): 185-236.

Bourdon, R. 1980b. Aporobopyrus dollfusi n. sp. (Crustacea, Epicaridea, Bopyridae) parasite de porcellanes de la Mer Rouge. Bulletin du Muséum National d'Histoire Naturelle (4e sér.) 2 (A): 237-244.

Bourdon, R. 1981. Crustacés isopodes. I. Bopyridae parasites des Pénéides. Résultats des Campagnes MUSORSTOM. I. Philippines (18-28 Mars 1976), vol. 1 (10). Mémoires d'ORSTOM 91: 237-260.

Bourdon, R. 1982. Sur deux nouveaux isopodes épicarides du genre Bopyrella Bonnier. Internationale Revue der Gesammte Hydrobiologie 67: 749-756.

Bourdon, R. 1983. Expédition Rumphius II (1975). Crustacés parasites, commensaux, etc. (Th. Monod éd.). VIII. Crustacés isopodes (3e partie: épicarides Bopyridae). Bulletin du Muséum National d'Histoire Naturelle (4e sér.) 5 (A): 845-869.

Bourdon, R. 1987. Suborder Epicaridea. In E.N. Kozloff (editor), Marine invertebrates of the Pacific Northwest: 341-344. Seattle: University of Washington Press.

Bourdon, R., and C.B. Boyko. 2005. Redescription of Bopyrophryxus branchiabdominalis Codreanu, 1965 (Crustacea: Isopoda: Bopyridae) with a reappraisal of the subfamily Bopyrophryxinae Codreau, 1965. Proceedings of the Biological Society of Washington 118: 108-116.

Bourdon, R., and A. J. Bruce. 1979. Bopyrella saronae sp. nov., a new bopyrid parasite (Isopoda) of the shrimp Saron marmoratus (Olivier). Crustaceana 37: 191-197.

Bourdon, R., and A.J. Bruce. 1983. Six bopyrid shrimp parasites (Isopoda, Epicaridea) new to the Australian fauna. Crustaceana 45: 96-106.

Bourdon, R. and J.C. Markham. 1980. A new genus and species of bopyrid isopod infesting alpheid shrimps of the genus Synalpheus in the western Atlantic Ocean. Zoologische Mededelingen 55: 221-230.

Bourdon, R., and J.H. Stock. 1979. On some IndoWest Pacific Bopyridae (Isopoda, Epicaridea) in the collections of the Zoölogisch Museum, Amsterdam. Beaufortia 28: 205-218.

Bourdon, R., J.-L. d'Hondt, and A. Veillet. 1981. Note préliminaire sur les microsètes et les «fentes céphaliques» chez les bopyriens (crustacés épicarides).
Bulletin de la Societé Zoologique de France 105: 495-504.

Bowman, T. E. 1956. Una especie nueva de Bopyrella (Crustacea: Isopoda) de los Roques, Venezuela. Novedades Cientificas Contribuciones Occasionales del Museo de Historia Natural La Salle, Serie Zoológica 19: 1-4.

Boyko, C.B. 2004. The Bopyridae (Crustacea: Isopoda) of Taiwan. Zoological Studies 43: 677-703.

Boyko, C.B. 2006. A new shrimp host for Parabopyrella lata (Nierstrasz and Brender à Brandis, 1929) (Crustacea: Isopoda: Bopyridae) from the Florida gulf coast: a novel host/parasite relationship or a case of mistaken identity? Gulf of Mexico Science 24: $41-44$.

Boyko, C.B. 2014. Bopyrinae Rafinesque, 1815. In M. Schotte et al. (editors), World marine, freshwater and terrestrial isopod crustaceans database. World Register of Marine Species. Online resource (http://www. marinespecies.org/aphia.php? $\mathrm{p}=$ taxdetailsandid $=$ 589329 on 2014-04-07).

Boyko, C.B., and J.D. Williams 2010. A new genus and species of primitive bopyrid (Isopoda, Bopyridae) parasitizing hermit crabs (Anomura) from deep waters in the eastern Atlantic and Japan. In C.H.J. M. Fransen, S. De Grave, and P.K.L. Ng (editors), Studies on Malocostraca, Lipke Bijdeley Holthuis memorial vol. (Crustacean Monographs 14): 145157. Leiden: Brill.

Boyko, C.B., J. Moss, J.D. Williams, and J.D. Shields. 2013. A molecular phylogeny of Bopyroidea and Cryptoniscoidea (Crustacea: Isopoda). Systematics and Biodiversity 11: 495-506.

Bruce, A. J. 1966. An interesting new phrixid (Epicaridea) parasitic on a pontoniinid shrimp. Annals and Magazine of Natural History, 13th ser. 8: 385-390.

Bruce, A. J. 1972a. Orophryxus shiinoi gen nov., sp, nov., an unusual phryxid (Crustacea, Isopoda, Bopyridae) parasitic upon a pontoniid shrimp from Zanzibar. Parasitology 64: 445-450.

Bruce, A. J. 1972b. Filophryxus dorsalis gen. nov., sp. nov., an unusual bopyrid parasite frorn eastern Australia. Parasitology 65: 351-358.

Bruce, A.J. 1968. A new species of Hypophryxus (Isopoda, Bopyridae) from an Indo-Pacific pontoniid shrimp. Crustaceana 14: 13-20.

Bruce, A.J. 1982. The pontoniine shrimp fauna of Hong Kong. In B. Morton and C.K. Tseng (editors), Proceedings of the First International Marine Biological Workshop: the marine flora and fauna of Hong Kong and southern China, Hong Kong, 1980: 233-284. Hong Kong: Hong Kong University Press.

Bruce, A.J. 1990. Redescriptions of five Hong Kong carideans first described by William Stimpson, 1860. In B. Morton (editor), Proceedings of the Second International Marine Biological Workshop: the marine flora and fauna of Hong Kong and Southern 
China, Hong Kong, 1986: 569-610. Hong Kong: Hong Kong University Press.

Brusca, R.C., and G.D.F. Wilson. 1991. A phylogenetic analysis of the Isopoda with some classificatory recommendations. Memoirs of the Queensland Museum 31: 143-204.

Brusca, R.C., V.R. Coelho, and S. Taiti. 2001. A guide to the coastal isopods of California. Online resource (http://tolweb.org/notes/?note_id=3004).

Calman, W.T. 1898. On a collection of Crustacea from Puget Sound. Annals of the New York Academy of Sciences 11: 259-292, pls. 31-34.

Campos, E., and A.R. De Campos. 1989. Epicarideos de Baja California: distribución y notas ecológicas de Probopyrus pandalicola (Packard, 1879) en el Pacífico oriental. Revista de Biologa Tropical 37: 29-36.

Caroli, E. 1930. Notizia di tre specie nuove ed una poco nota di bopiridi addominali, parassiti di caridei del golfo di Napoli (contributo alla conoscenza del genere Phrixus Rathke). Bollettino della Società Naturalisti in Napoli 41: 258-269, pl. 9.

Caroli, E. 1949. Breve rassegna dei bopiridi addominali parassiti di caridei. Pubblicazioni della Stazione Zoologica di Napoli 21: 232-235.

Cericola, M.J., and J.D. Williams. 2015. Prevalence, reproduction and morphology of the parasitic isopod Athelges takanoshimensis Ishii, 1914 (Isopoda: Bopyridae) from Hong Kong hermit crabs. Marine Biology Research 11: 236-252.

Chace, F.A., Jr. 1984. The caridean shrimps (Crustacea: Decapoda) of the Albatross Philippine Expedition, 1907-1910, part 2: families Glyphocrangonidae and Crangonidae. Smithsonian Contributions to Zoology 397: i-iv, 1-63.

Chaplin-Ebanks, S.A., and M.C. Curran. 2007. Prevalence of the bopyrid isopod Probopyrus pandalicola in the grass shrimp, Palaemonetes pugio, in four tidal creeks on the South Carolina-Georgia coast. Journal of Parasitology 93: 73-77.

Chopra, B. 1922. Preliminary note on Isopoda of the family Bopyridae parasitic on Indian Decapoda Macrura. Journal and Proceedings of the Asiatic Society of Bengal, New Series 18: 69-71.

Chopra, B. 1923. Bopyrid isopods parasitic on Indian Decapoda Macrura. Records of the Indian Museum 25: 411-550, pls. 11-21.

Chopra, B. 1927. Bopyrid isopods. Bulletin of the Madras Government Museum, New Series, Natural History Section 1: 119-122.

Chopra, B. 1930. Further notes on bopyrid isopods parasitic on Indian Decapoda Macrura. Records of the Indian Museum 32: 113-147, pls. 4-6.

Codreanu, R. 1961. Crustacei paraziti cu afinitati indopacifice în Marea Neagra. Hidrobiologia 3: 133-146. [in Romanian]

Codreanu, R. 1967. Clasificarea evolutiva a bopirienilor, isopode parazite ale crustaceelor decapode si importanta lor biologica generala. Studii si Cercetari de Biologie Seria Zoologie 19: 203-211.

Codreanu, M., and R. Codreanu. 1956. Sur l'Anisarthrus pelseneeri, épicaride parasite abdominal de la crevette Athanas nitescens; sa présence dans la Mer Noire et la dispersion du genre Anisarthrus. Bulletin Biologique de la France et de la Belgique 90: 111-121.

Cornalia, E., and P. Panceri. 1861. Osservazioni zoologiche ed anatomiche sopra un nuovo genere di isopodi sedentarii (Gyge branchialis). Memorie delle Reale Accademia delle Scienze di Torino (ser. 2) 19: 85-118, pls. 1-2.

Coutière, H. 1902. Sur un nouveau de rhizocéphale, parasite des Alpheidae. Comptes Rendus Hebdomadaires des Séances de l'Académie de Sciences 134: 913-915.

Dana J.D. 1852. Crustacea, part I. United States Exploring Expedition during the years 1838-42 under the command of Ch. Wilkes U.S.N. 13: i-viii + 1-685. Philadelphia: C. Sherman.

Dana, J.D. 1855. Atlas Crustacea. United States Exploring Expedition, during the years 1838, 1839, 1840, 1841, 1842. Under the command of Charles Wilkes, U.S.N.. Philadelphia: C. Sherman.

Danforth, C.G. 1963. Bopyridian (Crustacea, Isopoda) parasites found in the eastern Pacific of the United States. Ph.D. dissertation, Oregon State University, Corvallis.

Danforth, C.G. 1970. Epicaridea (Crustacea: Isopoda) of North America. Ann Arbor, MI: University Microfilms, ii + 1-191, pls. 1-48.

Danforth, C.G. 1971a. Two bopyrids (Isopoda) from New Guinea. Bulletin of the Southern California Academy of Sciences 70: 99-102.

Danforth, C.G. 1971b. New bopyrids (Isopoda) from the Indian and Pacific Oceans. Micronesica 7: 163-177.

De Grave, S., and C.H.J.M. Fransen. 2011. Carideorum catalogus: the Recent species of the dendrobranchiate, stenopodidean, procarididean and caridean shrimps (Crustacea: Decapoda). Zoologische Mededelingen 85: 195-589.

de Man, J.G. 1913. The Decapoda of the Siboga Expedition. Part II. Family Alpheidae. Siboga Expeditie Monographie 39al: 113-465.

Duan J., J. An, and H. Yu, 2008. A new species and two new record species of genus Allokepon Markham, 1982 (Isopoda: Epicaridea: Bopyridae) from China. Zootaxa 1682: 62-68.

Dumbauld, B., J. Chapman, M. Torchin, and A. Kuris. 2011. Is the collapse of mud shrimp (Upogebia pugettensis) populations along the Pacific Coast of North America caused by outbreaks of a previously unknown bopyrid isopod parasite (Orthione griffe$n i s)$ ? Estuaries and Coasts 34: 336-350.

Espinosa-Pérez, M.D.C., and M.E. Hendrickx. 2001. Checklist of isopods (Crustacea: Peracarida: Isopoda) from the eastern tropical Pacific. Belgian Journal of Zoology 131: 43-55. 
Espinosa-Pérez, M.D.C., and M.E. Hendrickx. 2006. A comparative analysis of biodiversity and distribution of shallow-water marine isopods (Crustacea: Isopoda) from polar and temperate waters in the East Pacific. Belgian Journal of Zoology 136: 219-247.

Espinosa-Pérez, M.D. C., M.E. Hendrickx, and J.J. Morrone. 2009. Identification of generalized tracks for the species of Isopoda (Peracarida) from the eastern Pacific. Journal of Crustacean Biology 29: 224-231.

Faxon, W. 1895. Reports on an exploration off the west coasts of Mexico, Central and South America, and off the Galapagos Islands, in charge of Alexander Agassiz, by the U.S. Fish Commission Steamer "Albatross" during 1891, Lieut.-Commander Z.L. Tanner, U.S.N., commanding. XV. The stalk-eyed Crustacea. Memoirs of the Museum of Comparative Zoölogy at Harvard College 18: 1-292, pls. A-K, 1-56, 1 map.

Fee, A.R. 1927. The Isopoda of Departure Bay and vicinity, with descriptions of new species, variations and colour notes. Contributions to Canadian Biology and Fisheries (New Series) 3: 13-46, 1 pl.

Feeney, T.D. 1995. Physical controls on the distribution of contaminants on Sturgeon Bank, Fraser River Delta, British Columbia. Master of Science thesis, University of British Columbia, Vancouver.

Fraser, C.M. 1932. A comparison of the marine fauna of the Nanaimo region with that of the San Juan Archipelago. Transactions of the Royal Society of Canada (3rd series) 26: 49-70.

George, M.J., and J.-O. Strömberg. 1968. Some new species and new records of marine isopods from San Juan Archipelago, Washington, U.S.A. Crustaceana 14: 225-254.

George, P.C. 1947. Megacepon choprai, gen. et sp. nov., a bopyrid isopod from the gill chamber of Sesarma tetragonum (Fabr.). Records of the Indian Museum 44: 385-390.

Gerstaecker, A. 1901. Die Klassen und Ordnungen der Arthropoden wissenschaftlich dargestellt in Wort und Bild. Band 5, Abtheilung 2. Crustacea (Zweite Hälfte: Malacostraca). Leipzig: C.F. Winter'sche Verlagshandlung, i-viii + 1-1319, pls. 1-128.

Giard, A. 1907. Sur l'Anisarthrus pelseneeri (nov. gen. et nov. sp.) bopyrien parasite d'Athanas nitescens Leach et sur la synonymie du genre Hemiarthrus. Comptes Rendus Hebdomadaires des Séances et Mémoires de la Société de Biologie 63: 321-324.

Giard, A., and J. Bonnier. 1887. Contributions a l'étude des bopyriens. Traveaux de l'Institut Zoologique de Lille et du Laboratoire de Zoologie Maritime de Wimereux 5: 1-272, pls. 1-10.

Giard, A., and J. Bonnier. 1888. Sur quelques espèces nouvelles de céponiens. Comptes Rendus Hebdomadaires des Séances de l'Académie de Sciences 107: 4447.

Giard, A., and J. Bonnier. 1890. Prodrome d'une monographie des épicarides du Golfe de Naples.
Bulletin Scientifique de la France et de la Belgique 22: 367-391.

Gifford, J. 1934. The life history of Argeia pauperata From Crago franciscorum. Master's thesis, Stanford University, Stanford, 21 pp. 2 tables, 1 chart, 5 pls.

Gurjanova, E., 1936a. Faune de l'URSS. Crustaces. Vol. 7, no. 3, isopodes des mers orientales. Institut Zoologique de l'Academie des Sciences de l'URSS 6, vii +278 pp.; figs. 1-150. [in Russian with German summary]

Gurjanova, E. 1936b. Beiträge zur Kenntnis der Isopodenfauna des Pazifischen Ozeans. IV. Neue Isopodenarten aus dem Japanischen und Beringmeer. Zoologischer Anzeiger 114: 250-265.

Han, Q., and X. Li. 2007. An account of the Glyphocrangon shrimps (Decapoda, Caridea) in the collections of the Institute of Oceanology, Chinese Academy of Sciences. Crustaceana 80: 545-553.

Han, Q.-X., and X.-Z. Li. 2010. Records of the Crangonidae (Crustacea, Decapoda, Caridea) species from the Yellow Sea and Bohai Sea. Acta Zootaxonomica Sinica 35: 227-239.

Hansen, H.J. 1897. Reports on the dredging operations off the west coast of Central America to the Galapagos, to the west coast of Mexico, and in the Gulf of California, in charge of Alexander Agassiz, carried on by the U.S. Fish Commission Steamer "Albatross," during 1891, Lieut. Commander Z.L. Tanner, U.S.N., commanding. XXII. The Isopoda. Bulletin of the Museum of Comparative Zoölogy at Harvard College 31: 95-129, pls. 1-6, 1 map.

Hatch, M.H. 1947. The Chelifera and Isopoda of Washington and adjacent regions. University of Washington Publications in Biology 10: 155-274.

Hay, W. P. 1917. A new genus and three new species of parasitic isopod crustaceans. Proceedings of the United States National Museum 51: 569-574, pls. 98-100.

Hesse, C. E. 1865. Recherches sur les crustacés rares ou nouveaux des cotes de France (complément du troisième article). Annales des Sciences Naturelles, Zoologie, sér. 5 3: 221-242, pl. 4.

Hiraiwa, Y.K. 1933. Studies on a bopyrid, Epipenaeon japonica Thielemann. I. Morphological studies in both sexes. Journal of Science of the Hiroshima University (Ser. B.) Div. 1 (Zoology) 2 (4): 49-70, pl. 1.

Høeg, J.T., and A.V. Rybakov. 1992. Revision of the Rhizocephala Akentrogonida (Cirripedia), with a list of all the species and a key to the identification of families. Journal of Crustacean Biology 12: 600-609.

Holthuis, L.B. 1971. Biological results of the University of Miami Deep-Sea Expeditions. 75. The Atlantic shrimps of the deep-sea genus Glyphocrangon A. Milne Edwards, 1881. Bulletin of Marine Science 21: $267-373$. 
International Commission on Zoological Nomenclature (ICZN). 1999. International code of zoological nomenclature. 4th ed. London: International Trust for Zoological Nomenclature.

Ishii, S. 1914. On a new epicaridean isopod (Athelges takanoshimensis sp. nov.) from Eupagurus samuelis Stimp. Annotationes Zoologicae Japonenses 8: 519530, pl. 7.

Jay, C.V. 1985. Life history relationships between the parasitic isopod Argeia pugettensis (Epicaridea: Bopyridae) and its host shrimp Crangon franciscorum (Caridea: Crangonidae). M.A. thesis, Humboldt State University, Arcata, California.

Jay, C.V. 1989. Prevalence, size and fecundity of the parasitic isopod Argeia pugettensis on its host shrimp Crangon francisorum (sic). American Midland Naturalist 121: 68-77.

Kannupandi, T. 1976. A study on the cuticle of Stegoalpheon kempi Chopra (Isopoda: Crustacea) in relation to its parasitic mode of life. Journal of Experimental Marine Biology and Ecology 25: 87-94.

Kaufmann, R.S., W.W. Wakefield, and A. Genin. 1989. Distribution of epibenthic mega fauna and lebensspuren on two central North Pacific seamounts. Deep Sea Research 36: 1863-1896.

Kazmi, Q. B., and R. Bourdon. 1997. A new bopyrid isopod Progebiophilus assisi on the mud shrimp Upogebia (U.) assisi Barnard (Thalassinoidea) from Pakistan. Pakistan Journal of Marine Sciences 61/ 62: 59-67.

Kazmi, Q. B., M. Schotte, and F. Yousuf. 2002. An illustrated key to the Malacostraca (Crustacea) of the northern Arabian Sea, part V: Isopoda. Pakistan Journal of Marine Sciences 2: 47-116.

Kensley, B. 1968. Pseudione elongata africana, a new subspecies of bopyrid isopod from the west coast of the Cape Peninsula, South Africa. Crustaceana 15: 188-192.

Kensley, B. 1974. Bopyrid Isopoda from southern Africa. Crustaceana 26: 259-266.

Kensley, B. 2001. Biogeography of the marine Isopoda of the Indian Ocean, with a check-list of species and records. In B. Kensley and R.C. Brusca (editors), Crustacean Issues 13. Isopod systematics and evolution: 205-264. Rotterdam: Balkema.

Kensley, B., and T.-Y. Chan. 2001. Two species of deep-sea flabelliferan isopods from Taiwan (Crustacea: Peracarida: Aegidae, Anuropidae). Journal of Natural History 35: 481-496.

Kim, H.S., and D.-H. Kwon. 1988. Bopyrid isopods parasitic on decapod crustaceans in Korea. Korean Journal of Systematic Zoology Special Issue 2: 199-221.

Kossmann, R. 1881. Studien über Bopyriden. Zeitschrift für Wissenschaftliche Zoologie 35: 652-665, pls. 32-35.

Kozloff, E.N. 1974. Keys to the marine invertebrates of Puget Sound, the Strait of Georgia, and the San Juan
Archipelago, and adjacent regions. Seattle: University of Washington Press, $\mathrm{x}+226 \mathrm{pp}$.

Kröyer, H. 1838a. Grönlands Amfipoder. Det Kongelige Danske Videnskabernes Selskabs Naturvidenskabelige og Mathematiske Afhandlinger, series 4 (7): 229-326, pls. 1-4.

Kröyer, H. 1838b. Grönlands Amfipoder. Copenhagen: Bianco Lunos. [Separately paginated reprinting of Kröyer, 1838a.]

Kruczynski, W.L., and R.J. Menzies. 1977. Taxonomic status of Synsynella Hay and Bopyro Pearse (Isopoda: Bopyridae). Proceedings of the Biological Society of Washington 89: 551-558.

Latreille, P. A. 1802. Histoire Naturelle Genrale et Particulière, des Crustacés et des Insectes. F. Dufart, Paris.

Leija-Tristán, A., and S.I. Salazar-Vallejo. 1991. Parasitismo de Progebiophilus bruscai (Isopoda: Bopyridae) sobre el camarón Upogebia dawsoni (Thalassinoidea: Upogebiidae), en Baja California Sur, México. Revista de Biología Tropical 39: 1-5.

Lemos de Castro, A. 1970. Crustáceos isópodos epicarídeos do Brasil. V. Duas espécies novas de hiperparasitas pertencentes ao gênero Cabirops Kossmann (Isopoda, Cabiropsidae). Boletim do Museu Nacional (Nova Série) Zoologia 277: 1-7, pls. 1-4.

Li, L. 2003. Hong Kong's isopods. In B. Morton (editor), Perspectives on marine environmental change in Hong Kong and southern China, 1977-2001. Proceedings of an International Workshop Reunion Conference, Hong Kong 21-26 October 2001: 137166. Hong Kong: Hong Kong University Press.

Li, X., and T.-Y. Chan. 2014. Pandalid shrimps (Crustacea, Decapoda, Caridea) collected from the Philippines PANGLAO 2005 deep-sea expedition. Mémoires du Muséum National d'Histoire Naturelle 204: 129-154.

Liu, R.E. (editor). 2008. Checklist of marine biota of China seas. Beijing: Science Press, 1267 pp.

MacGinitie, G.E., and N. Macginitie, 1949. Natural history of marine animals. New York: McGrawHill, xii + 473 pp.; 282 figs.

MacGinitie, G.E., and N. Macginitie, 1968. Natural history of marine animals. 2nd ed. New York: McGraw-Hill, xii + 523 pp.; 286 figs.

Marin Jarrin, J.R. 2007. The ecology of surf zone fauna of dissipative sandy beaches in southern Oregon, U.S.A. Master of Science thesis, University of Oregon, Eugene.

Marin Jarrin, J.R., and A.L. Shanks. 2008. Ecology of a population of Lissocrangon stylirostris (Caridea: Crangonidae), with notes on the occurrence and biology of its parasite, Argeia pugettensis (Isopoda: Bopyridae). Journal of Crustacean Biology 28: 613-621.

Marin Jarrin, J.R., and A.L. Shanks. 2011. Spatio-temporal dynamics of the surf-zone faunal assemblages at a southern Oregon sandy beach. Marine Ecology 32: $232-242$. 
Markham, J.C. 1972. Two new genera of western Atlantic abdominally parasitizing Bopyridae (Isopoda, Epicaridea), with a proposed new name for their subfamily. Crustaceana Supplement 3: 39-56.

Markham, J.C. 1975. New records of two species of parasitic isopods of the bopyrid subfamily Ioninae in the western Atlantic. Crustaceana 29: 55-67.

Markham, J.C. 1977. Description of a new western Atlantic species of Argeia Dana with a proposed new subfamily for this and related genera (Crustacea, Isopoda, Bopyridae). Zoologische Mededelingen 52: 107-123.

Markham, J.C. 1979. A new genus and species of bopyrid isopod infesting the crangonid shrimp Pontophilus abyssi Smith in deep water of the northwestern Atlantic Ocean. Proceedings of the Biological Society of Washington 92: 769-772.

Markham, J. C. 1980. A new species of Dicropleon and new records of three other species of bopyrid isopods from the Indian Ocean. Bulletin of Marine Science 30: 623-633.

Markham, J.C. 1982. Bopyrid isopods parasitic on decapod crustaceans in Hong Kong and Southern China. In B. Morton and C.K. Tseng (editors), Proceedings of the First International Marine Biological Workshop: the marine flora and fauna of Hong Kong and southern China, Hong Kong, 1980: 325391. Hong Kong: Hong Kong University Press.

Markham, J.C. 1985a. A review of the bopyrid isopods infesting caridean shrimps in the northwestern Atlantic Ocean, with special reference to those collected during the Hourglass Cruises in the Gulf of Mexico. Memoirs of the Hourglass Cruises 8: 1-156.

Markham, J.C. 1985b. Additions to the bopyrid isopod fauna of Thailand. Zoologische Verhandelingen 224: $1-63$.

Markham, J.C. 1986. Evolution and zoogeography of the Isopoda Bopyridae, parasites of Crustacea Decapoda. In R.H. Gore and K.L. Heck (editors), Crustacean Issues 4. Crustacean biogeography: 143-164. Rotterdam: A.A. Balkema.

Markham, J.C. 1988. Descriptions and revisions of some species of Isopoda Bopyridae of the north western Atlantic Ocean. Zoologische Verhandelingen 246: $1-63$.

Markham, J. C. 1989. Three species of Isopoda Bopyridae new to the fauna of the Philippines. The Beagle, Records of the Northern Territory Museum of Arts and Sciences 6: 141-148.

Markham, J.C. 1990. Further notes on the Isopoda Bopyridae of Hong Kong. In B. Morton (editor), Proceedings of the Second International Marine Biological Workshop: the marine flora and fauna of Hong Kong and Southern China, Hong Kong, 1986: 555568. Hong Kong: Hong Kong University Press.

Markham, J.C. 1991. Redescriptions and new records of Isopoda Bopyridae (Crustacea) from Thailand. Raffles Bulletin of Zoology 39: 289-297.
Markham, J.C. 1992a. Second list of additions to the Isopoda Bopyridae of Hong Kong. In B. Morton (editor), The marine flora and fauna of Hong Kong and southern China III. Proceedings of the Fourth International Marine Biological Workshop: the marine flora and fauna of Hong Kong and southern China, Hong Kong, 11-29 April 1989: 277-302. Hong Kong: Hong Kong University Press.

Markham, J.C. 1992b. The Isopoda Bopyridae of the eastern Pacific - missing or just hiding? Proceedings of the San Diego Society of Natural History 17: 1-4.

Markham, J.C. 1995. Two new species of Isopoda Bopyridae (Crustacea) infesting thalassinideans in the western Pacific. Raffles Bulletin of Zoology 43: 83-89.

Markham, J.C. 2004. New species and records of Bopyridae (Crustacea: Isopoda) infesting species of the genus Upogebia (Crustacea: Decapoda: Upogebiidae): the genera Orthione Markham, 1988, and Gyge Cornalia and Panceri, 1861. Proceedings of the Biological Society of Washington 117: 186-198.

Markham, J.C. 2010. The isopod parasites (Crustacea: Isopoda: Bopyridae) of decapod Crustacea of Queensland, Australia, with descriptions of three new species. In P.J.F. Davie and J.A. Phillips (editors), Proceedings of the 13th International Marine Biological Workshop, Marine Fauna and Flora of Moreton Bay, Queensland. Memoirs of the Queensland Museum-Nature 54: 151-197.

Markham, J.C., and C.B. Boyko. 2003. A new species of Albunione Markham \& Boyko, 1999 (Crustacea: Isopoda: Bopyridae: Pseudioninae) from Taiwan. American Museum Novitates 3410: 1-7.

Martin, J.W., and G.E. Davis. 2001. An updated classification of the recent Crustacea. Natural History Museum of Los Angeles County Science Series 39: $1-124$.

Menzies, R.J., and M.A. Miller, 1954. Key to the Chelifera and the suborders of the Isopoda. In S.F. Light (editor), Intertidal invertebrates of the central California Coast: 138-159. Berkeley: University of California Press.

Miller, M.A. 1975. Phylum Arthropoda: Crustacea, Tanaidacea and Isopoda. In R.I. Smith and J.T. Carlton (editors), Light's manual: intertidal invertebrates of the central California coast: 277-312. Berkeley: University of California Press, xviii + 716 pp.

Miya, Y. 1972. The Alpheidae (Crustacea, Decapoda) of Japan and its adjacent waters. Part I. Publications of the Amakusa Marine Biological Laboratory 3: 23-101.

Monod, T. 1933. Mission Robert-Ph. Dollfus en Égypte. Tanaidacea et Isopoda. Mémoires Présentés à l'Institut d'Égypte 21: 161-264.

Monod, T. 1976. Sur une nouvelle collection de Crustacés Decapodes de Nouméa (Nouvelle Calédonie). Cahiers du Pacifique 19: 133-152.

Moore, J.A., et al. 2003. Biodiveristy of Bear Seamount, New England Seamount Chain: results of exploratory trawling. Journal of Northwestern Atlantic Fishery Science 31: 363-372. 
Morton, B. 2003. Hong Kong's international malacological wetland and marine biological workshops (1977-1998): changing local attitudes towards marine conservation. In B. Morton (editor), Perspectives on marine environmental change in Hong Kong and southern China, 1977-2001. Proceedings of an International Workshop Reunion Conference, Hong Kong 21-26 October 2001: 31-71. Hong Kong: Hong Kong University Press.

Nakashima, Y. 1995. Can small male shrimps achieve copulation in the presence of larger ones? Journal of Ethology 13: 9-16.

Nelson, S.G., M.A. Simmons, and A.W. Knight. 1986. The energy burden of the bopyrid parasite Argeia pauperata (Crustacea, Isopoda) on the grass shrimp Crangon franciscorum (Crustacea, Crangonidae). Comparative Biochemistry and Physiology 83A: 121-124.

Nierstrasz, H.F., and G.A. Brender à Brandis. 1923. Die Isopoden der Siboga-Expedition. II. Isopoda Genuina. I. Epicaridea. Siboga-Expeditie 32b: 57121, pls. 4-9.

Nierstrasz, H.F., and G.A. Brender à Brandis. 1925. Bijdragen tot de kennis der fauna van Curaçao. Resultaten eener reis van Dr. C.J. van der Horst in 1920. Epicaridea. Bijdragen tot de Dierkunde 24: $1-8$, pl. 1.

Nierstrasz, H.F., and G.A. Brender à Brandis. 1929. Papers from Dr. Th. Mortensen's Pacific Expedition 1914-16. XLVIII. Epicaridea. I. Videnskabelige Meddedelser fra den Dansk Naturhistoriske Forening i København 87: 1-44.

Nierstrasz, H.F., and G.A. Brender à Brandis. 1930. Résultats scientifiques du voyage aux Indes orientales néerlandaises de LL. AA. RR. le Prince et la Princesse Léopold de Belgique. Isopoda Epicaridea. Mémoires du Musée Royal d'Histoire Naturelle de Belgique, Hors Série 3: 12-17.

Nierstrasz, H.F., and G.A. Brender à Brandis. 1931. Papers from Dr. Th. Mortensen's Pacific Expedition 1914-16. LVII. Epicaridea II. Videnskabelige Meddedelser fra den Dansk Naturhistoriske Forening i København 91: 147-226, pl. 1.

Nierstrasz, H.F., and G.A. Brender à Brandis. 1932. Alte und neue Epicaridea. Zoologischer Anzeiger 101: 90-100.

Nobili, G. 1905. Decapodi e isopodi della Nuova Guinea Tedesca raccolti dal Sign. L. Biró. Annales Historico-Naturales Musei Nationalis Hungarici 3: 480-507, pls. 12-13.

Nobili, G. 1906. Nuovi bopiridi. Atti della Real Accademia della Scienze di Torino 41: 1098-1113, pl. 1.

Norman, A. M. 1905. Museum normanianum, or a catalogue of the Invertebrata of the Arctic and North Atlantic temperate ocean and Palaerctic Region, which are contained in the collection of the Rev. Canon A. M. Norman, M. A., D. C. L., LL. D., F.
R. S., F. L. S., \&c. III. Crustacea Second Edition. Durham: Thos. Caldcleugh \& Son.

Oguro, C. 1961. On the neurosecretory system of two parasitic isopods, Argeia pugettensis Dana and Athelges japonicus Shiino. Annotationes Zoologicae Japonenses 34: 43-48.

Page, R.D.M. 1985. Review of the New Zealand Bopyridae (Crustacea: Isopoda: Epicaridea). New Zealand Journal of Zoology 12: 185-212.

Pearse, A.S. 1930. Parasites of Fukien crabs. Proceedings of the Natural History Society of Fukien Christian University 3: 10-18.

Pearse, A.S. 1953. Parasitic crustaceans from Alligator Harbor, Florida. Quarterly Journal of the Florida Academy of Sciences 15: 187-243.

Penha-Lopes, G., J.F. Marques, M.C. Leal, A.F. Carvalho, and J. Paula. 2013. Population structure and reproduction of Pseudione elongata africana (Bopyridae, Isopoda). Western Indian Ocean Journal of Marine Science 11: 27-39.

Pillai, N.K. 1954. A preliminary note on the Tanaidacea and Isopoda of Travancore. Bulletin of the Central Research Institute, University of Travancore (series C, Natural Sciences) 3: 1-21.

Pillai, N.K. 1966. Isopod parasites of south Indian crustaceans. Crustaceana 10: 183-191.

Poore, G.C.B., J.C. Markham, and H.M. Lew Tan 2002. Superfamily: Bopyroidea. In W.W.K. Houston and P.L. Beesley (editors), Zoological catalogue of Australia, vol. 19.2A. Crustacea: Malacostraca: Syncarida, Peracarida: Isopoda, Tanaidacea, Mictacea, Thermosbaenacea, Spelaeogriphacea: 111-137. Melbourne: CSIRO Publishing.

Qazi, M.H. 1959. Some bopyrid isopods of West Pakistan. Scientist (Scientific Society of Pakistan) 3: 5562, 2 unnumbered pls.

Rafinesque, C. S. 1815. Analyse de la nature ou tableau de l'univers et des corps organisés. Palerme.

Rao, K.S.P.B., and T.N.C. Ramaprasad. 1964. A note on Stegoalpheon kempi Chopra. Current Science 33: 588-589.

Restivo, F. 1971. Su di una nuova specie di Cabirops parassita di Pseudione. Pubblicazioni della Stazione Zoologica di Napoli 39: 70-86.

Restivo, F. 1975. Nuovi dati su Paracabirops (n.d. Cabirops) marsupialis Caroli, parassita di Gyge branchialis. Pubblicazione della Stazione Zoologica di Napoli 39: 150-168.

Richard, J. 1900. Essai sur les crustacés considérés dans leurs rapports avec l'hygiène, la médicine et la parasitologie. Lille: Bigot Frères.

Richardson, H. 1899a. Key to the isopods of the Pacific coast of North America, with descriptions of 22 new species. Proceedings of the United States National Museum 21: 815-869.

Richardson, H. 1899b. Key to the isopods of the Pacific coast of North America, with descriptions of 22 new 
species. Annals and Magazine of Natural History, ser. 7, 4: 321-338.

Richardson, H. 1900. Synopses of North-American Invertebrates. VIII. The Isopoda. - Part II. Asellota, Oniscoidea, Epicaridea. American Naturalist 34: $295-309$.

Richardson, H. 1904a. Contributions to the natural history of the Isopoda. Proceedings of the United States National Museum 27: 1-89.

Richardson, H. 1904b. A reply to certain criticisms of Prof. Alfred Giard respecting the bopyrids. Comptes Rendus Hebdomadaires des Séances et Mémoires de la Société de Biologie 56: 856-858.

Richardson, H. 1905a. Isopods from the Alaska Salmon Investigation. Bulletin of the Bureau of Fisheries 24: 209-221.

Richardson, H. 1905b. A monograph on the isopods of North America. Bulletin of the United States National Museum 54: i-liii, 1-727.

Richardson, H. 1909. Isopods collected in the northwest Pacific by the U.S. Bureau of Fisheries Steamer "Albatross" in 1906. Proceedings of the United States National Museum 37: 75-129.

Richardson, H. 1910. Marine isopods collected in the Philippines by the U.S. Fisheries steamer Albatross in 1907-8. Bureau of Fisheries Document 736: 1-44.

Ricketts, E.F., and J. Calvin. 1939. Between Pacific tides. Stanford, CA: Stanford University Press, xxii +320 pp.; 112 figs.

Ricketts, E.F., and J. Calvin. 1948. Between Pacific tides. Revised ed. Stanford, CA: Stanford University Press, xxvii +365 pp.; 129 figs; frontispiece.

Ricketts, E.F., and J. Calvin. 1952. Between Pacific tides. 3rd ed. Stanford, CA: Stanford University Press, xiii +501 pp.; 132 figs.; 46 plates; 2 unnumbered maps; 9 unnumbered plates.

Ricketts, E.F., and J. Calvin, 1968. Between Pacific tides. 4th ed, revised by Joel W. Hedgpeth. Stanford, CA: Stanford University Press, xiv $+614 \mathrm{pp}$.

Ricketts, E.F., J. Calvin and J.W. Hedgpeth. 1985. Between Pacific tides. 5th ed., revised by David W. Phillips. Stanford: Stanford University Press, vii + $652 \mathrm{pp}$.

Risso, A. 1816. Histoire Naturelle des Crustacés des Environs de Nice. Librairie Grecque-Latine-Allemande, Paris.

Román-Conteras, R. 2008. Chapter 5. Estudios y registros de isópodos epicarideos en México: 18972005. In F. Álvarez Noguera and G.A. Rodríguez Almaraz (editors), Crustáceos de México: Estado Actual de su Conocimiento: 81-114. Monterrey, Mexico: Biblioteca Universitaria Raúl Rangel Frías.

Román-Contreras, R., and L.A. Soto. 2002. A new deep-water genus and species of a branchial bopyrid infesting the galatheid crab Munidopsis erinaceus from the southwestern Gulf of Mexico. Journal of Crustacean Biology 27: 370-379.
Romero-Rodríguez, J., and R. Román-Contreras. 2008. Aspects of the reproduction of Bopyrinella thorii (Richardson, 1904) (Isopoda, Bopyridae), a branchial parasite of Thor floridanus Kingsley, 1878 (Decapoda, Hippolytidae) in Bahía de la Ascensión, Mexican Caribbean. Crustaceana 81: 1201-1210.

Romero-Rodríguez, J., and R. Román-Conteras. 2014. Relationships of the branchial parasite Bopyrinella thorii (Isopoda, Bopyridae) and its host Thor floridanus (Decapoda, Hippolytidae). Crustaceana 87: 463-475.

Rudy, J., P., and L.H. Rudy. 1979. Oregon Estuarine invertebrates: an illustrated guide to the common and important invertebrate animals. Portland, OR: U.S. Fish and Wildlife Service.

Rudy, P., and L. Rudy. 2013. Oregon estuarine invertebrates. 2nd ed. University of Oregon, Eugene. Available online (https://library.uoregon.edu/scilib/oimb/oei).

Rybakov, A.V. 1990. Bourdonia tridentata gen. n., sp. n. (Isopoda: Cabiropsidae) a hyperparasite of Bopyroides hippolytes Kroyer [sic] from the shrimp Pandalus borealis. Parazitologiia 24: 408-416.

Rybakov, A.V., and V.V. Avdeev. 1991. Two Bopyroides species (Isopoda, Bopyridae) from the fareastern shrimps. Parazitologiia 25: 167-172.

Saito, N., G. Itani, and N. Nunomura. 2000. A preliminary checklist of isopod crustaceans of Japan. Bulletin of the Toyama Science Museum 23: 11-107.

Sadog lu, P. 1969. Variations in eye degeneration and pigment in some parasitic isopods during their life cycle. Pubblicazione della Stazione Zoologica di Napoli 37: 173-209.

Salazar-Vallejo, S.I., and A. Leija-Tristán. 1990. Progebiophilus bruscai $\mathrm{n}$. sp., a new bopyrid isopod parasitic on the mud shrimp, Upogebia dawsoni Williams (Thalassinoidea), from the Gulf of California. Cahiers de Biologie Marine 30: 423-432.

Sars, G. O. 1883. Oversigt af Norges Crustaceer med foreløbige Bemaerkninger over de nye eller mindre bekjendte Arter. I. (Podophthalmata - Cumacea - Isopoda - Amphipoda). Forhandlinger i Videnskabs-Selskabet i Christiania for 1882: 1-124, pls. $1-6$.

Sassaman, C., G.A. Schultz, and R. Garthwaite. 1984. Host, synonymy, and parasitic incidence of Bopyrella calmani (Richardson) from central California (Isopoda: Epicaridea: Bopyridae). Proceedings of the Biological Society of Washington 97: 645-654.

Savant, K.B. 1973. A note on the first record of isopod parasite Bopyrella hogarti [sic] (Chopra) on west coast of India. Current Science 42: 330-331.

Schultz, G.A. 1969. How to know the marine isopod crustaceans. Dubuque, IA: Wm. C. Brown Company.

Scott, T. 1902. Notes on Scottish Crustacea. Annals and Magazine of Natural History, ser. 7 10: 1-5, pl. 1.

Seo, Y.S., C.-W. Oh, and A. Kim. 2014. Effect of the bopyrid isopod Argeia pugettensis on the growth and reproduction of the Kuro shrimp Argis lar. 
Korean Journal of Fisheries and Aquatic Science 47: $413-418$.

Sherman, M. B., and M.C. Curran. 2013. The effect of the bopyrid isopod Probopyrus pandalicola (Packard, 1879) (Isopoda, Bopyridae) on the survival time of the daggerblade grass shrimp Palaemonetes pugio Holthuis, 1949 (Decapoda, Palaemonidae) during starvation at two different temperatures. Crustaceana 86: 1328-1342.

Shields, J.D. 2001. CD-ROM Review [of] Goater, Timothy M. 1999, An Exploration of Marine Parasitic Crustacea. Journal of Crustacean Biology 21: 313-314.

Shiino, S.M. 1933. Bopyrids from Tanabe Bay. Memoirs of the College of Science, Kyoto Imperial University (ser. B) 8: 249-300.

Shiino, S.M. 1934. Bopyrids from Tanabe Bay II. Memoirs of the College of Science, Kyoto Imperial University (ser. B) 9: 257-287.

Shiino, S.M. 1936. Bopyrids from Tanabe Bay III. Memoirs of the College of Science, Kyoto Imperial University (ser. B) 11: 157-174.

Shiino, S.M. 1937a. Some additions to the bopyrid fauna of Japan. Annotationes Zoologicae Japonenses 16: 293-300.

Shiino, S.M. 1937b. Bopyrids from Tanabe Bay, IV. Memoirs of the College of Science, Kyoto Imperial University (ser. B) 12: 479-493.

Shiino, S.M. 1939. Bopyrids from Kyûsyû and Ryûkyû. Records of Oceanographic Works in Japan 10: 79-99.

Shiino, S.M. 1941. Further notes on bopyrids from Kyûsyû and Ryûkyû. Annotationes Zoologicae Japonenses 20: 154-158.

Shiino, S.M. 1949a. On two species of the bopyrid genus, Bopyrella, found in Japan. Bulletin of the Biogeographical Society of Japan 14: 45-50.

Shiino, S.M. 1949b. On two new genera of Bopyridae found in Japan. Bulletin of the Biogeographical Society of Japan 14: 57-63.

Shiino, S.M. 1950. Notes on some new bopyrids from Japan. Journal of Mie Medical College 1: 151-167.

Shiino, S.M. 1951. Some bopyrid parasites found on the decapod crustaceans from the waters along Mie Prefecture. Report of Faculty of Fisheries, Prefectural University of Mie 1: 26-40.

Shiino, S.M. 1952. Phylogeny of the family Bopyridae. Annual Report of the Prefectural University of Mie, section 2, Natural Science 1: 33-56.

Shiino, S.M. 1958. Note on the bopyrid fauna of Japan. Report of the Faculty of Fisheries, Prefectural University of Mie 3: 27-74, pl. 3.

Shiino, S. M. 1964. On three bopyrid isopods from California. Report of the Faculty of Fisheries, Prefectural University of Mie 5: 19-25.

Shiino, S.M. 1972. [The Epicaridea (list of species) from Japan]. Kansai Shizenkagaku 24: 7-10. [in Japanese]
Sindermann, C.J. 1970. Principal diseases of marine fish and shellfish. New York: Academic Press, x + 369 pp.

Sindermann, C.J. 1990. Principal diseases of marine fish and shellfish. 2nd ed. Vol. 2. London: Academic Press, xii +516 pp.

Sindermann, C.J., and A. Rosenfield. 1967. Principal diseases of commercially important marine bivalve Mollusca and Crustacea. United States Department of the Interior, Fish and Wildlife Service, Bureau of Commercial Fisheries, Fishery Bulletin 66: 335385, figs. $1-9$.

Stebbing, T.R.R. 1893. A history of Crustacea, Recent Malacostraca. London: Kegan Paul, Trench, Trübner and Co.

Stebbing, T.R.R. 1904. South African Crustacea. Part II. Marine Investigations in South Africa 2: 1-92, pls. 5-16.

Stebbing, T.R.R. 1908. South African Crustacea. Part IV. Annals of the South African Museum 6: 1-96, pls. 28-40.

Stebbing, T.R.R. 1910a. General catalogue of South African Crustacea (part 5 of S.A. Crustacea, for the Marine Investigations in South Africa). Annals of the South African Museum 6: 281-593, pls. 15-22.

Stebbing, T.R.R. 1910b. No. VI.-Isopoda from the Indian Ocean and British East Africa. Transactions of the Linnean Society of London, 2nd ser., Zoology 14: 83-122, pls. 5-11.

Stimpson, W. 1857. On the Crustacea and Echinodermata of the Pacific shores of North America. Boston Journal of Natural History 6: 444-532.

Stimpson, W. 1864. Descriptions of new species of marine Invertebrata from Puget Sound, collected by the naturalists of the North-West Boundary Commission, A.H. Campbell, Esq., Commissioner. Proceedings of the Academy of Natural Sciences of Philadelphia 1864: 153-161.

Stock, J.H. 1960. Notes on Epicaridea. Crustaceana 1: 28-33, pl. 1.

Strathmann, M.F. 1987. Phylum or Subphylum Crustacea class Malacostraca order Decapoda, Caridea. In M.F. Strathmann (editor), Reproduction and development of marine invertebrates of the northern Pacific Coast. Data and methods for the study of eggs, embryos, and larvae: 432-440. Seattle: University of Washington Press.

Strömberg, J.-O. 1971. Contribution to the embryology of bopyrid isopods with special reference to Bopyroides, Hemiarthrus and Peseudione (sic) (Isopoda, Epicaridea). Sarsia 47: 1-47.

Thielemann, M. 1910. Beitrage zur Naturgeschichte Ostasiens. Herausgegeben von Dr. F. Doflein. Beitrage zur Kenntnis der Isopodenfauna Ostasiens. Abhandlungen der mathematisch-physischen Klasse der Konigleichen Bayerischen Akademie von Wissenschaft Supplementarischer Band 2 (Abhandlung 3): 1-109, pls. 1-2. 
Trilles, J.-P. 1999. Ordre des isopodes sous-ordre des épicarides (Epicaridea Latreille, 1825). In J. Forest (editor), Traité de Zoologie. Anatomie, Systématique, Biologie (Pierre-P. Grassé). Tome VII, Fascicule III A, Crustacés Péracarides. Memoires de l'Institut Oceanographique 19: 279-352.

Wenner, E.L. 1978. Comparative biology of four species of glyphocrangonid and crangonid shrimp from the continental slope of the Middle Atlantic Bight. Canadian Journal of Zoology 56: 1052-1065.

Wicksten, M.K. 1979. New records of the species of Glyphocrangon in the northeastern Pacific Ocean (Caridea: Glyphocrangonidae). Proceedings of the Biological Society of Washington 92: 217-224.

Wicksten, M.K. 2008. Decapod Crustacea of the Californian and Oregonian zoogeographic provinces. Online resource (http://repositories.cdlib.org/sio/lib/ 26/). [This is the original publication; this document has been revised several times as an e-document with changes in page numbers, e.g., p. 164 in the 2008 version is p. 168 in the 2009 version]
Wicksten, M.K. 2012. Decapod Crustacea of the Californian and Oregonian zoogeographic provinces. Zootaxa 3371: 1-307.

Williams J.D. and J. An. 2009. The cryptogenic parasitic isopod Orthione griffenis Markham, 2004 from the east and west Pacific. Integrative and Comparative Biology 49: 1-13.

Williams, J.D., and C.B. Boyko. 2010. First description of the male of Eragia profunda Markham, 1994 (Crustacea: Isopoda: Bopyridae), with comments on relationships in the subfamily Argeiinae. Proceedings of the Biological Society of Washington 123: 149-152.

Williams, J.D., and C.B. Boyko. 2012. The global diversity of parasitic isopods associated with crustacean hosts (Isopoda: Bopyroidea and Cryptoniscoidea). PLoS ONE 7: e35350.

Yü, S.C. 1935. Notes on a bopyrid isopod parasitic on Crago crago cassiope de Man. Scientific Conference Nanning, Kwangsi Province, Aug. 11-15, 1935: 52-53. 